UNIVERSIDADE DE SÃO PAULO

FACULDADE DE FILOSOFIA, LETRAS E CIÊNCIAS HUMANAS DEPARTAMENTO DE LINGUÍSTICA

PROGRAMA DE PÓS-GRADUAÇÃO EM SEMIÓTICA E LINGUÍSTICA GERAL

JÉSSICA VIANA MENDES

\title{
Interações Modal-temporais no Português Brasileiro
}

Versão corrigida

São Paulo

2019 
LOMBADA

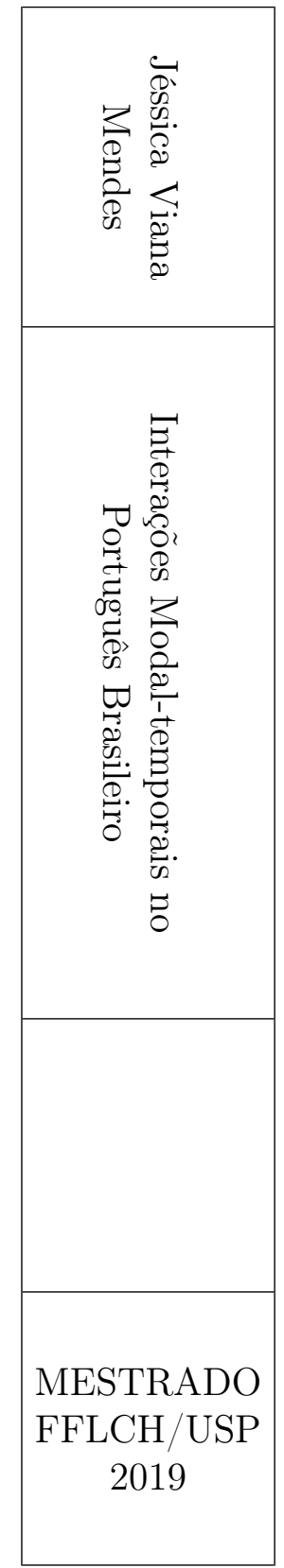




\title{
Interações Modal-temporais no Português Brasileiro
}

\author{
Versão original
}

Dissertação de mestrado apresentada ao Programa de Pós-graduação em Semiótica e Linguística Geral da Faculdade de Filosofia, Letras e Ciências Humanas da Universidade de São Paulo, como parte dos requisitos para obtenção do título de Mestre em Letras.

Orientador: Prof. Dr. Marcelo Barra Ferreira

São Paulo 


\section{ENTREGA DO EXEMPLAR CORRIGIDO DA DISSERTAÇÃO/TESE}

\section{Termo de Ciência e Concordância do (â)_orientador (a).}

Nome do (a) aluno (a): Jéssica Viana Mendes

Data da defesa: 25/02/2019

Nome do Prof. (a) orientador (a): Prof. Dr. Marcelo Barra Ferreira

Nos termos da legislação vigente, declaro ESTAR CIENTE do conteúdo deste EXEMPLAR CORRIGIDO elaborado em atenção às sugestões dos membros da comissão Julgadora na sessão de defesa do trabalho, manifestando-me plenamente favorável ao seu encaminhamento e publicação no Portal Digital de Teses da USP.

São Paulo, 22/04/2019

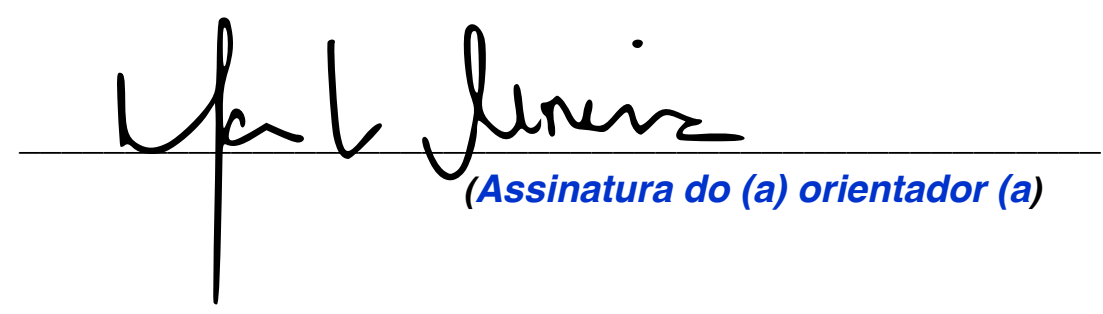


Autorizo a reprodução total ou parcial deste trabalho, por qualquer meio convencional ou eletrônico, para fins de estudo ou pesquisa, desde que citada a fonte.

Catalogação na publicação

Serviço de Biblioteca e Documentação

Faculdade de Filosofia, Letras e Ciências Humanas

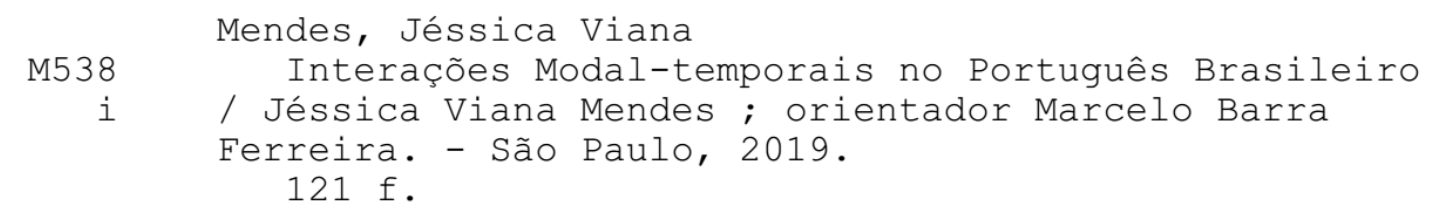


VIANA, J. M. Interações Modal-temporais no Português Brasileiro. Dissertação apresentada à faculdade de Filosofia, Letras e Ciências Humanas da Universidade de São Paulo para obtenção do título de mestre em Letras.

Aprovada em: 25/02/2019

\section{Banca examinadora}

Prof. Dr. Marcus Vinícius Lunguinho Julgamento:

Profa. Dra. Roberta Pires de Oliveira Julgamento:

Profa. Dra. Ana Lúcia de Paula Muller Julgamento:

Prof. Dr. Jairo Morais Nunes (suplente) Julgamento:

Profa. Dra. Ana Paula Quadros Gomes (suplente) Julgamento:

Profa. Dra. Luciana Sanchez Mendes (suplente)

Julgamento:
Instituição: UNB

Assinatura:

Instituição: UFSC

Assinatura:

Instituição: USP

Assinatura:

Instituição: USP

Assinatura:

Instituição: UFRJ

Assinatura:

Instituição: UFF

Assinatura: 
Ao Ivan,

minha entidade favorita neste mundo 


\section{AGRADECIMENTOS}

Como não poderia ser diferente, preciso agradecer em primeiro lugar ao Professor Marcelo Barra Ferreira, o melhor orientador que eu poderia ter tido. Foi lendo (e não entendendo nada sobre) seu trabalho no primeiro ano da faculdade que eu decidi estudar semântica formal. Eu poderia facilmente preencher uma dissertação inteira só com agradecimentos - pelos quatro cursos que fiz contigo, pelas inúmeras reuniões, pelo seu método tão único e criterioso de correção de escrita (que serve também como teste cardíaco), pelas máximas ${ }^{1}$, por conseguir identificar cálculos errados a metros de distância mas eu acho que não consigo escrever mais nada substancial pelas próximas semanas. Vou apenas dizer que se algum dia eu tiver um impacto tão grande na vida de alguém quanto você teve na minha, eu vou saber que eu fiz algo de muito certo. Se alguma coisa está certa nesta dissertação, sem dúvida foi culpa do Marcelo. Os erros foram pontos sobre os quais ele provavelmente tentou me alertar dezenas de vezes e eu não entendi as pistas.

Se tem uma coisa da qual eu não posso reclamar é da distribuição de eventos ao longo desse mestrado. Pude apresentar versões anteriores desse trabalho no CIEL VI, no CITAM I e no 3EISSI, e o feedback que recebi foi indispensável para o desenvolvimento dessa pesquisa. Organizar um evento deve ser extremamente trabalhoso, e eu sou muito grata aos organizadores dessas conferências: Marcus Lunguinho, Eloisa Pilati, Helena Guerra Vicente, Heloisa Maria Moreira Salles, Paulo Medeiros Junior, Rozana Reigota Naves (CIEL VI); Adriana Martins, Adriana Lessa, Fernanda de Carvalho Rodrigues e Marcus Lunguinho (de novo) (CITAM I); Roberta Pires de Oliveira, Sandra Quarezemin, Monica Monawar, Ana Maria Tramunt Ibaños e Ani Carla Marchesan (3EISSI). Agradecimento especial às organizadoras do 3EISSI pelo coffee break vegano ma-ra-vi-lho-so.

Esses eventos foram particularmente importantes por terem me colocado em contato com dois dos autores que tiveram a maior influência no meu trabalho até agora - Professor Kai von Fintel e Professora Angelika Kratzer. Agradeço imensamente aos dois pela generosidade com seu tempo, e a delicadeza e perspicácia com as quais discutiram meu trabalho.

A todos os professores do DL com os quais estudei nos quatro anos de faculdade, muito obrigada por serem tão inspiradores. Aos professores do DL que ministraram os cursos que fiz durante o mestrado (Professora Elaine Grolla, Professor Jairo Nunes, Professora

${ }^{1}$ Algumas das minhas favoritas:

(1) a. O papel pune.

b. A ambiguidade é a saída dos fracos.

c. Não existe almoço de graça. 
Janayna Carvalho, Professor Marcelo Ferreira, Professor Ezekiel Panitz, Professora Ana Müller), suas contribuições a este trabalho foram inestimáveis. Jana, obrigada por aguentar meus surtos com sintaxe.

Muito obrigada à Professora Ana Scher por ter supervisionado meu primeiro semestre como monitora na sua turma de Elementos da Linguística I. Aprendi tanto sobre comprometimento, profissionalismo e linguística com você que ainda não consigo nem dimensionar o impacto que aquela experiência teve na minha carreira. Ao Professor Alexander Cobbinah, obrigada pela experiência incrível de ser monitora das turmas de Língua não Indo-europeia. Seja bem-vindo ao DL! Agradeço também aos alunos das turmas que monitorei pelo feedback sobre meu trabalho e por me permitirem aprender na prática a ser professora.

Muito obrigada aos Professores Roberta Pires de Oliveira e Marcos Lopes por terem aceitado participar da minha banca de qualificação. Espero que esse trabalho atenda ao menos em parte às expectativas de vocês.

Agradeço imensamente aos professores Marcus Lunguinho, Roberta Pires de Oliveira, Ana Muller, Jairo Nunes, Luciana Sanchez Mendes e Ana Paula Quadros Gomes por aceitarem participar da minha banca praticamente durante o carnaval.

Sou muito grata aos professores Marcelo Ferreira, Jairo Nunes, Ana Scher e Alexander Cobbinah por terem me escrito cartas de recomendação durante suas férias.

Muito obrigada ao CNPq (processo 130288/2017-9) por financiar esta pesquisa.

Agradeço aos meus colegas da pós-graduação pelo apoio mútuo. Em uma área tão cheia de altos e baixos, é indispensável termos pares que nos mostram que não estamos sozinhos. Obrigada ao Thiago e Luiz Fernando pela companhia nas aulas e no grupo de estudos e pela constante consultoria sobre assuntos de pós. Obrigada à Juliana pelas conversas sobre a semântica e sobre a vida e pela companhia nas aulas, nos grupos de estudos e nos congressos. Obrigada à Camila por me ajudar a segurar a barra (trocadilho intencional), pela constante consultoria sobre gramática tradicional, pelas revisões, pelos passeios no parque, por me emprestar o Joaquim e por não roncar à noite. Obrigada ao Bruno Guide e à Karina Oliveira pelo desempenho impecável como representantes discentes. Espero que tenhamos muitos convescotes pela frente!

Agradeço também aos meus colegas de graduação, sem os quais eu não teria nem chegado à pós. Muito obrigada por todas as anotações emprestadas, os trabalhos em grupo, os picnics, os 'churrascos', os amigos-ocultos e por compartilharem o desespero pré-provas a cada semestre. Tive uma sorte imensa em fazer parte dessa turma! Agradecimentos especiais ao Bonde Discursivo-Formal pelas tardes de pizza e Mario Kart.

Agradeço ao Tarcísio e à Raíssa pelo apoio, pelas dicas de estudo, pelos milhares de litros de café, por acharem que super vai dar tempo de ir na praia antes do congresso começar, pelo apoio 24 horas por dia. Obrigada, Císio, pelos jogos de tabuleiro e pelos filmes de terror. Obrigada, Ray, por ter me tornado uma pessoa muito mais tolerante e 
muito, muito mais organizada.

Aos amigos de fora da academia, Pamella, Renan, Ewerton, Karine, Sodré, Liz, Chibbas, Saru, Meire, Chris, Dan, e tantos outros, obrigada por me tirarem da frente do computador de vez em quando. A todos os meus amigos que forneceram julgamentos de valor de verdade, muito obrigada por escutarem os contextos absurdamente específicos e por aguentarem minha fúria quando seus julgamentos iam contra minhas hipóteses.

À minha família, mãe, pai, Joice, Juliane, Sophia, Ana Clara, Fernando e Robson, agradeço por terem orgulho de mim mesmo sem entender o que eu faço da vida.

Às famílias Takaki (Dona Elza, Shin e batian Aiko) e Ajimura-Hiroi (Emiko, Sr. Milton, Eliana e batian Kiyomi), agradeço por terem me acolhido tão bem e terem tornado São Paulo minha casa. Tenho muita sorte de ter ganhado não uma, mas duas famílias novas.

Obrigada aos coautores desta dissertação, Sr. Vamps, Anninha, e os agregatos que passaram pela minha casa nesses dois anos. Esse trabalho quase inteiro foi escrito com um gato no colo e isso contribuiu bastante para minha qualidade de vida.

Por último, e mais importante, agradeço ao Ivan. Sem ele, talvez esse trabalho fosse possível, mas o processo teria sido muito mais desgastante, e o resultado final, sem dúvida, seria inferior. Obrigada pelo apoio, pelo café, por debugar meus códigos de ${ }^{A} \mathrm{~T}_{\mathrm{E}} \mathrm{X}$, pelo café, por me ajudar com francês, pelo café, por trazer cerveja quando eu estava estressada. E pelo café. 
The good thing about science is that it's true whether or not you believe in it.

A parte boa da ciência é que ela é verdade mesmo que você não acredite nela. (tradução livre)

Neil deGrasse Tyson 


\section{RESUMO}

MENDES, J. V. Interações Modal-temporais no Português Brasileiro. Dissertação (mestrado). Faculdade de Filosofia, Letras e Ciências Humanas. Universidade de São Paulo, 2019.

Esta pesquisa investiga o comportamento temporal de sentenças com os verbos modais poder, dever e ter que no português brasileiro (PB). Tomamos como ponto de partida as noções de perspectiva e orientação temporal, de Condoravdi (2002), que podem ser definidas, grosso modo, como o momento de avaliação modal de uma sentença e o momento de realização da proposição sob o escopo do modal. Os dois objetivos principais deste trabalho são $(i)$ identificar as fontes da perspectiva e orientação temporal de sentenças modais e $(i i)$ identificar e explorar a natureza de potenciais restrições à interpretação temporal dessas sentenças. Em relação à fixação da perspectiva temporal, os dados do PB corroboram a proposta amplamente aceita na literatura de que modais epistêmicos são interpretados acima de TP e de AspP, ao passo que modais raiz são interpretados abaixo dessas duas projeções funcionais. Devido a essa diferença de altura, modais epistêmicos sempre ancoram sua perspectiva temporal no momento de fala, enquanto modais raiz fixam sua perspectiva a partir do Tempo e aspecto da oração. Quanto à orientação temporal, mostramos que as propriedades de cada classe de modais também podem ser facilmente derivadas dessa diferença sintática. Modais epistêmicos podem ter orientações verdadeiramente passadas, que surgem quando o núcleo temporal sob seu escopo é pretérito. Modais raiz, por outro lado, utilizam apenas operadores aspectuais alojados em seus prejacentes para definir sua orientação temporal, o que explica por que esses modais só podem ter orientações presentes, futuras ou perfeitas. Com respeito às restrições à interpretação temporal de sentenças modais, propomos que elas são muito mais circunscritas do que sugerem trabalhos anteriores (Werner (2006), Klecha (2016), entre outros). Assumimos que tendência de modais raiz terem orientação futura é de natureza extralinguística: as noções normalmente transmitidas por esses modais são naturalmente orientadas ao futuro, mas em contextos adequados, orientações presentes e perfeitas podem ser obtidas. A única restrição realmente atestada é a impossibilidade de modais epistêmicos universais serem orientados ao futuro. Seguindo Giannakidou e Mari (2018), explicamos essa restrição como sendo um efeito de bloqueio causado pela competição com o auxiliar do futuro perifrástico $i r$, que seria a forma especializada de expressão de necessidade epistêmica futura.

Palavras chave: Tempo. Modalidade. Aspecto. Perspectiva temporal. Orientação temporal. 


\begin{abstract}
MENDES, J. V. Modal-temporal Interactions in Brazilian Portuguese. Master's dissertation. Faculdade de Filosofia, Letras e Ciências Humanas. Universidade de São Paulo, 2019.

This research investigates the temporal behavior of modal sentences with the verbs poder, dever and ter que in Brazilian Portuguese (BP). We take as a starting point the notions of temporal perspective and temporal orientation (Condoravdi (2002)), which can be roughly defined as the moment of modal evaluation of a sentence and the moment of realization of the proposition under the scope of the modal. The two main objectives of this work are $(i)$ to identify the sources of temporal perspective and orientation of modal sentences and ( $i i)$ to identify and explore the nature of potential constraints to the temporal interpretation of these sentences. When it comes to the source of temporal perspective, the data from BP corroborates the widely-accepted assumption that epistemic modals are interpreted above TP and AspP, while root modals are interpreted below these two functional projections. Because of this difference in height, epistemic modals always anchor their temporal perspective in the speech time, whereas root modals use tense and aspect to define theirs. As for temporal orientation, we have shown that the properties of each class of modals can also be easily derived from this syntactic difference. Epistemic modals can have truly past orientations, which arise when the tense head under their scope is past. Root modals, on the other hand, use only the aspectual operadors hosted in their prejacents to define their temporal orientation, which explains why these modals can only have present, future or perfect orientations. With respect to constraints to the temporal orientation of modal sentences, we propose that they are far more circunscribed than what previous works have suggested (Werner (2006), Klecha (2016), among others). We assumed that the tendency of root modals to be future-oriented is extralinguistic: the notions normally conveyed by these modals are naturally oriented to the future, but, given an appropriate context, present and perfect orientations can be obtained. The only constraint we actually identified is the impossibility of universal epistemic modals being oriented to the future. Following Giannakidou e Mari (2018), we explained this constraint as a blocking effect caused by competition with the perifrastic future auxiliary ir, which would be the specialized form for the expression of future epistemic necessity.
\end{abstract}

Keywords: Tense. Modality. Aspect. Temporal perspective. Temporal orientation. 


\section{Lista de quadros}

1.1 Combinações de Tempo e aspecto no inglês (Kratzer (1998)) ..... . 25

1.2 Combinações de Tempo e aspecto no PB . . . . . . . . . . . . . . 27

2.1 Interpretação temporal de sentenças com modais epistêmicos . . . . . . . . 41

2.2 Interpretação temporal de sentenças com modais raiz . . . . . . . . . . . . 42

4.1 Fontes da orientação temporal em sentenças modais (a revisar) . . . . . . . 67

4.2 Co-variação entre base modal e orientação temporal (Werner $(2003,2006)$ ). 72

4.3 Fontes da orientação temporal em sentenças modais (revisada) . . . . . . . 78

5.1 Classificação de verbos de alçamento de acordo com sua orientação temporal (Abusch (2004)) . . . . . . . . . . . . . . . . . . 99 


\section{Lista de figuras}

4.1 Bases modais de acordo com Werner $(2003,2006)$. . . . . . . . . . 73

4.2 Modelo de mundos ramificados de Thomason (1984) . . . . . . . . . . . . . 91 


\section{Lista de abreviações}

\begin{tabular}{ll}
\hline Asp & núcleo aspectual \\
AspP & sintagma aspectual \\
BC & background conversacional \\
CIRC & circunstancial \\
DP & sintagma determinante \\
EPIS & epistêmico \\
FUT & futuro \\
IMP & imperfectivo \\
Mod & modal \\
ModP & sintagma modal \\
PART & particípio \\
PB & português brasileiro \\
PFTV & perfectivo \\
PL & plural \\
PRES & presente \\
PRET & pretérito \\
PROSP & prospectivo \\
S & sentença \\
SOT & sequence of tenses (sequência de tempos) \\
sse & se e somente se \\
T & núcleo temporal \\
TP & sintagma temporal \\
VP & sintagma verbal \\
\hline
\end{tabular}




\section{Lista de tipos semânticos, variáveis e outros símbolos}

\begin{tabular}{ll}
$e$ & tipo semântico das entidades \\
$t$ & tipo semântico dos valores de verdade \\
$i$ & tipo semântico dos intervalos de tempo \\
$s$ & tipo semântico dos mundos possíveis \\
$\varepsilon$ & tipo semântico das eventualidades \\
$x$ & variável das entidades \\
$p$ & variável das proposições \\
$i$ & variável dos intervalos de tempo \\
$w$ & variável dos mundos possíveis \\
$e$ & variável das eventualidades \\
$h$ & variável das histórias ou cursos históricos \\
$\llbracket \rrbracket$ & extensão \\
$\llbracket \rrbracket$ & intensão \\
$\square$ & necessidade \\
$\diamond$ & possibilidade \\
$\mathcal{F}$ & base modal \\
$\mathcal{G}$ & fonte de ordenação \\
$\varphi$ & proposição \\
$\varnothing$ & tempo zero / morfema zero \\
$*$ & sentença agramatical \\
$\#$ & sentença inadequada ao contexto \\
$\%$ & forma em desuso \\
\hline &
\end{tabular}




\section{Conteúdo}

$\begin{array}{ll}\text { Introdução } & 1\end{array}$

1 Ferramentas teóricas $\quad 5$

1.1 Introdução à semântica intensional . . . . . . . . . . . . . . . . . . . . 5

1.2 Semântica modal . . . . . . . . . . . . . . . . . . . . . . . 10

1.2.1 O Quadro teórico kratzeriano . . . . . . . . . . . . . . . 11

1.2.2 Modalidade verbal no português brasileiro . . . . . . . . . . . 15

1.3 Semântica Temporal . . . . . . . . . . . . . . . . . . . . 20

1.3.1 Tempo e aspecto no português brasileiro . . . . . . . . . . . 25

2 Descrição dos dados $\quad 28$

2.1 Modais epistêmicos . . . . . . . . . . . . . . . . . . . . . . . . . 29

2.1.1 Perspectiva temporal . . . . . . . . . . . . . . . . . . . 29

2.1.2 Orientação temporal . . . . . . . . . . . . . . . . . . 32

2.2 Modais raiz . . . . . . . . . . . . . . . . . . . 35

2.2.1 Perspectiva temporal . . . . . . . . . . . . . . . 35

2.2 .2 Orientação temporal . . . . . . . . . . . . . . . . . . 37

2.3 Conclusão do capítulo . . . . . . . . . . . . . . . . . . . . . . 39

$3 \quad$ Perspectiva temporal $\quad 43$

3.1 Revisão de dados . . . . . . . . . . . . . . . . . . . . . . . . 43

3.1.1 Contraexemplos à perspectiva presente de modais epistêmicos . . . 46

3.2 Estudos anteriores . . . . . . . . . . . . . . . . . . . . . 48

3.2.1 Modais abaixo do TP . . . . . . . . . . . . . . . . . 48

3.2.2 Modais epistêmicos e raiz em alturas diferentes . . . . . . . . . . . 51

3.2 .3 Resumo da seção . . . . . . . . . . . . . . . . . . 56

3.3 As evidências do português brasileiro . . . . . . . . . . . . . 58

3.3.1 Modais epistêmicos podem ter perspectiva passada? . . . . . . . . . 59

3.3.2 Tempo sob o escopo de modais epistêmicos . . . . . . . . . . . . . . 60

3.4 Discrepância morfossemântica . . . . . . . . . . . . . . . . . 62

3.5 Conclusão e questões em aberto . . . . . . . . . . . . . . . . 63 
4 Orientação Temporal $\quad 65$

4.1 Revisão de dados . . . . . . . . . . . . . . . . . . . . . . . 65

4.2 A origem da orientação futura . . . . . . . . . . . . . . . . . 68

4.2 .1 Estudos anteriores . . . . . . . . . . . . . . . . 68

4.2.2 Orientações futuras no português brasileiro . . . . . . . . . . . . . . 74

4.3 Análise composicional . . . . . . . . . . . . . . . . . . 78

4.3 .1 Modais raiz . . . . . . . . . . . . . . . . . . 79

4.3 .2 Modais epistêmicos . . . . . . . . . . . . . . . . 82

4.3.3 Conclusão da seção . . . . . . . . . . . . . . . . . . . . . . . . . . . 84

4.4 Restrições à orientação temporal de verbos modais . . . . . . . . . . . . . 85

4.4 .1 Restrições à orientação temporal no PB . . . . . . . . . . . . . . . . 87

4.4 .2 Um caminho de análise . . . . . . . . . . . . . . . . . 90

4.5 Conclusão . . . . . . . . . . . . . . . . . . . . . . . . . . 95

5 Considerações finais $\quad 97$

5.1 Questões para pesquisas futuras . . . . . . . . . . . . . . . 98 


\section{Introdução}

De acordo com Hockett e Altmann (1968), uma das características definidoras da linguagem humana é sua capacidade de expressar situações que ultrapassam o aqui e o agora. Esse chamado deslocamento, pode ocorrer no domínio da temporalidade, quando nos referimos a situações passadas ou futuras, e no domínio da modalidade, quando falamos de necessidades e possibilidades.

Entre as expressões capazes de desencadear deslocamento modal, verbos modais como poder, dever e ter que são notáveis por sua capacidade de adquirirem leituras diferentes a depender do contexto em que são utilizados. A sentença abaixo, por exemplo, poderia ser dita pela professora do João que nota que seu desempenho nas aulas é excelente. Nesse caso, a necessidade à qual o verbo dever se refere é baseada nas evidências disponíveis à professora. A mesma sentença também poderia ser dita pela professora ao notar que a única maneira de João passar na sua matéria é tirando dez. Nesse segundo contexto, a necessidade à qual o modal dever se refere remete ao objetivo de João passar na matéria.

(2) O João deve tirar dez na prova.

A variedade de significados que podem ser atribuídos aos verbos modais é bastante pervasiva entre as línguas indo-europeias, o que indica que uma análise baseada em ambiguidade lexical seria indesejável. Esse puzzle motivou o trabalho seminal de Angelika Kratzer $(1981,1991,2012)$, no qual a autora propõe que modais seriam quantificadores sobre mundos possíveis cujas entradas lexicais codificariam apenas sua força modal. O restante da contribuição semântica dos modais seria calculado a partir de duas funções providas pelo contexto. Isso permitiu que Kratzer propusesse uma única entrada lexical para cada verbo modal.

Manter o carácter unificador do sistema Kratzeriano têm sido um desafio para os estudiosos que se debruçam sobre a interação entre expressões modais e expressões temporais. Entre as sutilezas dessa interação está a aparente correlação entre sabor modal e interpretação temporal. Verbos modais epistêmicos, por exemplo, parecem sempre se referir às evidências disponíveis no momento de fala, enquanto outros modais podem se referir a possibilidades ou necessidades presentes, passadas ou futuras.

A grande maioria dos estudos sobre a interação entre verbos modais e tempo foi conduzida utilizando o inglês como material empírico. Modais no inglês são morfologicamente 
empobrecidos, o que pode ter criado certos vieses entre estudiosos. Os modais nas línguas românicas, por outro lado, são flexionados para tempo, aspecto e modo, o que os torna um material empírico bastante promissor para estudos sobre modalidade. Ainda assim, há uma escassez de estudos sobre a interação entre modalidade e tempo no português brasileiro (PB). Esta é a principal motivação para o presente trabalho: preencher essa lacuna empírica.

\section{Perspectiva e orientação temporal}

Esta dissertação se pauta pela observação de que a interação entre modalidade e tempo pode dar origem a dois deslocamentos temporais distintos. O primeiro deslocamento diz respeito ao tempo de avaliação modal de uma sentença - o que era possível ou necessário no passado pode não ser mais possível ou necessário no presente ou no futuro. O segundo deslocamento está relacionado ao tempo da proposição sob o escopo do modal. Seguindo Condoravdi (2002), chamaremos esses dois parâmetros de perspectiva e orientação temporal:

Perspectiva temporal A relação temporal estabelecida entre o momento de fala e o momento de avaliação modal.

Orientação temporal A relação entre o tempo de avaliação da proposição sob o escopo de um modal e a perspectiva temporal desse modal.

Essas noções talvez tornem-se mais claras através dos exemplos abaixo, parafraseados de forma a explicitar suas perspectivas e orientações temporais:

(3) a. Em 1920, mulheres não podiam votar.

b. De acordo com as leis no passado, não era possível que as mulheres votassem no passado.

(4) a. O João deve tirar dez na prova.

b. De acordo com as evidências disponíveis agora, o João deve tirar dez na prova no futuro.

O exemplo (3) se refere à impossibilidade de mulheres votarem no passado. O tempo de referência da proposição mulheres votarem é simultâneo à perspectiva temporal do 
modal. Diremos que sentenças como essa têm perspectiva passada e orientação presente. Já o exemplo (4) se refere às evidências disponíveis a um falante no momento da fala. Trata-se de um modal com perspectiva presente. A proposição que o modal toma como complemento tem um tempo de referência futuro em relação à perspectiva temporal do modal. Nesse caso, diremos que o modal tem orientação temporal futura.

\section{Objetivos}

\section{Objetivo geral}

Tomando como ponto de partida as noções de perspectiva e orientação temporal, este trabalho tem como objetivo geral traçar um panorama do comportamento temporal de sentenças com os verbos modais poder, dever e ter que.

\section{Objetivos específicos}

\section{Objetivo I}

O primeiro objetivo desta dissertação é fornecer uma análise semântica composicional para interações modal-temporais no PB. Para tanto, buscaremos identificar os elementos morfossintáticos responsáveis pela obtenção de cada combinação de perspectiva e orientação temporal na língua, indagando sobre a contribuição de cada um desses elementos para as condições de verdade de uma sentença.

\section{Objetivo II}

O segundo pilar deste trabalho será uma investigação sobre a relação entre sabor modal e interpretação temporal. Modais epistêmicos de fato têm perspectiva sempre presente, como é frequentemente assumido na literatura? Há alguma combinação de sabor modal e orientação temporal que não seja atestada no PB? Caso haja, como explicar essa correlação?

Esses objetivos podem ser resumidos na forma das duas perguntas abaixo, que são respondidos ao longo desta dissertação:

1. Quais morfemas entram para a computação da perspectiva e da orientação temporal em sentenças com os verbos modais poder, dever e ter que no PB?

2. Existem restrições à perspectiva ou à orientação temporal de modais epistêmicos ou raiz? Se sim, qual é a natureza dessas restrições? 


\section{Organização da dissertação}

Esta dissertação está organizada da seguinte forma: No capítulo 1, apresentaremos as ferramentas teóricas que utilizaremos ao longo da dissertação: um sistema semântico intensional (seção 1.1), o quadro teórico kratzeriano para verbos modais (seção 1.2) e uma teoria referencial do tempo (seção 1.3). No capítulo 2 faremos uma descrição inicial dos dados do PB, isenta de análises, começando com modais epistêmicos (seção 2.1) e passando então aos modais raiz (seção 2.2).

O capítulo 3 é dedicado à perspectiva temporal de sentenças modais. Na seção 3.1, revisamos os dados relevantes do PB e de algumas outras línguas exploradas em estudos anteriores e propomos que modais epistêmicos de fato sempre têm perspectiva presente. Essa generalização é desafiada por alguns contraexemplos que discutimos na subseção 3.1.1. Na seção 3.2, fazemos uma revisão de parte da literatura sobre perspectiva temporal. Na seção 3.3, apresentamos a contribuição dos dados do PB para a discussão. Nossos resultados sugerem uma discrepância morfossemântica nas sentenças com modais epistêmicos - tempo e aspecto realizados nos modais são interpretados sob seu escopo. Algumas abordagens sintáticas para o fenômeno são discutidas na seção 3.4. A seção 3.5 conclui e resume o capítulo, apresentando questões ainda em aberto.

O capítulo 4 se concentra na orientação temporal de sentenças modais. A exemplo do que fizemos com o capítulo anterior, iniciamos esse capítulo com uma revisão dos dados relevantes (seção 4.1). A discussão que segue é dividida entre a origem da orientação temporal (seção 4.2) e restrições a ela (seção 4.4). Ao final da seção sobre restrições à orientação temporal, apontamos um caminho de análise que nos parece promissor (subseção 4.4.2). Esse capítulo conta também com uma análise formal composicional da interação entre modalidade e tempo no PB (seção 4.3).

O capítulo 5 traz um resumo dos resultados obtidos e das questões em aberto. Nesse capítulo, também fazemos alguns apontamentos para pesquisas futuras. 


\section{Capítulo 1}

\section{Ferramentas teóricas}

Este capítulo tem como objetivo apresentar as ferramentas teóricas que serão utilizadas ao longo desta dissertação. Ele está organizado da seguinte forma: na seção 1.1, apresentamos um sistema semântico intensional, capaz de relativizar a extensão de expressões linguísticas a parâmetros como tempo e mundos possíveis; na seção 1.2, apresentamos o quadro teórico Kratzeriano, que propõe uma semântica duplamente-relativa para expressões modais; finalmente, na seção 1.3, apresentamos uma teoria referencial do tempo, segundo a qual, núcleos temporais se comportariam como proformas. As seções 1.2 e 1.3 são seguidas pela aplicação das teorias apresentadas à descrição do sistema modal e dos tempos verbais do $\mathrm{PB}$.

\subsection{Introdução à semântica intensional}

Dedicaremos esta seção a uma apresentação sucinta de um sistema semântico intensional. Partiremos de uma semântica extensional, como aquela apresentada em Kratzer e Heim (1998)ํ․ Além de Kratzer e Heim (1998), esta seção é baseada nas notas de aula de von Fintel e Heim (2002) e no curso e notas de aula de Ferreira (2017a).

Em um quadro teórico semântico extensional, a denotação de uma expressão linguística é sua extensão - ou seja, o objeto ou fato no mundo para o qual essa expressão aponta.

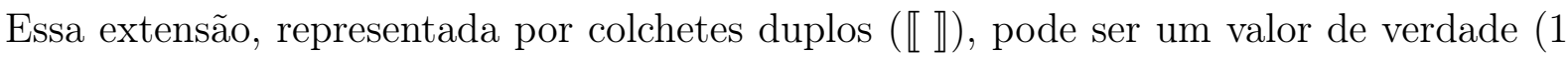
ou 0), como no caso das sentenças; uma entidade, como no caso de nomes próprios; ou uma função, como é o caso dos verbos, por exemplo:

(5) a. $\llbracket$ João $\rrbracket=$ joão

b. $\llbracket$ trabalha $=\lambda x . x$ trabalha

c. 【João trabalha $=1$ sse joão trabalha

\footnotetext{
${ }^{1}$ Veja também Winter (2016).
} 
Cada uma dessas extensões está associada a um tipo e a um domínio semântico. Os tipos semânticos previstos por um sistema extensional podem ser definidos recursivamente através da regra em (6), enquanto os domínios semânticos estão elencados em (7).

(6) Definição recursiva de tipos semânticos:
a. $\quad e$ e $t$ são tipos semânticos;
b. Se $\sigma$ e $\tau$ são tipos semânticos, então $\langle\sigma, \tau\rangle$ é um tipo semântico;
c. Nada mais é um tipo semântico.

(7) Domínios semânticos:
a. $\mathrm{D}_{e}$ : conjunto dos indivíduos;
b. $\mathrm{D}_{t}$ : conjunto dos valores de verdade $(0,1)$;
c. $\mathrm{D}_{\langle\sigma, \tau\rangle}$ : conjunto das funções de $\mathrm{D}_{\sigma}$ em $\mathrm{D}_{\tau}$.

A denotação de uma expressão composta é calculada a partir da denotação de seus constituintes imediatos e de algumas regras composicionais, como a Aplicação Funcional:

\section{(8) Aplicação funcional ${ }^{2}$}

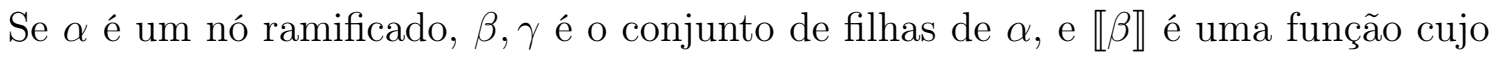
domínio contém $\llbracket \gamma \rrbracket$, então $\llbracket \alpha \rrbracket=\llbracket \beta \rrbracket(\llbracket \gamma \rrbracket)$.

Para efeito de ilustração, considere o exemplo (9).

(9) João estuda Matemática.

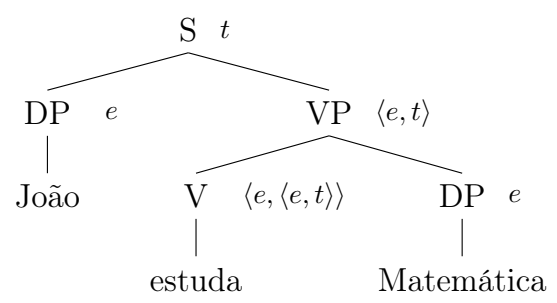

1. $\llbracket \mathrm{VP} \rrbracket=\llbracket \mathrm{V} \rrbracket(\llbracket \mathrm{DP} \rrbracket)$

2. $\llbracket \mathrm{VP} \rrbracket=\lambda x \cdot \lambda y \cdot y$ estuda $x$ (matemática)

3. $\llbracket \mathrm{VP} \rrbracket=\lambda y . y$ estuda matemática

4. $\llbracket \mathrm{S} \rrbracket=\llbracket \mathrm{VP} \rrbracket(\llbracket \mathrm{DP} \rrbracket)$

5. $\llbracket \mathrm{S} \rrbracket=\lambda y . y$ estuda matemática (joão)

6. $\llbracket \mathrm{S} \rrbracket=1$ sse joão estuda matemática

Para o cálculo das condições de verdade de (9), o léxico nos fornece as seguintes denotações:

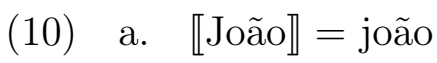

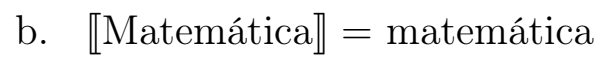

c. $\llbracket$ estudar $\rrbracket=\lambda x_{e} \cdot \lambda y_{e} \cdot y$ estuda $x$

\footnotetext{
${ }^{2}$ Kratzer e Heim (1998, p. 44).
} 
O verbo estudar é modelado como uma função que, quando saturada por um elemento de tipo $e$, retorna outra função. O primeiro constituinte do tipo e é provido pelo argumento interno do verbo, o DP objeto, com o qual o verbo se combina através da Aplicação Funcional. Esta operação resulta em um nó (o VP) cuja extensão é do tipo $\langle e, t\rangle$. Este nó, por sua vez, se combina com o DP sujeito, também do tipo e, saturando sua função e gerando as condições de verdade adequadas para a sentença.

Embora esse sistema semântico seja capaz de lidar com casos mais simples, como (9), exemplos como (11) trazem à tona a limitação de uma semântica puramente extensional.

O Pedro acredita que o João estuda Matemática.

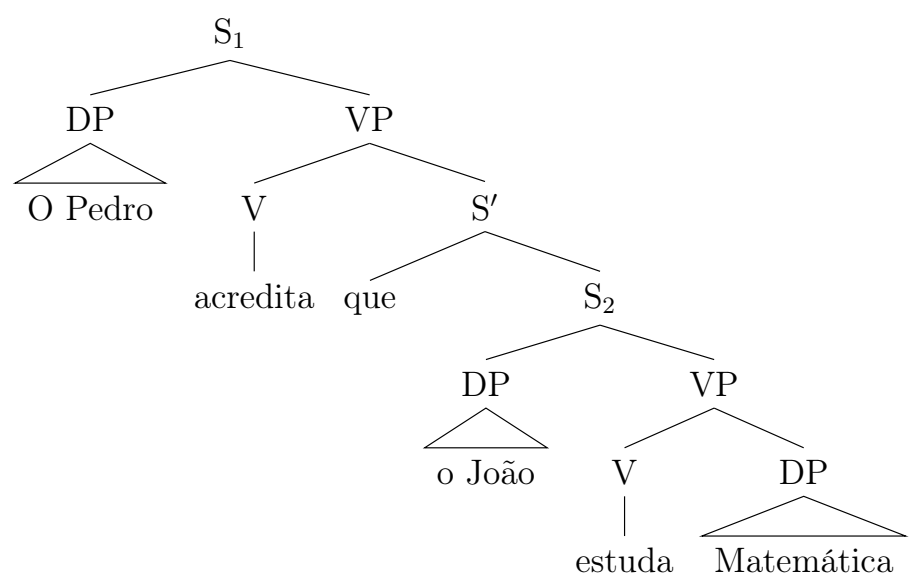

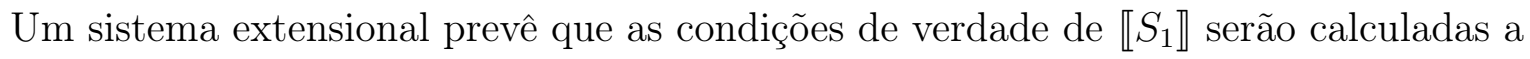
partir das extensões de seus constituintes ${ }^{3}$. Como vimos, a extensão de uma oração é um valor de verdade, logo, $\llbracket S_{2} \rrbracket=1$ sse João estuda Matemática no mundo real. No entanto, tornar as condições de verdade de $\mathrm{S}_{1}$ dependentes da denotação de $\mathrm{S}_{2}$ é contraintuitivo, afinal, é possível que o Pedro acredite que o João estuda Matemática sem que isso seja verdade. Exemplos como esse destacam a necessidade de se relativizar a extensão de componentes sintáticos a alguns parâmetros - no caso em questão, devemos relativizar a extensão de $\mathrm{S}_{2}$ às crenças de Pedro. No jargão técnico, diremos que a extensão de $\mathrm{S}_{2}$ deve ser relativizada aos mundos possiveis que estão de acordo com as crenças de Pedro no mundo real.

Mundos possíveis podem ser definidos como as diferentes e infinitas configurações logicamente coerentes que o mundo poderia assumir ${ }^{4}$. Por exemplo, essa dissertação de mestrado está sendo escrita em um computador. No entanto, ela poderia estar sendo escrita por outro meio. Logo, existem mundos possíveis em que essa dissertação está sendo escrita em uma máquina de escrever, e mundos possíveis em que ela está sendo escrita à mão. Não existem, no entanto, mundos possíveis em que essa dissertação esteja

\footnotetext{
${ }^{3}$ Assumimos que o complementizador que é semanticamente vácuo.

${ }^{4}$ Utilizaremos a letra $w$ e as variações $w^{\prime}, w^{\prime \prime}, w^{\prime \prime \prime}$ para representar mundos possíveis.
} 
sendo escrita à mão e, ao mesmo tempo, ela não esteja sendo escrita à mão, pois esse arranjo de fatos é logicamente incoerente.

Para relativizarmos a extensão de constituintes a mundos possíveis, lançaremos mão de uma noção mais complexa de significado: as intensões. A intensão de um componente $\alpha$ é uma função que toma como argumento um mundo possível $w$ e retornam a extensão de $\alpha$ em $w$ :

$$
\llbracket \alpha \rrbracket_{c}=\lambda w \cdot \llbracket \alpha \rrbracket^{w}
$$

Com essa adição, a ontologia que apresentamos previamente fica da seguinte forma:

\section{(13) Definição recursiva de tipos semânticos:}
a. $\quad$ e e $t$ são tipos semânticos;
b. se $\sigma$ e $\tau$ são tipos semânticos, então $\langle\sigma, \tau\rangle$ é um tipo semântico;
c. se $\sigma$ é um tipo semântico, então $\langle s, \sigma\rangle$ é um tipo semântico;
d. Nada mais é um tipo semântico.

\section{(14) Domínios semânticos:}

Seja $\mathrm{W}$ o conjunto de todos os mundos possíveis.
a. $\mathrm{D}_{e}$ : conjunto dos indivíduos de todos os mundos em $\mathrm{W}$;
b. $\mathrm{D}_{t}$ : conjunto dos valores de verdade $(0,1)$;
c. $\mathrm{D}_{\langle\sigma, \tau\rangle}$ : conjunto das funções de $\mathrm{D}_{\sigma}$ em $\mathrm{D}_{\tau}$;
d. $\mathrm{D}_{\langle s, \sigma\rangle}$ : conjunto das funções de $\mathrm{W}$ em $\mathrm{D}_{\sigma}$.

Operadores intensionais, como verbos de atitude proposicional e verbos modais, tomam como argumento não a extensão de seus complementos, mas sua intensão. Essa intensão é então aplicada aos mundos em que a avaliação dessa oração deve ocorrer. Voltando ao exemplo (11), queremos que a avaliação de $S_{2}$ ocorra apenas nos mundos que estão de acordo com as crenças de Pedro no mundo real. Chamaremos esses mundos de alternativas doxásticas de Pedro no mundo real, ou Dox(Pedro)(w). Assumiremos que o verbo acreditar atua como um quantificador universal sobre esse conjunto de mundos possíveis, tendo a entrada lexical em (15):

$$
\llbracket \text { acredita } \rrbracket^{w}=\lambda p_{\langle s, t\rangle} \cdot \lambda x_{e} \cdot \forall w^{\prime} \in \operatorname{Dox}(x)(w): p\left(w^{\prime}\right)=1
$$

Note que a entrada lexical acima toma um constituinte do tipo $\langle s, t\rangle$ como argumento. Isso gera um problema, pois a oração encaixada sob o verbo acreditar é de tipo $t$. É preciso assumirmos uma regra que permita que os operadores intensionais tomem a intensão de 
seus prejacentes, isto é, de seus complementos, como argumento. A Aplicação Funcional Intensional, introduzida por Kratzer e Heim (1998), ficará a cargo dessa tarefa:

\section{(16) Aplicação Funcional Intensional ${ }^{5}$}

Se $\alpha$ é um nó ramificado e $\{\beta, \gamma\}$ são seus constituintes imediatos, então, para cada mundo possível $w$, se $\llbracket \beta \rrbracket^{w}$ é uma função cujo domínio contem $\lambda w^{\prime} \cdot \llbracket \gamma \rrbracket^{w^{\prime}}$, então $\llbracket \alpha \rrbracket^{w}=\llbracket \beta \rrbracket^{w}\left(\lambda w^{\prime} \cdot \llbracket \gamma \rrbracket^{w^{\prime}}\right)$.

Com essas modificações ao sistema semântico extensional, podemos calcular adequadamente as condições de verdade de (11):

1. $\llbracket \mathrm{VP} \rrbracket^{w}=\llbracket$ acredita $\rrbracket^{w}\left(\lambda w^{\prime} \cdot \llbracket S_{2} \rrbracket^{w^{\prime}}\right)$

2. $\llbracket \mathrm{VP} \rrbracket^{w}=\llbracket$ acredita $\rrbracket^{w}\left(\lambda w^{\prime}\right.$. o João estuda Matemática em $\left.w^{\prime}\right)$

3. $\llbracket \mathrm{VP} \rrbracket^{w}=\left[\lambda p_{\langle s, t\rangle} \cdot \lambda x_{e} . \forall w^{\prime} \in \operatorname{Dox}(x)(w): p\left(w^{\prime}\right)=1\right]$

$\left(\lambda w^{\prime}\right.$. o João estuda Matemática em $\left.w^{\prime}\right)$

4. $\llbracket \mathrm{VP} \rrbracket^{w}=\lambda x_{e} \cdot \forall w^{\prime} \in \operatorname{Dox}(x)(w):$ o João estuda Matemática em $w^{\prime}$

5. $\llbracket S_{1} \rrbracket^{w}=\llbracket \mathrm{VP} \rrbracket^{w}\left(\llbracket \mathrm{O}\right.$ Pedro $\left.\rrbracket^{w}\right)$

6. $\llbracket S_{1} \rrbracket^{w}=1$ sse $\forall w^{\prime} \in \operatorname{Dox}($ Pedro $)(w)$ : o João estuda Matemática em $w^{\prime}$

Esta seção apresentou um sistema semântico intensional capaz de calcular satisfatoriamente as condições de verdade de sentenças com operadores não-verifuncionais. Tais operadores apresentam a particularidade de fazerem com que as condições de verdade das sentenças em que estão inseridos não possam ser calculadas a partir da extensão de seus componentes. Dentro do sistema interpretativo que apresentamos, constituintes sob o escopo desses operadores contribuem para o significado de sentenças através de suas intensões, uma manobra possibilitada pela Aplicação Funcional Intensional. A implementação desse sistema semântico foi ilustrada por uma sentença contendo o verbo de atitude proposicional acreditar, que relativiza a extensão de seu prejacente às alternativas doxásticas de um sujeito no mundo real. Nas próximas seções, exploraremos a aplicação desse sistema semântico no tratamento de verbos modais e de marcadores aspectuais e temporais ${ }^{6}$.

\footnotetext{
${ }^{5}$ Kratzer e Heim (1998, p. 308), tradução nossa.

${ }^{6} \mathrm{E}$ bastante comum entre semanticistas a adoção de um quadro teórico extensional, no qual variáveis de mundo são representadas na sintaxe (Percus (2000), Hacquard (2006), Ferreira (2018), entre muitos outros). Dentro de um sistema extensionalizado, uma sentença é de tipo $\langle s, t\rangle$, o que dispensa o uso da Aplicação Funcional Intensional. Ao longo dessa dissertação, sempre que fizermos menção a um trabalho baseado num quadro teórico extensional, seremos fiéis ao trabalho original e também utilizaremos esse quadro teórico.
} 


\subsection{Semântica modal}

Nesta seção, nos aprofundaremos na discussão sobre as propriedades semânticas de operadores modais. Um bom ponto de partida para essa discussão é a definição que Portner (2009) propõe para modalidade: 'a modalidade é o fenômeno linguístico pelo qual a gramática nos permite dizer coisas sobre, ou com base em, situações que não precisam ser reais' ${ }^{7}$. Em outras palavras, a modalidade é a ferramenta que a linguagem humana nos dá para fazermos deslocamento modal - ou seja, para nos referirmos a situações que não são necessariamente verdadeiras no mundo real.

Além dos verbos de atitude proposicional, as línguas naturais dispõem de um repertório bastante rico de expressões capazes de desencadear deslocamento modal: sufixos, como o -vel em amável e solúvel; advérbios, como possivelmente e necessariamente; sintagmas adjectivais, como ser capaz de e verbos, como poder, dever e ter que. ${ }^{8}$ Essa seção dará ênfase a essa última categoria de modais. No entanto, ao menos que indiquemos o contrário, a análise apresentada aqui pode ser aplicada às expressões modais de forma geral.

A base para uma semântica de verbos modais ${ }^{9}$ será exatamente a mesma que aquela adotada para verbos de atitude proposicional: trataremos verbos modais como quantificadores restritos sobre mundos possíveis.

Dada sua natureza quantificacional, um dos parâmetros que definem a interpretação de um auxiliar modal é sua força modal. Verbos modais normalmente se apresentam como duais de possibilidade e necessidade: por exemplo, os modais ter que, do PB, e have to, do inglês, exprimem a noção de necessidade e podem ser considerados os duais de poder e may. Essa intuição é ilustrada pelos exemplos (17a) e (18a), para os quais paráfrases informais são dadas em (17b) e (18b).

(17) a. O João pode ir à festa.

b. É possível para o João ir à festa.

(18) a. O João têm que chegar na empresa às dez da manhã.

b. É necessáro para o João chegar na empresa às dez da manhã.

Um caso menos óbvio são verbos como dever, do PB, e ought to, do inglês, que parecem ter uma força intermediária entre possibilidade e necessidade. A sentença (19) poderia

\footnotetext{
${ }^{7}$ Portner (2009, pp. 1). Tradução nossa.

${ }^{8}$ Lista adaptada de Kratzer (1981).

${ }^{9}$ Por conveniência, utilizaremos o termo verbos modais para nos referirmos aos itens lexicais poder, dever e ter que. No entanto, temos ciência de que essa nomenclatura é imprecisa, visto que o estatuto dessas palavras no PB ainda se encontra em aberto. De acordo com Lunguinho (c.p.), poder parece se comportar como um auxiliar modal, ao passo que dever e ter que se comportam como verbos plenos.
} 
ser parafraseada como 'é melhor que as crianças durmam oito horas por dia do que elas não durmam'.

(19) Crianças devem dormir pelo menos oito horas por dia.

Voltaremos a esse ponto no final desta seção, quando discutiremos algumas propostas para modelar verbos modais com esse comportamento. Por ora, nos concentraremos nos verbos que expressam inequivocamente possibilidade ou necessidade.

O segundo ingrediente da semântica dos verbos modais é a fonte da restrição de seu domínio de quantificação. Nesse sentido, os verbos modais apresentam um comportamento distinto dos verbos de atitude proposicional. Na seção anterior, adotamos uma análise segundo a qual os verbos de atitude proposicional tinham essa restrição fixada em sua entrada lexical. Se adotarmos uma análise idêntica para verbos modais, teremos problemas para lidar com exemplos como (20):

(20) O Pedro pode chegar depois das onze...

a. o trânsito está meio pesado hoje.

b. a reunião dele só começa às 11 h30.

c. os horários do trabalho dele são flexíveis.

Uma alternativa para lidar com a variedade de interpretações dos verbos modais seria admitirmos um caso de homonímia. Em outras palavras, poderíamos assumir que o léxico dos falantes do PB têm várias entradas lexicais cuja expressão fonológica é poder, dever ou ter que. Isto significaria equiparar a diversidade interpretativa dos verbos modais à de palavras como manga. No entanto, a homonímia normalmente emerge de coincidências históricas. Duas palavras homônimas não estão relacionadas semanticamente ou etimologicamente, logo, é improvável que encontremos os mesmos exemplos de homônimos em línguas de famílias distintas. Por outro lado, a variedade de leituras dos verbos modais é bastante pervasiva entre as línguas do mundo, o que torna indesejável uma análise baseada em ambiguidade lexical.

\subsubsection{O Quadro teórico kratzeriano}

Para resolver esse puzzle, Kratzer (1981), propôs que verbos modais como must e can teriam uma entrada lexical única, que especificaria apenas sua força modal - necessidade no primeiro caso, possibilidade no segundo. O conjunto de mundos possíveis sobre os quais esses verbos quantificam seria então restringido através de backgrounds conversacionais (BCs), isto é, funções que mapeiam mundos possíveis em conjuntos de proposições (Kratzer (2012, pp. 32)). A vantagem dessa análise é que ela permite que um dos parâmetros que compõem o significado de um modal seja definido pelo contexto em que 
certa sentença foi proferida, o que fornece uma explicação natural para a variedade de significados ilustrada em (20). Será esse o quadro teórico que adotaremos para lidar com verbos modais ao longo desta dissertação.

BCs podem ser subdivididos em duas categorias: aqueles que representam fatos sobre o mundo, ou seja, são sempre consistentes, e que aqueles que representam ideais, podendo ser consistentes ou não. Kratzer (2012, pp. 32, 33, 37) lista alguns BCs particularmente importantes para a semântica dos modais (tradução nossa):

\section{(21) Backgrounds conversacionais fatuais}

a. Backgrounds conversacionais realistas

Uma função $f$ tal que para qualquer mundo $w, w \in \cap f(w)$. Ou seja, $f$ designa a todos os mundos possíveis o conjunto das proposições que são verdadeiras neles.

b. Backgrounds conversacionais totalmente realistas

Uma função $f$ tal que para qualquer mundo $w \in W, \cap f(w)=\{w\}$. Ou seja, $f$ designa a todos os mundos possíveis um conjunto de proposições que o caracteriza unicamente.

\section{(22) Backgrounds conversacionais não-fatuais}

a. Backgrounds conversacionais informacionais

Uma função $f$ tal que para qualquer $w$ no domínio de $f, f(w)$ representa o conteúdo proposicional de alguma fonte de informação em $w$.

b. Backgrounds conversacionais estereotípicos

Uma função $f$ tal que para qualquer mundo $w, f(w)$ representa o que é normal em $w$ de acordo com algum padrão de normalidade em $w$.

c. Backgrounds conversacionais deônticos

Uma função $f$ tal que para qualquer mundo $w, f(w)$ representa o conteúdo de um corpo de leis e regulamentos em $w$.

Kratzer (2012, pp. 37) menciona ainda BCs buléticos, que são relacionados a desejos, teleológicos, relacionados a objetivos, e o $\mathrm{BC}$ vazio.

Em resumo, o sistema Kratzeriano tal qual ele foi apresentado até este ponto atribui a contribuição semântica de expressões modais a dois parâmetros - a força modal, que é lexicalmente codificada, e a um BC, que define o conjunto de mundos sobre o qual o modal quantifica. Esses elementos são mostrados nas entradas lexicais abaixo (adaptadas de Kratzer (2012)): 
(23) a. $\quad \llbracket \operatorname{poder}_{f} \rrbracket^{w}=\lambda p . \exists w^{\prime} \in \cap f(w): p\left(w^{\prime}\right)=1$

b. $\llbracket$ ter $\mathrm{que}_{f} \rrbracket^{w}=\lambda p . \forall w^{\prime} \in \cap f(w): p\left(w^{\prime}\right)=1$

Contudo, essa análise bipartite ainda é insuficiente para lidar com toda a gama de significados dos modais. Considere o exemplo abaixo:

\section{a. Contexto}

Entre as noites de quinta e sexta-feira, João deu uma festa bastante animada em sua casa. A festa se estendeu até as 4 horas da manhã, o que fez com que alguns vizinhos dele chamassem a polícia. A pena para perturbação do sossego no Brasil consiste no pagamento de uma multa.

b. O João tem que pagar uma multa.

A sentença (24b) é feliz no contexto (24a), que favorece uma leitura deôntica. No entanto, se assumirmos que o modal ter que combina-se apenas com um BC deôntico no contexto acima, cairemos num dilema: nos mundos que estão de acordo com as leis brasileiras, o João não paga uma multa, visto que nesses mundos ele sequer perturbaria o sossego de seus vizinhos. A intuição que emerge de exemplos como (24b) é de que modais não quantificam necessariamente sobre os mundos que estão de acordo com certos ideais, mas sim sobre mundos que chegam mais perto desses ideais.

\section{Modalidade duplamente-relativa}

Exemplos como (24) destacam a necessidade de não apenas definirmos os mundos possíveis relevantes para a interpretação de uma sentença, mas também, ordená-los. Kratzer (2012) propõe então, que o domínio de quantificação de um modal seria duplamente relativo. Um primeiro $\mathrm{BC}$ forneceria o conjunto de mundos sobre o qual o modal quantifica, enquanto um segundo BC funcionaria como um ideal de acordo com o qual esses mundos são ordenados.

Chamaremos esse primeiro conjunto de base modal $(\mathcal{F})$. Kratzer (1981) prevê a existência de dois tipos de base modal: as bases modais circunstanciais e as bases modais epistêmicas. Bases modais circunstanciais selecionam mundos que replicam certas circunstâncias em $w$, enquanto bases modais epistêmicas selecionam mundos que estão de acordo com o conhecimento de um agente em $w$. A partir dessa distinção, podemos separar expressões modais em dois grupos: modais raiz e modais epistêmicos.

O segundo BC envolvido na interpretação de modais é chamado de fonte de ordenação $(\mathcal{G})^{10}$ do modal. A ordenação de mundos pode ser modelada da seguinte maneira:

\footnotetext{
${ }^{10} \mathrm{BCs}$ realistas, como aqueles listados em (21), servem como bases modais, enquanto BCs potencialmente não-realistas, como os listados em (22) funcionam como fontes de ordenação.
} 


\section{(25) Induzindo uma ordenação $\leq_{\mathcal{G}(w)}$}

Para todos os mundos $u$ e $v \in W: u \leq_{\mathcal{G}(w)} v$ sse $\{p: p \in \mathcal{G}(w)$ e $v \in p\} \subseteq\{p: p \in$ $\mathcal{G}(w)$ e $u \in p\}$

Isso significa que, dada uma dupla de mundos $u$ e $v$, para que $u$ seja considerado no mínimo tão próximo do ideal estabelecido por $\mathcal{G}(w)$ quanto $v$, basta que o conjunto de proposições de $\mathcal{G}(w)$ verdadeiras em $v$ seja um subconjunto do conjunto de proposições de $\mathcal{G}(w)$ que são verdadeiras em $u$.

Voltando ao exemplo (24), agora podemos dizer que a base modal de ter que é circunstancial, sendo constituída pelos mundos que estão de acordo com certos fatos em $w$ por exemplo, o fato de que João deu uma festa e de que a festa terminou muito tarde. O ideal de acordo com o qual os mundos na base modal serão ordenados é o Código Penal Brasileiro. Ou seja, trata-se de uma fonte de ordenação deôntica.

Com base nos parâmetros de base modal e fonte de ordenação, Kratzer (2012) define necessidade e possibilidade da seguinte maneira:

(26) Necessidade:

Uma proposição $p$ é uma necessidade em $w$ com respeito a $\mathcal{F}$ e $\mathcal{G}$ se e somente se $p$ é verdadeira em todos os mundos possíveis de $\cap \mathcal{F}(w)$ que estão mais bem ranqueados de acordo com o ideal determinado por $\mathcal{G}$.

\section{(27) Possibilidade:}

Uma proposição $p$ é uma possibilidade em $w$ com respeito a $\mathcal{F}$ e $\mathcal{G}$ se e somente se sua negação não for uma necessidade em $w$ com respeito a $\mathcal{F}$ e $\mathcal{G}$.

Por conveniência, faremos a chamada Limit Assumption ${ }^{11}$, isto é, assumiremos que sempre existe um conjunto de mundos que estão mais próximos do ideal estabelecido pela fonte de ordenação. Chamaremos esses mundos de $\operatorname{Best}_{\mathcal{G}(w)}(\cap \mathcal{F}(w))$, o que nos permitirá simplificar a entrada lexical dos modais:

$$
\begin{aligned}
& \text { a. } \llbracket \operatorname{poder}_{\mathcal{F}, \mathcal{G}} \rrbracket^{w}=\lambda p . \exists w^{\prime} \in \operatorname{Best}_{\mathcal{G}(w)}(\cap \mathcal{F}(w)): p\left(w^{\prime}\right)=1 \\
& \text { b. } \llbracket \text { ter que }_{\mathcal{F}, \mathcal{G}} \rrbracket^{w}=\lambda p . \forall w^{\prime} \in \operatorname{Best}_{\mathcal{G}(w)}(\cap \mathcal{F}(w)): p\left(w^{\prime}\right)=1
\end{aligned}
$$

Quanto à sintaxe dos verbos modais, assumiremos com Hackl (1998), Wurmbrand (1999), Kratzer (2013), entre outros, que tanto modais epistêmicos quanto raiz são predicados de alçamento. Isso significa que o sujeito de sentenças modais é gerado como sujeito da oração não-finita sob escopo do modal, e alçado a uma posição hierarquicamente superior a ele, podendo ou não ser reconstruído em sua posição original. Essa análise encontra

\footnotetext{
${ }^{11} C f$. Portner (2009) e as referências ali contidas para uma discussão acerca das vantagens e desvantagens de se fazer a Limit Assumption. Note, no entanto, que essa questão é tangencial à atual pesquisa, visto que nossa investigação se concentra apenas na relação entre base modal e interpretação temporal.
} 
apoio empírico na disponibilidade de leituras de dicto ${ }^{12}$ em sentenças tanto com modais raiz, como (29), quanto epistêmicos, como (30 $)^{13}$ :

(29) A lot of people can jump in this pool. muita gente pode pular em essa piscina

'Muita gente pode pular nessa piscina.'

(30) A lot of people may have jumped in this pool. muita gente pode ter pulado em essa piscina

'Muita gente pode ter pulado nessa piscina.'

Em síntese, nessa seção apresentamos o quadro teórico Kratzeriano para expressões que desencadeiam deslocamento modal. De acordo com esse sistema, três parâmetros compõem a contribuição semântica dos modais: a força modal, a base modal e a fonte de ordenação. Dentre esses três parâmetros, apenas a força modal é lexicalmente codificada, enquanto a base modal e a fonte de ordenação são providas pelo contexto de uso. Isso nos permite explicar a variedade de interpretações que podem ser atribuídas a um modal sem que tenhamos de recorrer à ambiguidade lexical. Essa é uma característica bastante desejável da proposta de Kratzer (2012), visto que, translinguisticamente, é bastante comum que diversas leituras sejam atribuídas a um mesmo auxiliar. Na próxima subseção, utilizaremos essa teoria para descrever os modais do PB.

\subsubsection{Modalidade verbal no português brasileiro}

O sistema de verbos modais no PB conta com três itens lexicais: poder, dever e ter que $e^{14}$. Sintaticamente, esses verbos selecionam infinitivos não-flexionados (Lunguinho (2014)):

(31) Os professores podem / devem / têm que corrigir / * corrigirem as provas até semana que vem.

Os modais do PB recebem marcação de pessoa, número, tempo, modo e aspecto, podendo ser conjugados em todos os tempos dos modos indicativo e subjuntivo. O verbo dever é uma exceção a essa regra. Por ser defectivo, esse verbo não dispõe de uma forma de pretérito perfectivo (32), e não pode ocorrer após um auxiliar (33):

\footnotetext{
${ }^{12} \mathrm{~A}$ leitura de dicto é a leitura que emerge quando o sujeito de sentenças com sintagmas quantificadores é interpretado sob o escopo de um operador - nesse caso, o operador modal. Remetemos o leitor a von Fintel e Iatridou (2003) e Iatridou e Sichel (2011) para investigações sobre os fatores que dão origem às leituras de re e de dicto em sentenças modais.

${ }^{13}$ Exemplos de Hackl (1998).

${ }^{14}$ Ter que está sujeito a variação, podendo ser realizado como ter de. Acreditamos, no entanto, que ter de não apresenta nenhuma diferença semântica significativa que justifique uma análise separada para essa forma.
} 
(32) a. Eu pude entregar o trabalho uma semana antes do prazo.

b. Eu tive que entregar o trabalho uma semana antes do prazo.

c. ${ }^{*}$ Eu devi entregar o trabalho uma semana antes do prazo.

(33) a. Os alunos vão poder entregar o trabalho uma semana antes do prazo.

b. Os alunos vão ter que entregar o trabalho uma semana antes do prazo.

c. * Os alunos vão dever entregar o trabalho uma semana antes do prazo.

Duas questões acerca da semântica desses verbos permanecem abertas a debate. A primeira questão diz respeito às bases modais com as quais eles podem se combinar. Alguns verbos modais exibem uma tendência à especialização, combinando-se apenas com bases modais epistêmicas ou circunstanciais. Seria esse o caso de algum modal no $\mathrm{PB}$ ?

O outro ponto ainda em discussão é a força modal de cada um desses verbos. Lembrese que no sistema Kratzeriano que tomamos como base para essa pesquisa, apenas a força modal de um auxiliar é codificada lexicalmente. Isso significa que modais podem quantificar existencialmente ou universalmente sobre mundos possíveis. Que poder age como um quantificador existencial e ter que como um quantificador universal parece bastante claro. Não há um consenso, no entanto, sobre a melhor maneira de modelar verbos como dever, que parecem ter uma força quantificacional intermediária entre possibilidade e necessidade.

Abordaremos primeiro a questão da especialização dos modais do PB. Esse é um ponto controverso entre os estudiosos da modalidade no PB. De acordo com Pires de Oliveira e Scarduelli (2009) e Lunguinho (2014), o modal ter que seria especializado em leituras raiz. Lunguinho (2014) baseia sua conclusão na ausência de ocorrências do ter que epistêmico na produção naturalística de duas crianças adquirindo o PB. A análise de Pires de Oliveira e Scarduelli (2009), por outro lado, apoiou-se em dados de um corpus de PB escrito (Folha de São Paulo) e dois de PB falado (Varsul e Nurc).

Pessotto $(2014,2015)$ adotou uma posição mais branda. Baseando-se em dados experimentais, a autora observou que dever é preferível em contextos evidenciais, ao passo que ter que seria mais utilizado nos demais contextos. Contudo, nenhum dos dois modais seja incapaz de se combinar com qualquer base modal.

Se nossa intuição está correta, dado um cenário adequado, o uso do ter que epistêmico não é apenas possível, mas preferível. Considere, por exemplo, a sentença (34b) no contexto (34a). Em vista das evidências fornecidas, o verbo dever na sentença (34b) não nos parece ser suficientemente forte para descrever a conclusão do legista. ${ }^{15}$

\footnotetext{
${ }^{15} \mathrm{Na}$ seção 2.1.2, mostraremos que ter que em sua leitura epistêmica é de fato inaceitável em sentenças com orientação futura. Talvez isso explique a aparente preferência pelo dever epistêmico.
} 
(34) a. Contexto: Um cientista forense é chamado à cena de um assassinato para examinar um corpo. A temperatura do cadáver no momento do exame é $30^{\circ} \mathrm{C}$. Ciente de que, naquelas condições, o corpo humano perde $1.5^{\circ} \mathrm{C}$ por hora após a morte, e de que a temperatura corporal de uma pessoa viva e saudável é de cerca de $36.5^{\circ} \mathrm{C}$, o cientista afirma:

b. Essa pessoa tem que ter morrido há pelo menos três horas.

Para essa pesquisa, nos baseamos em exemplos como (34b) e assumimos que todos os modais do PB podem se combinar tanto com uma base modal epistêmica quanto circunstancial.

A segunda questão a ser abordada é a força modal do verbo dever. Esse modal apresenta uma particularidade em relação aos outros modais do PB por servir como dual tanto de poder quanto de ter que ${ }^{16}$. Isso é mostrado nos exemplos em (35) e $(36)^{17}$ :

\section{(35) Dever e poder:}

a. Os estagiários não devem trabalhar nos fins de semana, mas podem.

b.\# Os estagiários não podem trabalhar nos fins de semana, mas devem.

c. Os estagiários não apenas podem trabalhar nos fins de semana, como também devem.

d.\# Os estagiários não apenas devem trabalhar nos fins de semana, como também podem.

\section{(36) Dever e ter que:}

a. Os estagiários não têm que trabalhar nos fins de semana, mas devem.

b.\# Os estagiários não devem trabalhar nos fins de semana, mas têm que.

c. Os estagiários não apenas devem trabalhar nos fins de semana, como também têm que trabalhar.

d.\# Os estagiários não apenas têm que trabalhar nos fins de semana, como também devem.

Os testes em (35) mostram que asserções com dever acarretam aquelas com poder, mas o oposto não ocorre. Além disso, é possível reforçar uma sentença com poder através de uma com dever. Testes assim indicam que dever pode agir como dual de poder. Quando executamos os mesmos testes entre dever e ter que, em (36), os resultados indicam que

\footnotetext{
${ }^{16}$ Para que esses testes funcionem, é necessário que os dois modais sejam interpretados contra o mesmo $\mathrm{BC}$, nesse caso, o estatuto de uma certa empresa.

${ }^{17}$ Exemplos baseados em Pessotto (2014), que, por sua vez, baseou-se em von Fintel e Iatridou (2008).
} 
ter que acarreta dever e também pode ser utilizado para reforçá-lo, o que, novamente, indica que dever e ter que podem ser considerados duais.

Como já mencionamos na seção 1.2, modais que resistem à dicotomia possibilidadenecessidade não são exclusividade do PB. De fato, um corpo crescente de evidência translinguística mostra que esse parece ser o padrão entre línguas não-indo-europeias ${ }^{18}$. Ao longo do restante dessa subseção, elencaremos algumas abordagens disponíveis na literatura para o tratamento desses modais e apontaremos aquela que nos parece mais adequada para lidar com o verbo dever. Os próximos parágrafos se apoiam em grande parte na discussão apresentada em Kratzer, Pires de Oliveira e Pessotto (2014).

A primeira proposta a ser discutida parte de von Fintel e Iatridou (2008), que conduziram um estudo translinguístico a fim de mapear a expressão da necessidade fraca nas línguas do mundo. Os autores concluíram que a morfologia normalmente associada à noção de contrafactualidade (que, no PB, é expressa pela marcação de futuro do pretérito ou de pretérito imperfectivo) também tem o efeito de enfraquecer modais que expressam necessidade. Isso é ilustrado por exemplos como $(37)^{19}$ :

a. Deberia limpiar los platos, pero no estoy obligado.

deveria limpar os pratos, mas não estou obrigado

'Eu deveria lavar a louça, mas não sou obrigado.'

b. Teria que limpiar los platos, pero no estoy obligado. teria que limpar os pratos, mas não estou obrigado

'Eu teria que lavar a louça, mas não sou obrigado.'

c. \# Tengo que limpiar los platos, pero no estoy obligado. tenho que limpar os pratos, mas não estou obrigado

'Eu tenho que lavar a louça, mas não sou obrigado.'

O exemplo (37c) mostra que a negação da obrigação expressa por ter que gera uma sentença contraditória. Os exemplos (37a) e (37b), por outro lado, mostram que, com a adição da morfologia de contrafactualidade, essa contradição é cancelada. Von Fintel e Iatridou (2008) enfatizam, no entanto, que a marcação de contrafactualidade não é condição sine qua non para a emergência da leitura de necessidade fraca, visto que algumas línguas lexicalizam essa noção. Esse é o caso, por exemplo, do holandês, que apresenta o modal de necessidade fraca horen e do próprio inglês, que conta com o ought, além, é claro, do dever do PB.

\footnotetext{
${ }^{18}$ Cf., entre outros, Matthewson, Davis e Rullmann (2007), que traz dados do St'át'imcets e Deal (2011), que traz dados do Nez Perce.

${ }^{19}$ Exemplos (19) - (21) em von Fintel e Iatridou (2008). Dados e julgamentos do espanhol atribuídos a Karlos Arregi.
} 
A análise dos autores consiste em propor que os chamados modais de necessidade fraca teriam seu significado composto por duas fontes de ordenação, em vez de apenas uma. Essa segunda fonte de ordenação teria o papel de refinar o ranqueamento feito pela primeira. Vejamos como essa proposta nos permite lidar com modais teleológicos, como aqueles nos exemplos em $(38)^{20}$ :

(38) a. Para ir a Ashfield, você tem que usar a Rota 2.

b. Para ir a Ashfield, você deve usar a Rota 2.

Ao dizer a sentença (38a), o falante sugere que não há outra maneira de chegar a Ashfield que não envolva usar a Rota 2. Já a sentença (38b) implica a existência de outras rotas possíveis para acessar o local. Nesse caso, o modal indica que a Rota 2 é a melhor rota com base em algum parâmetro adicional, como, por exemplo, a paisagem ou a velocidade com a qual se chegará ao destino. A primeira fonte de ordenação seria responsável por ordenar os mundos da base modal de acordo com o objetivo de chegar a Ashfield. A segunda fonte de ordenação ordenaria esses mundos de acordo com esse parâmetro adicional. Dessa forma, a força modal dos verbos ter que e dever seria a mesma: ambos seriam modelados como modais de força universal. A diferença de força na interpretação desses verbos viria do domínio modal reduzido de dever.

Uma das críticas que Kratzer (2014) faz a essa proposta é o fato de que ela não explica uma das características mais importantes de modais como dever - o fato de que esses modais não têm duais. A autora demonstra esse fenômeno através do comportamento de ought em contextos de downward e upward entailment, como as sentenças (39) e $(40)^{21}$.

(39) a. Nobody ought to enter the room.

ninguém deve entrar na sala

b. Nobody may enter the room.

ninguém pode entrar na sala

(40) a. Everybody ought to pay taxes.

todos devem pagar impostos

b. Everybody has to pay taxes.

todos têm que pagar impostos

Em (39a), o QP negativo nobody cria um ambiente de downward entailment que permite que a sentença seja parafraseada com um modal mais fraco, o may. Já (40a) cria

\footnotetext{
${ }^{20}$ Traduzidos dos exemplos (6) e (7) de von Fintel e Iatridou (2008).

${ }^{21}$ Exemplos (4) - (7) em Kratzer, Pires de Oliveira e Pessotto (2014).
} 
um contexto de upward entailment e pode ser parafraseada com um modal mais forte, o have to. Esse comportamento não é exibido por modais com duais.

Deal (2011) utiliza testes de acarretamento como esses para diagnosticar a força quantificacional do sufixo modal o'qa, da língua Nez Perce, que a autora propõe ser um existencial. Se adotássemos essa visão, novamente teríamos dificuldade em explicar por que verbos como dever não têm um dual.

Uma análise bastante promissora para essa questão é de que verbos como dever ${ }^{22}$ operam como modificadores de grau (Kratzer (2012), Klecha (2014), Portner e Rubinstein (2016), entre outros). Essa parece ser a única proposta que explica por que esses modais não têm um único dual. Qualquer que seja a abordagem favorita do leitor, o ponto crucial para nós é que dever não é um modal de necessidade (forte) ${ }^{23}$.

\subsection{Semântica Temporal}

Para essa pesquisa, adotamos uma teoria referencial do tempo, como aquela proposta por Partee (1973) e Kratzer (1998), entre outros. De acordo com esse quadro teórico, um núcleo temporal pode ser entendido como uma espécie de proforma que denota um intervalo de tempo contextualmente saliente. Tal visão se opõe a uma teoria quantificacional do tempo, segundo a qual tempos são vistos como operadores existenciais. ${ }^{24}$

Um primeiro indício de que um tratamento referencial para o tempo seria desejável pode ser encontrado em Partee (1973), que elenca diversos usos em comum de núcleos temporais e pronomes. Um exemplo dessas similaridades são pronomes e tempos dêiticos. A sentença em (41), por exemplo, normalmente acompanhada de um gesto de mão, ilustra um uso dêitico do pronome ele.

(41) Ele não deveria estar aqui. ${ }^{25}$

O uso dêitico de tempos, por sua vez, pode ser ilustrado por sentenças como $(42)^{26}$. Imagine que (42) foi dita por uma pessoa que acabou de sair de casa a caminho do trabalho. De acordo com Partee (1973), o tratamento do morfema de pretérito em (41) como um operador existencial levaria a condições de verdade equivocadas. Se propusermos que a negação tem escopo sobre o operador temporal, as condições de verdade da sentença, parafraseadas em (42a), afirmariam que não existe nenhum momento no passado em que o falante desligou o fogão. Por outro lado, se assumirmos que o operador temporal tem

\footnotetext{
${ }^{22}$ De fato, essa análise já foi sugerida por Pessotto (2014) para o dever.

${ }^{23}$ Por simplicidade, no entanto, manteremos a entrada lexical de dever idêntica à de ter que ao longo desta dissertação.

${ }^{24}$ Para uma crítica a essa teoria e uma defesa de uma teoria quantificacional do tempo, $c f$. von Stechow (2009).

${ }^{25}$ Exemplo (2) em Partee (1973).

${ }^{26}$ Exemplo (3) em Partee (1973).
} 
escopo sobre a negação, chegaríamos às condições de verdade em (42b), que afirmam que existe algum momento do passado em que o falante não desligou o fogão. O primeiro resultado parece ser muito mais forte do que o significado pretendido para essa sentença, enquanto a segunda opção parece fraca demais.

(42) Eu não desliguei o fogão.

a. $\neg \exists t[t<$ agora \& eu desliguei o fogão em $t]$

b. $\exists t[t<$ agora \& eu não desliguei o fogão em $t]$

De fato, o morfema de passado em (42) não parece se referir a um instante específico, mas sim a um intervalo de tempo. Da mesma maneira que o pronome ele em (41) se refere a uma entidade saliente no contexto, o intervalo de tempo denotado pelo pretérito só se torna claro por meio de pistas contextuais. No caso em questão, podemos supor que esse intervalo se estende desde a última vez em que o falante utilizou o fogão até o momento em que ele saiu de casa.

Baseando-se nas ideias de Partee (1973), Kratzer (1998) mostra que as analogias entre pronomes e núcleos temporais oferecem uma explicação elegante para o fenômeno de sequence of tenses (SOT), ilustrado pelos exemplos abaixo:

$$
\begin{aligned}
& \text { John said he would buy a fish that } \underline{\text { was }} \text { still alive. } \\
& \text { joão disse ele iria comprar um peixe que } \underline{\text { estivesse }} \text { ainda vivo } \\
& \text { 'O João disse que ele iria comprar um peixe que ainda estivesse vivo' }
\end{aligned}
$$

(44) Mary predicted that she would know that she was pregnant the minute she maria previu que ela iria saber que ela estava grávida o minuto ela got pregnant.

estivesse grávida

'A Maria previu que ela iria saber que ela estava grávida no minuto em que ela estivesse grávida.'

Note que nos exemplos (43) e (44), os verbos sublinhados não são interpretados como passado, apesar de sua morfologia. Nos dois casos, o pretérito parece apenas espelhar uma ocorrência mais alta do mesmo tempo verbal, sem contribuir para a interpretação da sentença. Kratzer (1998) aponta que o mesmo fenômeno ocorre com pronomes indexicais:

(45) Only I got a question that $\underline{I}$ understood. só eu recebi uma questão que eu entendi

'Só eu recebi uma pergunta que en entendi.' 
A sentença $(45)^{27}$ tem duas leituras possíveis: Na primeira leitura (strict reading) o pronome sublinhado recebe sua interpretação indexical, ou seja, se refere ao falante da sentença. Na segunda leitura (sloppy reading), o pronome é interpretado como uma variável ligada. Nesse último caso, a sentença poderia ser informalmente parafraseada como 'além de mim, nenhum indivíduo tem a propriedade de ser um $x$ tal que $x$ recebeu uma pergunta que $x$ entendeu'. De maneira análoga ao que ocorreu com o passado nos exemplos (43) e (44), o pronome $I$ perde seus traços interpretáveis.

Casos como esses levam Kratzer (1998) a teorizar sobre a existência de pronomeszero $(\varnothing)$, que entrariam na derivação sintática sem traços- $\phi$ e poderiam receber material fonológico de um antecedente em PF. Assumindo a presença de tal pronome, a leitura sloppy de (45) poderia ser representada como (46):

$[\text { Only I }]_{1}$ got a question that $\varnothing_{1}$ understood.

Seguindo a mesma linha de raciocínio, Kratzer (1998) propõe que também deva existir um tempo-zero, o que explicaria a ocorrência de SOT nos exemplos (43) e (44). Esse tempo-zero não teria traços interpretáveis e apenas herdaria a marcação temporal dos operadores sob os quais se encaixa. Sendo assim, o repertório de tempos indicativos do PB seria constituído por um presente, um pretérito e um tempo-zero, aos quais podemos atribuir as seguintes entradas lexicais:

$$
\llbracket \text { presente }_{i} \rrbracket^{g}= \begin{cases}g(i) & \text { se } g(i)=\text { momento de fala } \\ \text { indefinido } & \text { nos demais casos }\end{cases}
$$

(48) $\llbracket$ pretérito $_{i} \rrbracket^{g}= \begin{cases}g(i) & \text { se } g(i)<\text { momento de fala } \\ \text { indefinido } & \text { nos demais casos }\end{cases}$

(49) $\llbracket \varnothing_{i} \rrbracket^{g}=g(i)$

As entradas lexicais acima capturam o componente indexical dos tempos verbais. O presente se refere a um intervalo de tempo provido pelo contexto, o próprio momento de fala, e é indefinido quando o contexto não fornece esse intervalo. Já o passado só é definido se o contexto fornece intervalos anteriores ao momento de fala. No entanto, apenas essa premissa não é o suficiente para explicar as diferenças interpretativas entre os exemplos em (51).

\footnotetext{
${ }^{27}$ Exemplo atribuído a Irene Heim por Kratzer (1998).
} 
(50) a. (Ontem à tarde,) o João arrumou a casa.

b. (Quando a Maria chegou,) o João estava arrumando a casa.

c. (Quando a Maria chegou,) o João (já) tinha arrumado a casa.

Em todas as sentenças acima, o tempo de referência é passado. A diferença entre (51a), (51b) e (51c) está na relação entre a eventualidade de o João arrumar a casa e esse tempo de referência. Os exemplos (51a) e (51b) são opostos nesse sentido: na primeira sentença, a eventualidade se perfaz dentro do tempo de referência, enquanto no segundo exemplo, o tempo de referência parece ser mais curto que a eventualidade. Já no exemplo (51c), a eventualidade já havia se completado antes mesmo do início do tempo de referência. As três sentenças podem ser visualmente representadas pelas linhas do tempo abaixo, nas quais os colchetes representam o tempo de referência, e a linha azul (_) representa a eventualidade.

(51) a. (Ontem à tarde,) o João arrumou a casa.

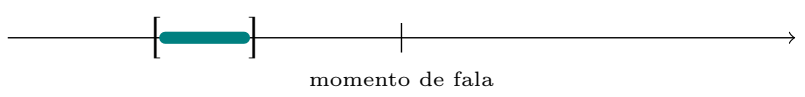

b. (Quando a Maria chegou,) o João estava arrumando a casa.

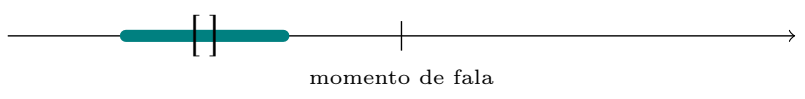

c. (Quando a Maria chegou,) o João (já) tinha arrumado a casa.

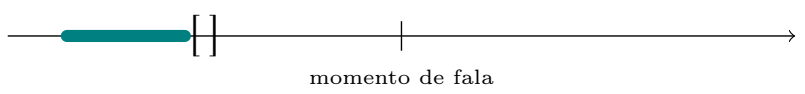

Segundo a versão da teoria referencial do tempo delineada em Kratzer (1998), os operadores responsáveis por situar eventualidades em relação a intervalos de tempo seriam os núcleos aspectuais. Sintaticamente, haveria uma projeção aspectual abaixo do TP (conforme mostrado na árvore (52)). Sintagmas verbais seriam então combinados com operadores aspectuais e serviriam de complemento ao núcleo temporal.

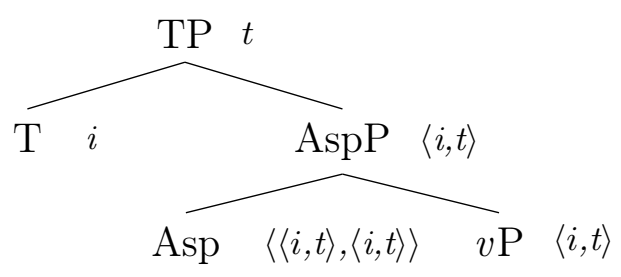


Baseando-se em Klein (2013) e Kratzer (1998), Ferreira (2017b) propõe as seguintes formalizações para os três principais núcleos aspectuais:
a. $\llbracket$ PERFECTIVO $\rrbracket=\lambda P . \lambda i . \exists i^{\prime}\left[i^{\prime} \subset i \& P\left(i^{\prime}\right)\right]$
b. $\quad$ IMPERFECTIVO $\rrbracket=\lambda P . \lambda i . \exists i^{\prime}\left[i \subseteq i^{\prime} \& P\left(i^{\prime}\right)\right]$
c. $\llbracket$ PERFEITO $\rrbracket=\lambda P . \lambda i . \exists i^{\prime}\left[i^{\prime}<i \& P\left(i^{\prime}\right)\right]$

De acordo com as entradas lexicais acima, os aspectos perfectivo e imperfectivo estabelecem relações de inclusão entre o tempo de ocorrência de uma eventualidade $\left(i^{\prime}\right)$ e o tempo de referência $g(i)$. Para que uma sentença no aspecto perfectivo seja julgada verdadeira, o tempo de duração da eventualidade deve estar contido no intervalo $g(i)$. Essa relação é invertida no caso do aspecto imperfectivo, que demanda que $i^{\prime}$ contenha $g(i)$. Já o aspecto perfeito implica uma eventualidade que tenha culminado antes do início de $g(i)$.

Voltando aos exemplos (51), agora podemos dizer que a sentença (51a) é a combinação entre um Tempo pretérito e um núcleo aspectual perfectivo. A sentença (51b) é a combinação entre um Tempo pretérito e um núcleo aspectual imperfectivo e, finalmente, a sentença (51c) é a combinação entre um Tempo pretérito e o aspecto perfeito. Utilizando as regras composicionais apresentadas até aqui e as entradas lexicais acima, somos capazes de chegar às condições de verdade adequadas para (51a):

(54) João arrumou a casa.

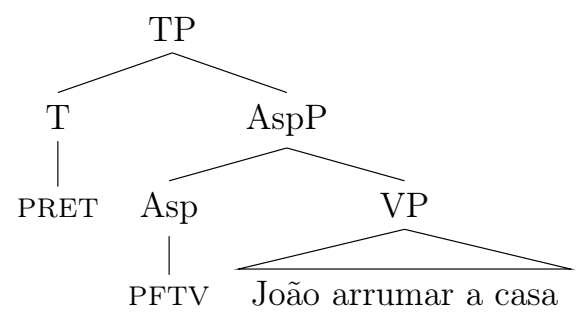

1. $\llbracket \mathrm{VP} \rrbracket^{g}=\llbracket[$ João arrumar a casa $] \rrbracket^{g}=$ $\lambda i$. João arruma a casa em $i$

2. $\llbracket \mathrm{Asp} \rrbracket^{g}=\llbracket \mathrm{PFTV} \rrbracket^{g}=\lambda P \cdot \lambda i \cdot \exists i^{\prime}\left[i^{\prime} \subset\right.$ $\left.i \& P\left(i^{\prime}\right)\right]$

3. $\llbracket \mathrm{T} \rrbracket^{g}=\llbracket \mathrm{PRET} \rrbracket^{g}=$ $\begin{cases}g(i) & \text { se } g(i)<\text { momento de fala } \\ \text { indefinido } & \text { nos demais casos }\end{cases}$

Por meio de aplicações funcionais sucessivas, obtemos:

1. $\llbracket \mathrm{AspP} \rrbracket^{g}=\llbracket \mathrm{Asp} \rrbracket^{g}\left(\llbracket \mathrm{VP} \rrbracket^{g}\right)=$

$\lambda P . \lambda i . \exists i^{\prime}\left[i^{\prime} \subset i \& P\left(i^{\prime}\right)\right](\lambda i$. João arruma a casa em $i)=$

$\lambda i . \exists i^{\prime}\left[i^{\prime} \subset i \&\right.$ João arruma a casa em $\left.i^{\prime}\right]$

2. $\llbracket \mathrm{TP} \rrbracket^{g}=\llbracket \mathrm{AspP} \rrbracket^{g}\left(\llbracket \mathrm{T} \rrbracket^{g}\right)=$

$\lambda i . \exists i^{\prime}\left[i^{\prime} \subset i \&\right.$ João arruma a casa em $\left.i^{\prime}\right](g(i))=1$ sse

$\exists i^{\prime}\left[i^{\prime} \subset g(i) \&\right.$ João arruma a casa em $\left.i^{\prime}\right]$

A partir das combinações possíveis entre tempos e aspectos, Kratzer (1998) mapeia os tempos verbais de algumas línguas, como ilustramos abaixo com o inglês: 


\begin{tabular}{l|ll} 
& Presente & Pretérito \\
\hline Imperfectivo & Present Progressive & Past Progressive \\
Perfectivo & Reporter's Present & Simple Past \\
Perfeito & Simple Past $^{28}$ & Simple Past ou Past Perfect
\end{tabular}

Quadro 1.1: Combinações de Tempo e aspecto no inglês (Kratzer (1998))

Na próxima seção, procuraremos identificar a expressão de cada combinação entre Tempo e aspecto no PB.

\subsubsection{Tempo e aspecto no português brasileiro}

Como já mostramos com os exemplos em (51), o modo indicativo do PB dispõe de três tempos verbais compostos por um intervalo de referência passado: o Pretérito Perfeito (51a), o Pretérito Imperfeito (51b) e o Pretérito Mais-que-perfeito (51c).

O Pretérito Imperfeito apresenta uma peculiaridade no PB. Sua forma sintética é utilizada com predicados estativos e habituais, mas não eventivos. Nesses casos, a forma preferível é a forma perifrástica de pretérito progressivo (Ferreira (2017b)):

(55) a. Quando eu conheci o João, ele morava no Rio.

estativo

b. Quando eu conheci o João, ele fumava. habitual

c. \# Quando eu conheci o João, ele arrumava a casa. eventivo

d. Quando eu conheci o João, ele estava arrumando a casa. eventivo

Quanto ao pretérito mais-que-perfeito, sua forma sintética caiu em desuso, tendo sido substituída pela perífrase ter+participio:

(56) a.\% Quando a Maria chegou, o João (já) arrumara a cara.

b. Quando a Maria chegou, o João (já) tinha arrumado a casa.

Núcleos temporais presentes formam o presente progressivo, quando se combinam com o aspecto imperfectivo, e o presente perfeito, quando se combinam com o aspecto perfeito. Esse último tempo verbal só está disponível no modo subjuntivo do PB:

(57) a. O João está arrumando a casa.

b. Espero que o João tenha arrumado a casa.

\footnotetext{
${ }^{28}$ Acreditamos que o Present Perfect também pode ser considerado a combinação entre um núcleo temporal presente e o aspecto perfeito.
} 
Seguindo Ferreira (2017b), assumiremos que, no modo indicativo, a ausência de uma forma dedicada à combinação presente+perfeito é suprida pelo pretérito perfeito. Esse tempo verbal seria ambíguo entre uma leitura de pretérito perfectivo e presente perfeito. Isso vai ao encontro da proposta de Kratzer (1998). A autora compara usos do past simple no inglês e no alemão e mostra que, no inglês, esse tempo verbal é aceitável mesmo quando utilizado repentinamente, sem que haja qualquer intervalo de tempo passado saliente no contexto. Em situações como essa, o present perfect é utilizado no alemão:
a. Who built this Church? Borromini built this church.
Quem construiu essa igreja? Borromini construiu essa igreja.
b. ${ }^{*}$ Wer baute diese Kirche? Borromini baute diese Kirche.
Quem construiu essa igreja? Borromini construiu essa igreja.
c. Wer hat diese Kirche gebaut? Borromini hat diese Kirche
Quem tem essa igreja construir.part? Borromini tem essa igreja gebaut.
construir.PART

O PB exibe um comportamento análogo ao do inglês. Ou seja, o pretérito perfeito é aceitável tanto em contextos repentinos, como (59a), quanto em contextos que fornecem um núcleo temporal pretérito, como (59b):

(59) a. Eu (já) visitei a China.

b. Eu visitei a China (nas últimas férias).

Finalmente, o PB também possui dois tempos verbais que localizam uma eventualidade em um tempo posterior ao do núcleo temporal: o futuro do presente e o futuro do pretérito $^{29}$ :

(61) a. O João vai arrumar a casa.

b. O João ia arrumar a casa (quando a Maria chegou).

Assumiremos que o futuro do presente e o futuro do pretérito são formados a partir da combinação entre um núcleo temporal presente / pretérito e um operador futuro, cuja contribuição semântica seria, em linhas gerais, a imagem espelhada do perfeito:

\footnotetext{
${ }^{29}$ Esses tempos verbais também apresentam uma forma sintética, que está caindo em desuso:

(60) a. O João arrumará a casa.

b. O João arrumaria a casa.
} 
(62) $\llbracket \mathrm{FUT} \rrbracket=\lambda P . \lambda i . \exists i^{\prime}\left[i^{\prime}>i \& P\left(i^{\prime}\right)\right]$

Resumindo o que foi discutido nesta seção, assumiremos a seguinte composição para o paradigma temporal do modo indicativo no PB:

\begin{tabular}{l|ll} 
& PRESENTE & PRETÉRITO \\
\hline IMPERFECTIVO & Presente progressivo & Pretérito imperfeito \\
PERFECTIVO & Reporter's present & Pretérito perfeito \\
PERFEITO & Pretérito perfeito & Pretérito mais-que-perfeito \\
FUtURO & Futuro do presente & Futuro do pretérito
\end{tabular}

Quadro 1.2: Combinações de Tempo e aspecto no PB

\footnotetext{
${ }^{30}$ Dado que o presente denota um intervalo de tempo curtíssimo, equivalente ao momento de fala, e que o aspecto perfectivo inclui uma eventualidade dentro desse intervalo, a combinação entre esses dois elementos é bastante rara. O reporter's present é utilizado predominantemente em narrações de esportes, por exemplo. Não incluiremos esse tempo verbal nas nossas análises.
} 


\section{Capítulo 2}

\section{Descrição dos dados}

Neste capítulo, faremos uma apresentação inicial das interações modal-temporais que servem de objeto para esta dissertação. Adotaremos os termos perspectiva e orientação temporal de Condoravdi (2002), com uma ressalva terminológica. Em seu estudo, Condoravdi (2002) descreve as possíveis perspectivas e orientações temporais como sendo presentes, passadas ou futuras. Ao adotarmos essa terminologia, descreveríamos todas as sentenças em (63), por exemplo, como tendo orientação passada.

(63) a. O João pode ter perdido o vôo.

b. O João devia morar longe da empresa.

c. O João (já) devia ter saído de casa quando você ligou.

Para os falantes de PB, no entanto, há uma diferença interpretativa bastante relevante entre esses exemplos. Essas três sentenças poderiam ser parafraseadas da forma que mostramos em (64):

(64) a. É provável que o João tenha perdido o vôo.

b. É provável que o João morasse longe da empresa.

c. É provável que o João já tivesse saído de casa quando você ligou.

Observe que as paráfrases de (64b) e (64c) estão no pretérito do subjuntivo, enquanto a paráfrase (64a) está no presente do subjuntivo. Note também que, se parafraseássemos (63b) da mesma maneira que parafraseamos (63a), mudaríamos o significado da sentença:

(65) É provável que o João tenha morado longe da empresa.

Para que a sentença (65) seja julgada verdadeira, basta que João tenha morado longe da empresa em algum momento anterior ao momento de fala. Para que (63b) seja julgada verdadeira, é necessário que João morasse longe da empresa em um ponto específico do 
passado saliente no contexto $^{1}$. Sendo assim, reservaremos o termo orientação passada para sentenças como (63b) e (63c), cujos prejacentes realmente parecem se referir a um intervalo passado, enquanto sentenças como (63a) serão descritas como casos de orientação temporal perfeita ${ }^{2}$.

O capítulo começa com uma descrição do paradigma de interpretações temporais de sentenças com modais epistêmicos (seção 2.1). Essa seção é dividida entre perspectiva temporal e orientação temporal (subseções 2.1 .1 e 2.1.2, respectivamente). A seção 2.2 discute as possibilidades temporais de sentenças com modais raiz. Essa seção também está dividida entre perspectiva (subseção 2.2.1) e orientação temporal (subseção 2.2.2). Os resultados do capítulo são resumidos em quadros na seção 2.3.

\subsection{Modais epistêmicos}

\subsubsection{Perspectiva temporal}

Como já foi observado diversas vezes na literatura ${ }^{3}$, a primeira questão digna de nota acerca da interpretação temporal de modais epistêmicos é o fato de que sua perspectiva temporal parece ser invariavelmente presente. Esse padrão é notado não apenas nas sentenças em que o modal está no presente, mas também naquelas em que o modal recebe morfologia de pretérito ou futuro.

Para o primeiro exemplo, suponha que Maria resolve visitar seu amigo, João, às três da tarde, numa quarta-feira. Após chegar em sua casa e tocar a campainha insistentemente por alguns minutos, Maria percebe que aquele é o horário de trabalho de seu amigo, e diz:

O João pode / deve / tem que estar no trabalho.

Ao dizer a sentença (66), a falante levou em conta seu estado epistêmico no momento de fala. A sentença poderia ser parafraseada como de acordo com o que eu sei agora, é possível / necessário que o João esteja no trabalho. Tratam-se de modais com perspectiva inequivocamente presente. Não há nada de surpreendente nesses exemplos, visto que a flexão temporal dos modais coincide com sua perspectiva.

O PB traz casos mais interessantes, em que modais epistêmicos recebem morfologia de pretérito e ainda assim mantém sua perspectiva presente, como é o caso do exemplo (68), no contexto (67):

(67) Contexto: Maria é gerente da empresa em Pedro trabalhou ano passado. Na época, Pedro chegava atrasado com frequência. Duvidando de sua dedicação ao

\footnotetext{
${ }^{1}$ Discutiremos nos capítulos 3 e 4 a fonte dessa diferença interpretativa.

${ }^{2}$ Sempre que julgarmos importante para a clareza de exposição, utilizaremos termos mais descritivos, como orientação de pretérito perfeito.

${ }^{3}$ Cf. Condoravdi (2002), Hacquard (2006), Demirdache e Uribe-Etxebarria (2010), entre outros.
} 
emprego, Maria resolveu demiti-lo. Hoje, ao analisar alguns registros do desempenho de Pedro, Maria notou que, apesar de seus constantes atrasos, ele era um funcionário excelente. Ao se deparar com essas novas evidências, Maria reconsidera sua constatação inicial.

(68) O Pedro devia morar muito longe da empresa.

Na sentença acima, a falante utilizou o verbo devia para reportar seu estado epistêmico no momento de fala. Logo, trata-se de uma sentença com perspectiva presente, a despeito da morfologia do modal. Na verdade, se a perspectiva do modal nessa sentença fosse passada, ela seria julgada falsa nesse contexto. Afinal, de acordo com o estado epistêmico passado da falante, o Pedro se atrasava com frequência por ser um funcionário relapso. A morfologia de pretérito imperfectivo no modal não parece ser capaz de influenciar sua perspectiva temporal.

Uma segunda configuração temporal com o modal no pretérito imperfectivo corrobora essa observação:

(69) A: Ontem eu passei no escritório do Pedro às 4 da tarde e ele não estava lá.

B: Ele (já) devia ter ido pra casa.

No exemplo (69), o falante baseia-se na evidência que ele tem no momento de fala (ou seja, o escritório vazio de Pedro) para expressar uma possibilidade sobre um momento passado. Embora, à primeira vista, a configuração temporal desse exemplo possa parecer igual à do exemplo (68), há uma diferença crucial entre as duas sentenças. Em (69), há uma camada extra de anterioridade em relação ao momento de fala. O falante não se refere apenas a um intervalo de tempo localizado no passado, mas ele também situa a eventualidade de o Pedro ir pra casa em um momento anterior a esse intervalo. Isso significa que o prejacente é interpretado como pretérito perfeito. Esse tempo verbal é composto por um núcleo temporal pretérito combinado com um núcleo aspectual perfeito. O aspecto perfeito é denotado pelo auxiliar ter, enquanto o único candidato possível para fornecer um núcleo temporal pretérito é o morfema afixado ao modal.

Até esse ponto, vimos casos em que o modal recebe flexão de presente e casos em que ele recebe flexão de pretérito imperfectivo. Para completarmos o paradigma tempo-aspectual do $\mathrm{PB}$, precisamos encontrar casos em que o modal receba morfologia de pretérito perfectivo e de futuro (do presente e do pretérito).

O pretérito perfectivo no PB bloqueia uma leitura epistêmica. Apenas a sentença (70b), cuja leitura é raiz, é uma paráfrase aceitável para a sentença (70):

(70) O João pôde fazer a prova em uma data alternativa. 
a.\# Pode ser que o João tenha feito a prova em uma data alternativa.

b. Foi permitido que o João fizesse a prova em uma data alternativa.

Já os exemplos em que o modal recebe morfologia de futuro corroboram a observação de que a marcação tempo-aspectual afixada aos epistêmicos não é capaz de manipular sua perspectiva:

(71) O trânsito está muito pesado. O João deverá se atrasar.

Novamente, o falante faz uma previsão sobre o futuro com base nas evidências que têm no momento da fala. Ao contrário de casos como (68) e (69), em que a marcação de pretérito no modal era obrigatória, nesse caso, a morfologia de futuro parece ser facultativa. As condições de verdade das sentenças (71) e (72) são idênticas. Nos dois casos, a perspectiva temporal é presente e a orientação é futura.

O trânsito está muito pesado. O João deve se atrasar.

A mesma opcionalidade é encontrada quando o modal está no futuro do pretérito, como (74), que pode ser formulada como (75) sem nenhum prejuízo semântico. ${ }^{4}$ Para a sentença (74), imagine que o falante B baseou sua resposta no observação de que está havendo um protesto em uma das vias de acesso ao seu escritório.

(74) A: Por que o João estava tão bem vestido ontem de manhã?

B: Ele deveria ter uma reunião com o chefe mais tarde.

(75) B: Ele devia ter uma reunião com o chefe mais tarde.

Esses casos em que o modal recebe morfologia de futuro são particularmente esclarecedores para a investigação sobre o perfil morfossintático dos prejacentes de verbos modais, discussão que deixaremos para a seção seguinte. A importância de exemplos como (71) e (74) para essa seção reside no fato de que, mesmo com marcação futura, modais epistêmicos mantém perspectiva presente.

A conclusão dessa seção foi que a morfologia tempo-aspectual afixada a modais epistêmicos não é capaz de afetar sua perspectiva temporal. Em sentenças com modais no presente, no pretérito imperfeito, no pretérito perfeito, no futuro do presente e no futuro

\footnotetext{
${ }^{4}$ Em sentenças com o futuro perifrástico, composto pelo auxiliar ir seguido pelo infinitivo, a morfologia de futuro também pode ser omitida sem alteração das condições de verdade:
}

(73) a. João vai se atrasar.

b. João irá se atrasar. 
do passado, modais epistêmicos sempre reportam o estado epistêmico presente de um falante. Na próxima seção, discutiremos nossas intuições acerca da orientação temporal desses modais.

\subsubsection{Orientação temporal}

Seguiremos agora para a descrição das possíveis configurações de orientação temporal que sentenças com modais epistêmicos podem assumir. Ou seja, nessa seção, concentraremos nossa atenção nos elementos temporal-aspectuais presentes no prejacente desses modais.

Começaremos com a descrição de sentenças com orientação temporal presente. Duas configurações aspectuais são capazes de gerar leituras de orientação presente: predicados estativos, como (76a), e predicados habituais, como (76b). Nos dois casos, o próprio modal precisa estar no presente.

(76) a. A loja ainda pode / deve estar aberta. (As luzes estão acesas.)

b. O João deve se exercitar bastante. (Ele tem uma resistência muito boa.)

Como já sugerimos anteriormente, configurações temporais que são normalmente chamadas de orientação passada, precisarão ser desdobradas em três outras categorias: orientação perfeita, orientação passada e orientação de pretérito perfeito. A orientação de perfeita emerge da combinação entre um modal no presente e a presença do auxiliar ter no prejacente:

(77) O Eduardo pode / deve ter ido mal na prova.

Uma orientação verdadeiramente passada, depende de dois ingredientes: (i) um modal no pretérito imperfectivo e (ii) um predicado estativo (78a) ou habitual (78b):

(78) a. A: Por que o Pedro chegou tão tarde na festa?

B: Ele devia estar preso no escritório.

b. A: Por que a Maria morava tão longe do centro da cidade?

B: Ela devia trabalhar naquela área.

Uma orientação de pretérito perfeito depende da associação dos ingredientes da orientação perfeita e da orientação passada. Ou seja, o modal deve estar no pretérito imperfectivo e o prejacente deve conter o auxiliar ter:

(79) Contexto: Um aluno precisa da assinatura de um professor de seu departamento. Sabendo que o professor normalmente trabalha até as cinco da tarde, o aluno passa em seu gabinete às $4 \mathrm{~h} 00$, mas o encontra vazio. No dia seguinte, o aluno decide 
verificar com a secretaria do departamento por que o professor não estava na sala às $4 \mathrm{~h} 00$ :

(80) Ele devia ter saído pra uma reunião.

Note que a sentença acima não é um caso de perspectiva passada e orientação passada. O falante em questão não está reportando seu estado epistêmico relativo ao momento em que o aluno passou no gabinete do professor, mas sim seu estado epistêmico no momento da fala. Afinal, no dia anterior, o secretário sequer sabia que o professor não estava em seu gabinete. As duas camadas de anterioridade dessa sentença dizem respeito à interpretação de seu prejacente: antes do momento de fala, o aluno passou no gabinete do professor, e antes disso, o professor saiu para uma reunião.

O último tópico dessa subseção serão os casos de orientação temporal futura em sentenças com modais epistêmicos. Como vimos no início desta seção, a orientação temporal presente emerge de predicados estativos ou habituais com modais no presente. Já a orientação futura surge, de maneira geral, com predicados eventivos, quando o modal está no presente:

(81) Pode / Deve chover hoje. O céu tá escuro.

Outra maneira de se obter uma orientação futura é através da adição de advérbios temporais em sentenças com predicados estativos:

O João pode / deve estar em uma reunião amanhã.

A marcação futura no modal, que mostramos ser opcional na subseção anterior, naturalmente também gera orientações futuras, tanto de futuro do presente quanto de futuro do pretérito. Isso é ilustrado por exemplos como (71) e (74), repetidos abaixo como (83) e (84):

(83) O trânsito está muito pesado. O João deve(rá) se atrasar.

(84) A: Por que o João estava tão bem vestido ontem de manhã?

B: Ele $\operatorname{dev}($ er)ia ter uma reunião com o chefe mais tarde.

A opcionalidade dessa marcação pode servir como indício de que ela é meramente expletiva. Até esse ponto, parece claro que a morfologia tempo-aspectual afixada aos modais epistêmicos contribui para o cálculo de sua orientação temporal. Se esse realmente é o caso, podemos fazer duas previsões: Em primeiro lugar, esperaríamos que sentenças com o modal no futuro possam ter orientação presente. Em segundo lugar, esperaríamos que 
sentenças com o modal no futuro do pretérito possam ter orientação de pretérito imperfectivo ou perfeito, a depender da presença do auxiliar ter. Vamos explorar a primeira previsão:

(85) \# A Maria deverá estar doente. Ela nunca falta à aula.

Supondo um contexto em que um colega de turma indaga outro sobre a ausência de Maria, a sentença (85) não funcionaria como resposta. Um cenário que privilegia uma orientação presente pede um modal sem morfologia de futuro. A segunda previsão também se mostra equivocada:

(86) A: Por que o Pedro chegou tão tarde na festa?

B:\# Ele deveria estar preso no escritório.

A leitura mais saliente para a resposta de B em (86) é uma leitura raiz, em que a morfologia de futuro do pretérito não recebe uma leitura temporal, mas contrafactual. Sendo assim, a sentença dita por $\mathrm{B}$ é inadequada como resposta à pergunta de $\mathrm{A}$. O mesmo é observado em exemplos com orientação de pretérito perfeito, como (80). A sentença (87), uma paráfrase tentativa de (80), mas com o modal no futuro do pretérito, remete a uma obrigação não-cumprida. Sua leitura é raiz e sua orientação é de presente perfeito.

(87) \# Ele deveria ter saído pra uma reunião.

Concluímos, com base nesses exemplos, que, embora a marcação de futuro possa ser omitida, ela tem uma contribuição semântica ${ }^{5}$. Antes de discutirmos os modais raiz, um último fato sobre a orientação futura dos epistêmicos é digno de nota.

\section{Necessidade epistêmica futura}

Em sentenças com o modal ter que, o único modal de necessidade do PB, orientadas para o futuro, uma leitura epistêmica é bloqueada. Imagine que a sentença (88) foi dita por um falante ao observar o céu muito nublado:

(88) \# Tem que chover amanhã.

A sentença (88) não seria aceita em um contexto que privilegie uma leitura epistêmica. Sua interpretação mais saliente parece ser bulética.

Esse comportamento poderia ser considerado idiossincrático, afinal, os demais modais aceitam uma leitura epistêmica mesmo quando orientados ao futuro. No entanto, alguns

\footnotetext{
${ }^{5}$ Discutiremos a natureza dessa marcação no capítulo 4, sobre a orientação temporal em sentenças modais.
} 
dados envolvendo a negação do modal existencial poder dão indícios de que essa restrição é sistemática.

O verbo poder tem uma particularidade em relação aos demais modais do PB: ele pode tomar escopo acima ou abaixo da negação mesmo em sua leitura epistêmica. Esse comportamento é ilustrado pelos exemplos em (89). Nos dois exemplos, a ordem de escopo da sentença é transparente: Na sentença (89a), a negação tem escopo sob o modal. Para que essa sentença seja verdadeira, basta que haja um mundo possível no domínio do modal em que Pedro não esteja em casa. Já a sentença (89b), em que a negação tem escopo sobre o modal, é mais exigente. Para que ela seja julgada verdadeira, não pode haver nenhum mundo possível no domínio do modal em que João esteja em casa.

(89) a. O Pedro pode não estar em casa. (Às vezes ele vai à academia nesse horário.)

b. O Pedro não pode estar em casa. (Eu acabei de vê-lo no escritório.)

Em sentenças orientadas para o futuro, apenas a ordem de escopo $\exists \neg$ gera uma leitura epistêmica:

(90) a. O Brasil pode não vencer o jogo.

b.\#O Brasil não pode vencer o jogo.

(91) a. O Pedro pode não chegar a tempo para a reunião.

b.\# O Pedro não pode chegar a tempo para a reunião.

A relevância de exemplos como (90) e (91) para a discussão sobre a orientação temporal dos epistêmicos está no fato de que $\neg \exists$ é logicamente equivalente a $\forall \neg$. Isso significa que as sentenças (90b) e (91b) também são asserções universais. Propomos então, que, qualquer que seja a fonte da restrição à orientação futura nesses exemplos ${ }^{6}$, ela é exatamente a mesma que no exemplo (88).

\subsection{Modais raiz}

\subsubsection{Perspectiva temporal}

Assim como fizemos com os modais epistêmicos, começaremos essa discussão com os casos mais simples, em que a perspectiva temporal é presente. Para a sentença (92), imagine que, em um certo dia, as estações de uma linha de metrô encontram-se em reformas. Para chegar aos seus destinos, os passageiros precisam pegar um ônibus:

\footnotetext{
${ }^{6}$ Apresentaremos nossa análise no capítulo 4.
} 
(92) Os passageiros com destino ao terminal Butantã devem / têm que pegar um ônibus neste Domingo.

Na sentença (92), que recebe uma leitura teleológica, a morfologia de presente simples afixada ao modal reflete sua perspectiva. Com os modais epistêmicos, a equivalência entre o tempo do modal e sua perspectiva temporal estava restrita a exemplos como (92). Com os modais raiz, por outro lado, parece haver uma correlação bem forte entre esses dois parâmetros. Esse comportamento fica evidente em sentenças no pretérito, como os exemplos em (93):

(93) a. Até 2004, os alunos podiam / deviam / tinham que pegar um ônibus para chegar à universidade. ${ }^{7}$

b. O João pôde / teve que fazer uma prova substitutiva para ser aprovado.

c. Antes daquela matéria, eu nunca tinha tido que estudar tanto para passar em uma prova.

A sentença (93a) têm perspectiva de pretérito imperfectivo, a sentença (93b) têm perspectiva de pretérito perfectivo e a sentença (93c) tem perspectiva de pretérito perfeito. A diferença interpretativa entre essas três sentenças é exatamente o que se nota em sentenças não-modalizadas nesses tempos verbais. As circunstâncias que entram para o cômputo da base modal de (93a) são interpretadas como sendo habituais, não restritas ao intervalo de referência provido pelo núcleo temporal da sentença. Já a sentença (93b) indica que as circunstâncias levadas em conta foram pontuais, ou seja, o tempo do modal está contido no intervalo de referência. Finalmente, em (93c), as circunstâncias relevantes (ou ausência delas) já haviam sido extintas antes do início do intervalo de referência.

Voltaremos nossa atenção agora a sentenças com modais raiz nos tempos indicativos futuros - futuro do presente e futuro do pretérito. Para a sentença (94), imagine que uma nova lei eleitoral tenha sido aprovada no Brasil. De acordo com essa nova lei, o voto deixa de ser facultativo para adolescentes entre 16 e 18 anos. A lei que serve como fonte de ordenação para a sentença (94) entrará em vigência após o momento de fala, logo, no cenário descrito, a perspectiva temporal da sentença é futura.

(94) A partir do ano que vem, menores de 18 anos deverão / terão que votar.

Já a sentença (95), que se refere a uma regra que entraria em vigor em um momento posterior a um intervalo de tempo passado. Logo, sua perspectiva pode ser descrita como perspectiva de futuro do pretérito.

\footnotetext{
${ }^{7}$ Em exemplos como (93a), optamos pela inclusão de um advérbio temporal topicalizado para enfatizar que a leitura pretendida para o pretérito imperfectivo é uma leitura estritamente temporal. No entanto, o advérbio não é indispensável para a obtenção dessa leitura.
} 
(95) Em 2014, foi anunciado que, no ano seguinte, os professores de linguística teriam que ministrar 12 horas de aulas semanais.

Novamente, nota-se a opcionalidade da marcação de futuro. As paráfrases em (96a) e (96b) preservam as condições de verdade dos exemplos (94) e (95), respectivamente.

(96) a. A partir do ano que vem, menores de 18 anos devem / têm que votar.

b. Em 2014, foi anunciado que, no ano seguinte, os professores de linguística tinham que ministrar 12 horas de aulas semanais.

Nessa seção, apresentamos exemplos e julgamentos que apontam para uma correlação entre a marcação tempo-aspectual afixada a modais raiz e a perspectiva temporal desses modais. Essa generalização vai de encontro às constatações sobre a perspectiva temporal dos modais epistêmicos, que parece ser presente mesmo em modais que recebem morfologia de pretérito ou futuro. Discutiremos agora a interpretação temporal dos prejacentes de modais raiz.

\subsubsection{Orientação temporal}

A marcação da orientação temporal dos modais raiz encontra diversos paralelos com os modais epistêmicos. A orientação presente, por exemplo, também emerge de prejacentes compostos por predicados estativos:

(97) Enquanto ele estava na faculdade, o João pôde / teve que morar no campus.

A sentença (97) se refere a uma permissão ou obrigação passada. O prejacente dessa sentença é interpretado em um momento concomitante à aplicação dessa regra. Trata-se de uma sentença com perspectiva de pretérito perfectivo e orientação presente.

Já o exemplo (98) se refere a uma norma vigente em uma universidade. Sua leitura é deôntica ${ }^{8}$, e sua perspectiva é presente. Sua orientação pode ser descrita como orientação perfeita, mas não passada.

(98) Para cursar Sintaxe II, os alunos podem / devem / têm que ter cursado Introdução à Linguística ou Sintaxe I.

De fato, orientações verdadeiramente passadas estão indisponíveis para os modais raiz:

\footnotetext{
${ }^{8}$ Também é possível argumentar que a interpretação dessa sentença é teleológica, afinal, os alunos devem ter cursado certas matérias para cumprir o objetivo de se matricular em Sintaxe II. Esse ponto é tangencial à nossa pesquisa. O que nos importa nesse exemplo é que sua base modal é circunstancial.
} 
(99) a. Os candidatos a essa vaga tinham que morar perto da empresa.

b. Para serem admitidos na pós-graduação, os candidatos tinham que ter obtido uma média ponderada acima de 6.0.

c. Para chegar ao seu destino, o João teve que viajar por várias horas.

Devido à variedade de noções normalmente veiculadas pela marcação de pretérito imperfectivo, as sentenças (99a) e (99b) são ambíguas entre pelo menos duas leituras. Em uma de suas leituras, o exemplo (99a) se refere a uma norma atualmente em vigência que especifica os requerimentos para os candidatos a uma certa vaga. Nesse caso, tanto a perspectiva quanto a orientação temporal são presentes. A marcação de pretérito imperfectivo em sentenças assim exerce a função de enfraquecer o modal de necessidade, como proposto por von Fintel e Iatridou (2008). Na segunda leitura, o pretérito imperfectivo no modal desempenha seu papel temporal. Nesse caso, a sentença se refere a circunstâncias passadas. A perspectiva é passada, e a orientação presente.

Com as devidas ressalvas, a mesma ambiguidade é notada na sentença (99b). Quando o pretérito imperfectivo não entra para o cálculo temporal da sentença, o modal ter que é interpretado como um modal de necessidade fraca cuja fonte de ordenação é uma norma em vigência em um certo programa de pós-graduação. A perspectiva temporal nesse caso é presente e a orientação é perfeita. Quando o pretérito imperfectivo é interpretado segundo sua leitura temporal, a sentença se refere às normas antigas de um programa de pós-graduação. Nesse caso, a perspectiva é de pretérito imperfectivo, e a orientação é perfeita.

Finalmente, a sentença (99c) se refere às circunstâncias no intervalo em que João viajou por várias horas, não no momento de fala. A perspectiva é passada e a orientação é presente. O ponto crucial dos exemplos em (99) é que nenhum deles é interpretado com perspectiva presente e orientação passada.

Quando a marcação afixada ao modal na sentença (100) é interpretada de maneira temporal, a sentença tem perspectiva de pretérito imperfectivo e orientação futura. Essa sentença seria julgada verdadeira se, por exemplo, ela se referisse às leis previdenciárias antigas.

(100) João não poderia se aposentar antes dos 65 anos.

Finalmente, sentenças em que modais raiz têm orientação futura também têm configurações morfossintáticas análogas às encontradas com modais epistêmicos. Ou seja, a orientação futura é obtida quando o prejacente contém um predicado eventivo, como ilustramos com a sentença (101a), ou quando o prejacente contém um predicado estativo ou habitual acompanhado de um advérbio temporal, como na sentença (101b). 
(101) a. Os alunos que obtiveram notas inferiores a 5.0 podem / devem / têm que fazer a prova de recuperação semana que vem.

b. Os alunos desse departamento têm que estar na reunião semestral semana que vem.

Com modais raiz, a distinção entre uma perspectiva futura e uma orientação futura é notadamente sutil. No entanto, acreditamos que, nos casos de modais raiz com orientação de futuro do presente, a marcação de futuro também é possível:

(102) a. Os alunos que obtiveram notas inferiores a 5.0 poderão / deverão / terão que fazer a prova de recuperação semana que vem.

b. Os alunos desse departamento terão que estar na reunião semestral semana que vem.

\subsection{Conclusão do capítulo}

Neste capítulo, apresentamos os dados e julgamentos que servirão de material empírico para as análises feitas nos capítulos seguintes. Na seção 2.1, discutimos a interpretação temporal de sentenças com modais epistêmicos. Os dados convergem para as seguintes generalizações:

\section{Generalizações sobre a interpretação temporal dos modais epistêmicos:}

(a) Tanto o núcleo temporal quando o núcleo aspectual adjungidos a um verbo modal epistêmico são incapazes de afetar a perspectiva temporal desse verbo, que é sempre o momento de fala;

(b) esses dois núcleos entram para o cálculo da orientação temporal de sentenças com modais epistêmicos;

(c) além da perspectiva temporal invariavelmente presente, existem duas outras restrições à interpretação temporal de modais epistêmicos:

i) o pretérito perfectivo bloqueia uma leitura epistêmica;

ii) a orientação futura não está disponível para asserções modais epistêmicas com força universal (ter que e poder sob o escopo da negação).

Na seção 2.2, discutimos interações entre tempo, aspecto e modais raiz no PB. De certa forma, a interpretação temporal de modais raiz parece espelhar a de modais epistêmicos. Isto é, enquanto os modais epistêmicos são compatíveis apenas com uma perspectiva presente, mas apresentam um paradigma de orientações temporais bastante rico, os modais 
raiz são compatíveis com perspectivas presentes ou passadas, mas não admitem orientações verdadeiramente passadas.

\section{Generalizações sobre a interpretação temporal dos modais raiz:}

(a) Existe uma forte correlação entre a marcação tempo-aspectual afixada ao modal raiz e sua perspectiva temporal;

(b) a orientação temporal de modais raiz emerge apenas das características aspectuais de seus prejacentes.

As tabelas 2.1 e 2.2 trazem resumos dos perfis morfossintáticos que geram cada possibilidade de interpretação temporal em sentenças com modais epistêmicos e raiz, respectivamente. 
Configuração morfossintática

\begin{tabular}{|c|c|c|}
\hline \multirow{3}{*}{$\begin{array}{l}\text { Perspectiva } \\
\text { temporal }\end{array}$} & Presente & modal $_{\text {PRES }}$ / PRET.IMP / FUt.PRES / FUT.PRET \\
\hline & Passada & $\#$ \\
\hline & Futura & \\
\hline \multirow{7}{*}{$\begin{array}{l}\text { Orientação } \\
\text { temporal }\end{array}$} & Presente & modal + oração infinitival com predicado estativo / habitual \\
\hline & Perfeita & modal + aux. ter + oração participial \\
\hline & Futura & $\begin{array}{l}\text { modal }_{\text {PRES } / \text { FuT.PRES }}+\text { oração infinitival com predicado eventivo / estativo } \\
\text { com advérbio temporal }\end{array}$ \\
\hline & Passada & modal $_{\text {РREт.IMP }}+$ oração infinitival com predicado estativo / habitual \\
\hline & Pretérito perfeito & $\#$ \\
\hline & $\begin{array}{l}\text { Pretérito } \\
\text { mais-que-perfeito }\end{array}$ & modal $_{\text {PRET.IMP }}+$ aux. ter + oração participial \\
\hline & Futuro do pretérito & $\begin{array}{l}\text { modal }_{\text {PRET.IMP } / \text { FUT.PRET }}+\text { oração infinitival com predicado eventivo / } \\
\text { estativo com advérbio temporal }\end{array}$ \\
\hline
\end{tabular}

Quadro 2.1: Interpretação temporal de sentenças com modais epistêmicos 
Configuração morfossintática

\begin{tabular}{|c|c|c|}
\hline \multirow{6}{*}{$\begin{array}{l}\text { Perspectiva } \\
\text { temporal }\end{array}$} & Presente & modal $_{\text {PRES }}$ \\
\hline & Futura & modal $_{\text {PRES }} /$ FUT.PRES \\
\hline & Passada & modal $_{\text {PRET.IMP }}$ \\
\hline & Pretérito perfeito & modal $_{\text {PRET.PFTV }}$ \\
\hline & $\begin{array}{l}\text { Pretérito } \\
\text { mais-que-perfeito }\end{array}$ & aux. ter $_{\mathrm{PRET} . \mathrm{IMP}}+$ modal $_{\mathrm{PART}}$ \\
\hline & Futuro do pretérito & modal $_{\text {PRET.IMP/FUT.PRET }}$ \\
\hline \multirow{4}{*}{$\begin{array}{l}\text { Orientação } \\
\text { temporal }\end{array}$} & Presente & modal + oração infinitival com predicado estativo / habitual \\
\hline & Perfeita & modal + aux. ter + oração participial \\
\hline & Futura & $\begin{array}{l}\text { modal }_{\text {PRES/FUT.PRES }}+\text { oração infinitival com predicado eventivo / estativo } \\
\text { com advérbio temporal }\end{array}$ \\
\hline & Passada & $\#$ \\
\hline
\end{tabular}

Quadro 2.2: Interpretação temporal de sentenças com modais raiz 


\section{Capítulo 3}

\section{Perspectiva temporal}

Neste capítulo, discutiremos como os verbos modais do PB fixam sua perspectiva temporal. Embora essa discussão possa parecer trivial à primeira vista, ela torna-se mais complicada pelas observações frequentes na literatura sobre as diferenças interpretativas entre modais raiz e epistêmicos. Como vimos no capítulo 2, modais epistêmicos parecem sempre ter perspectiva presente, ao passo que modais raiz também apresentam perspectiva passada e futura. É necessário conciliarmos essa constatação com o caráter unificador do quadro teórico Kratzeriano. Ou seja, precisamos acomodar a forma diferente como modais interagem com o núcleo temporal da sentença sem que, para isso, tenhamos que adotar entradas lexicais distintas para modais epistêmicos e raiz.

O capítulo está organizado da seguinte forma: Na seção 3.1, revisaremos os dados relevantes para a discussão, incluindo dados de outras línguas. Na seção 3.2, apresentaremos estudos anteriores sobre a perspectiva temporal de verbos modais. Na seção 3.3, discutiremos como os dados do PB podem contribuir para o entendimento da fixação da perspectiva temporal de modais. Na seção 3.4, apresentaremos algumas abordagens sintáticas que procuram explicar uma aparente discrepância morfossemântica em sentenças com modais epistêmicos. Os resultados obtidos são condensados na seção 3.5. Salientamos que, como perspectiva e orientação temporal são intimamente relacionadas, uma análise formal composicional do comportamento temporal de sentenças modais será apresentada apenas no capítulo 4.

\subsection{Revisão de dados}

Modais raiz apresentam bastante flexibilidade em relação à perspectiva temporal que podem assumir. Nos exemplos repetidos abaixo, a perspectiva dos modais corresponde exatamente à morfologia flexional que receberam:

(103) a. Os passageiros com destino ao terminal Butantã devem / têm que pegar um ônibus. 
b. Até 2004, os alunos podiam / deviam / tinham que pegar um ônibus para chegar à universidade.

c. O João pôde / teve que fazer uma prova substitutiva para ser aprovado.

d. Antes daquela matéria, eu nunca tinha tido que estudar tanto para passar em uma prova.

e. A partir do ano que vem, menores de 18 anos deverão / terão que votar.

Sentenças nas quais o modal recebe morfologia de pretérito imperfectivo ou futuro do pretérito se comportam de maneira inesperada. Em todos os exemplos abaixo, a perspectiva temporal é presente, apesar da marcação temporal pretérita ou futura dos verbos $^{1}$ :

(104) a. A temperatura bem que pod(er)ia cair um pouco...

b. O João já dev(er)ia estar aqui.

c. Você $\operatorname{dev}(\mathrm{re})$ ia chegar um pouco antes do início do expediente.

No entanto, sentenças como aquelas em (104) não são um contraexemplo à generalização de que verbos modais raiz fixam sua perspectiva a partir do núcleo temporal e aspectual de uma sentença. A marca que os modais recebem nessas sentenças, chamada por von Fintel (2017) de marcação x, é conhecida pela variedade de noções que ela pode exprimir, e, em nenhuma dessas sentenças, ela é interpretada de maneira estritamente temporal. Em (104a), a marcação $x$ expressa que o falante quer que chova ${ }^{2}$. Em (104b), ela expressa contrafactualidade ${ }^{3}$. Em (104c), ela enfraquece o modal, como proposto por von Fintel e Iatridou (2008). Ao longo desta dissertação, nos concentraremos apenas nos usos temporais do pretérito imperfectivo e do futuro do pretérito. Dessa forma, a generalização sobre como modais raiz fixam sua perspectiva temporal é a seguinte:

\section{(105) Generalização I}

A perspectiva temporal dos modais raiz é determinada a partir do núcleo temporal e aspectual da sentença.

Modais epistêmicos, por outro lado, são notáveis por manterem uma perspectiva sempre presente - isto é, esses modais sempre reportam o estado epistêmico de um falante no momento de fala. Poderíamos propor ingenuamente que essa restrição a perspectivas passadas ou futuras é de natureza cognitiva. Se esse fosse realmente o caso, esperaríamos

\footnotetext{
${ }^{1}$ No capítulo 4, discutiremos uma possível explicação para a intercambialidade entre esses dois tempos verbais.

${ }^{2}$ Cf. Pessotto (2011) e Pires de Oliveira e Pessotto (2010) para uma investigação sobre a emergência da implicatura de desejo em modais no PB.

${ }^{3}$ Cf. Ferreira (2016) para uma discussão sobre os ingredientes da imperfectividade em sentenças contrafactuais.
} 
que todas as formas de expressão da modalidade epistêmica estivessem sujeitas à mesma restrição. Essa previsão mostra-se equivocada:

(106) a. Semana que vem saberemos o sexo do bebê.

b. Eu achava que era boa de Matemática.

Na sentença $(106 a)^{4}$, com o verbo de atitude proposicional saber, os falantes se referem ao seu estado epistêmico na semana seguinte. Já no exemplo (106b), o falante utiliza o verbo de atitude proposicional achar para reportar seu estado epistêmico passado. Com verbos modais epistêmicos, por outro lado, a morfologia flexional adjungida ao modal não influencia sua perspectiva, que é presente em todos os exemplos abaixo, que são seguidos de paráfrases informais. Note que, no exemplo (108), no qual o modal recebe morfologia de pretérito, e no exemplo (109), no qual o modal recebe morfologia de futuro, apenas as paráfrases que fazem referência ao estado mental presente dos falantes são aceitáveis.

(107) O João deve estar trabalhando muito essa semana.

a. De acordo com o que eu sei agora, o João está trabalhando muito (essa semana).

(108) O João devia estar trabalhando muito semana passada.

a. De acordo com o que eu sei agora, o João estava trabalhando muito (semana passada).

b.\#De acordo com o que eu sabia semana passada, o João estava trabalhando muito (semana passada).

(109) O João deverá estar trabalhando muito (semana que vem).

a. De acordo com o que eu sei agora, o João estará trabalhando muito semana que vem.

b.\#De acordo com o que eu saberei semana que vem, o João estará trabalhando muito (semana que vem).

Essas evidências indicam que uma teoria baseada em restrições cognitivas levaria à sub-geração. A restrição à perspectiva passada ou futura realmente parece estar limitada ao domínio dos verbos modais. Trata-se de uma generalização bastante recorrente entre os estudos da interação tempo-modalidade. Stowell (2004), Hacquard (2006, 2009, 2010) e Laca (2018a), entre muitos outros autores, observaram o mesmo padrão no inglês, francês

\footnotetext{
${ }^{4}$ Agradeço ao Prof. Marcos Lopes por ter inspirado esse exemplo durante meu exame de qualificação.
} 
e espanhol, respectivamente. Nos exemplos abaixo, apesar da morfologia de pretérito, pretérito perfectivo e pretérito imperfectivo, a perspectiva das sentenças é presente:

Jack's wife couldn't be very rich.

jack-GEN esposa pode $\mathrm{PRET}_{\mathrm{P}}$ ser muito rica

'A esposa de Jack não poderia ser muito rica.' [Stowell (2004) - ex. (10b)]

(111) John put prendre le train, bien qu'il soit possible qu'il ne l'ait pas pris. john pôde pegar o trem, mas ele é possível que não tenha NEG pêgo

'Foi possível que o John pegasse o trem, mas talvez ele não tenha pego.'

[Hacquard (2010) - ex. (17)]

(112) María ya debería haber llegado a su casa.

maria já deveria haver chegado em sua casa

'A Maria já devia ter chegado em casa.' [ [Laca (2018a) - ex. (26)]

Apesar de diversos estudos apontarem para a perspectiva invariavelmente presente dos modais epistêmicos, esse ponto não é unânime entre pesquisadores. Na subseção seguinte, apresentaremos alguns exemplos bastante conhecidos na literatura que parecem apontar para uma possível perspectiva passada para essa classe de modais.

\subsubsection{Contraexemplos à perspectiva presente de modais epistê- micos}

Embora sejam minoria entre os estudos sobre modalidade, alguns trabalhos, como von Fintel e Gillies (2006, 2008) e Matthewson (2012, 2013) propõem que modais epistêmicos poderiam de fato admitir uma perspectiva passada. Para o exemplo (113), imagine que uma certa pessoa perde suas chaves e procura por elas numa gaveta. Após um certo tempo, essa pessoa nota que suas chaves estavam, na verdade, em seu bolso. Sua esposa então pergunta por que ele havia procurado por suas chaves na gaveta.

(113) The keys might have been in the drawer.

as chaves podiam ter estado na gaveta

'As chaves podiam estar na gaveta.' [von Fintel e Gillies (2006) - ex. (14)]

No contexto descrito, o falante tem conhecimento presente de que suas chaves não estão na gaveta, logo, a sentença $(113)^{5}$ não reporta seu estado epistêmico atual, mas

\footnotetext{
${ }^{5}$ Com predicados estativos, nos parece que a tradução mais natural para esse exemplo seja aquela apresentada na última linha de glosa, sem o auxiliar ter e um verbo no particípio.
} 
passado. Matthewson (2012) traz um exemplo similar. O contexto é o seguinte: um pai escuta seu filho celebrando na sala de estar enquanto assiste um jogo de seu time favorito. O pai deduz que esse time estivesse ganhando. No dia seguinte, o pai descobre que, na verdade, o time em questão estava perdendo de 0x20, e seu filho estava apenas rindo de algo que um amigo havia dito ${ }^{6}$.

$$
\begin{aligned}
& y u g w=i m a a=h l \quad x s d a a-d i i t . \\
& \mathrm{IMPF}=\mathrm{EPIS}=\mathrm{CN} \text { ganhar-3PL.II } \\
& \text { 'Eles podiam estar ganhando.' }
\end{aligned}
$$

Nossos julgamentos para as glosas desses exemplos em PB estão de acordo com o julgamento dos autores. No entanto, a validade dessas sentenças como contraexemplos à generalização de que epistêmicos sempre teriam perspectiva presente é um ponto controverso. Um primeiro problema com as sentenças (113) e (114) reside no fato de que, quando ditas fora de contexto, sua perspectiva temporal mais saliente é presente. Uma interpretação com perspectiva passada depende de um contexto propício, e normalmente só emerge como respostas a perguntas com por que.

A própria natureza epistêmica de exemplos como (113) é questionada por Abusch (2012). A autora propõe que seja possível modelar a semântica do modal em (113) a partir de uma base modal circunstancial e uma fonte de ordenação que codifique noções de melhor prática.

Hacquard (2006) sugere que essas sentenças possam ser interpretadas como orações encaixadas embaixo de um verbo de atitude proposicional que, por sua vez, estaria no passado. De acordo com essa solução, a morfologia de pretérito no verbo modal seria apenas um reflexo da morfologia do verbo que o controla, e o efeito de perspectiva passada seria, na verdade, um efeito de sequência de tempos. Os efeitos de sequência de tempos em sentenças com modais trazem alguns desafios próprios, que serão discutidos posteriormente nesse mesmo capítulo, mas se assumirmos a proposta de Hacquard (2006), a perspectiva do modal nos exemplos (113) e (114) poderia ser entendida como sendo concomitante ao agora de um pensamento passado:

(115) a. Eu achei que as chaves podiam estar na gaveta.

b. Eu achei que eles podiam estar ganhando.

Exemplos em que modais epistêmicos assumem uma perspectiva passada são escassos e dependem de algumas manobras pragmáticas para que a leitura desejada possa emergir. Ainda assim, a própria natureza epistêmica desses exemplos é questionável, e mesmo

\footnotetext{
${ }^{6}$ A tradução de Matthewson (2012) para esse exemplo é They might have been winning. Ou seja, essa sentença teria o mesmo perfil sintático-semântico que o exemplo (113). Nos parece que, no PB, a tradução mais natural para esses exemplos exclui o auxiliar do perfeito, have.
} 
que admitamos que esses exemplos são, de fato, epistêmicos com perspectiva passada, é possível recorrer à solução de Hacquard (2006) e tratar a perspectiva desses modais como um caso de sequência de tempos. Dessa forma, esses exemplos não nos parecem convincentes o bastante para motivar uma análise que permita essa relativa liberdade de perspectiva temporal a esses modais. No restante desse trabalho, assumiremos que modais epistêmicos sempre têm perspectiva presente:

\section{(116) Generalização II}

Modais epistêmicos em orações matriz sempre têm perspectiva temporal presente, independentemente da morfologia flexional afixada ao modal.

A conclusão dessa seção foi que existe uma assimetria entre a perspectiva temporal de modais epistêmicos e modais raiz. A perspectiva temporal dos modais raiz é sensível à morfologia flexional adjungida ao modal, ao passo que a perspectiva temporal dos epistêmicos é sempre presente. Na seção seguinte, discutiremos duas abordagens para a questão, e apresentaremos aquela que acreditamos ser mais adequada para explicar os dados do PB.

\subsection{Estudos anteriores}

A discussão sobre por que modais epistêmicos e modais raiz exibem um comportamento temporal distinto se resume, em grande parte, à altura desses modais na árvore. Alguns autores, como Condoravdi (2002), Matthewson (2012) e Laca (2018a) propõem que tanto modais raiz quanto modais epistêmicos seriam interpretados abaixo do núcleo temporal da sentença. Esses estudos serão discutidos na seção 3.2.1. Essa não é, contudo, uma abordagem majoritária. A maior parte dos estudos aponta para uma diferença de altura entre as duas classes de modais, com modais epistêmicos sendo interpretados acima do tempo, e, por conseguinte, tomando o momento de fala como sua perspectiva temporal. Esse grupo de estudos será discutido na seção 3.2.2.

\subsubsection{Modais abaixo do TP}

\section{Condoravdi (2002)}

Condoravdi (2002) concentrou sua análise nos modais não-raiz do inglês, ou seja, os epistêmicos e metafísicos. Partindo da generalização de que modais epistêmicos têm perspectiva sempre presente, Condoravdi (2002) propôs que esses modais fixam sua perspectiva temporal a partir do núcleo temporal das sentenças em que estão inseridos. Para explicar a impossibilidade de perspectivas passadas ou futuras, a autora postulou que, em sentenças com modais epistêmicos, o núcleo temporal seria sempre presente. 
A principal motivação de Condoravdi (2002) é o comportamento de modais epistêmicos em contextos intensionais. Nesses contextos, verbos modais se comportam exatamente como verbos não-modais, isto é, eles estão sujeitos ao fenômeno de sequência de tempos:

$$
\begin{aligned}
& \text { Caesar knew that his wife } \underline{\text { might be in Rome. }} \\
& \text { césar sabia que sua esposa podia estar em roma }
\end{aligned}
$$

Na sentença (117), o modal might / podia tem perspectiva passada em relação ao momento de fala, e presente em relação ao agora do verbo de atitude saber. Em outras palavras, nessa sentença, o modal não se refere à possibilidade da esposa de César estar em Roma no presente, mas no momento em que César soube dessa possibilidade. Isso significa que o passado marcado no modal não é de fato interpretado como um passado. Se esse fosse o caso, esperaríamos uma relação de precedência entre a perspectiva do modal e o agora do verbo de atitude.

Vale lembrar que, como expusemos no capítulo 1, seção 1.3, de acordo com uma versão da teoria referencial do tempo como aquela delineada em Kratzer (1998), a sequência de tempos é explicada pela existência de um tempo zero, que entra na derivação sem traços interpretáveis e herda a morfologia de um verbo que o antecede localmente. Para que um verbo esteja sujeito a esse fenômeno é necessário que ele esteja sob o escopo desse tempo zero. Parece natural, então, postular que, se o modal está sob o escopo de um tempo zero em contextos intensionais, ele também está sob o escopo de um tempo em contextos matriz. Sendo assim, Condoravdi (2002) propõe que verbos modais tomariam o núcleo temporal da sentença como argumento e o utilizariam para definir sua perspectiva temporal, como mostramos na entrada lexical abaixo, adaptada do exemplo (22) de Condoravdi $(2002)^{7}$.

$$
\llbracket \operatorname{might}_{\mathcal{F}, \mathcal{G}} \rrbracket=\lambda p \cdot \lambda w \cdot \lambda \boldsymbol{i} \cdot \exists w^{\prime}\left[w^{\prime} \in \operatorname{Best}_{\mathcal{G}(w, i)}(\cap \mathcal{F}(w, i)) \& P(w)\right]
$$

\section{Rullmann e Matthewson (2018)}

Rullmann e Matthewson (2018) conduziram um estudo translinguístico utilizando dados do inglês, holandês, gitksan e st'at'imcets. Os autores concluíram que a perspectiva temporal dos modais é sempre determinada pelo núcleo temporal da sentença, enquanto a orientação temporal é sempre determinada por operadores aspectuais sob o escopo do modal. Diferente dos outros estudos apresentados nessa subseção, Rullmann e Matthewson (2018) aceitam leituras de modais epistêmicos com perspectiva passada, o que os autores utilizam como evidência de que todos os modais têm escopo abaixo do tempo. Rullmann e Matthewson (2018) rejeitam a análise de Hacquard (2006) de que tais leituras seriam um

\footnotetext{
${ }^{7}$ Como ainda não discutimos como modais fixam sua orientação temporal, a entrada lexical foi simplificada, excluindo quaisquer operadores abaixo do escopo do modal.
} 
caso de sequência de tempos abaixo de uma oração matriz elidida. Seu contra-argumento é baseado em sentenças em inglês nas quais a ausência do auxiliar perfeito have impede a emergência de uma leitura de perspectiva passada. Segundo os autores, se Hacquard (2006) estivesse certa, esperaríamos uma perspectiva passada no exemplo (119), o que não ocorre:

\section{(119) I thought that my keys might be in there. eu achei que minhas chaves podiam estar em lá \\ 'Eu achei que minhas chaves podiam está lá.'}

A conclusão dos autores é de que a análise de Hacquard (2006) leva à supergeração, prevendo a existência de formas que não são atestadas na língua. É importante salientar, que, como dissemos anteriormente, a tradução de (119) para o PB não apenas dispensa o auxiliar ter como soa mais natural sem ele. Compare:

(120) Por que você estava revirando as gavetas?

a. Porque minhas chaves podiam estar lá.

b. ?Porque minhas chaves podiam ter estado lá.

Sendo assim, talvez essa linha de raciocínio se baseie apenas numa idiossincrasia do inglês, e não encontre um lastro translinguístico que a apoie.

Rullmann e Matthewson (2018) reconhecem ainda um potencial problema empírico para sua análise. Em determinados contextos, o semi-modal have to permite uma perspectiva temporal presente. Esse é o caso dos dois exemplos abaixo ${ }^{8}$ :

(121) Contexto: Até o momento, toda a evidência apontava para o fato de que Mary estava em casa na noite passada. Uma nova evidência, no entanto, sugere que a casa Mary estava vazia.

(122) Mary had to be out last night. maria tinha que estar fora última noite

'A Maria tinha que estar fora (de casa) na noite passada.'

(123) Contexto: Você está contando para alguém sobre quantas pessoas estavam numa festa que aconteceu noite passada. Você estava na festa e, enquanto ela ainda estava acontecendo, você achou que havia mais ou menos 50 pessoas lá. Mas hoje

\footnotetext{
${ }^{8}$ Exemplos (146) e (147) em Rullmann e Matthewson (2018).
} 
você foi limpar a casa e, baseando-se no número de copos sujos e outras evidências, você nota que, na verdade, devia haver pelo menos 100 pessoas lá.

(124) There had to be a hundred people there.

EXPL tinha que estar uma centena pessoas lá

'Tinha que haver umas cem pessoas lá.'

Tanto em (122) quanto em (124), a morfologia de passado no modal não parece afetar sua perspectiva temporal, mas sua orientação. Esses exemplos são dispensados por Rullmann e Matthewson (2018) como sentenças no máximo marginais. Na seção 3.3, ratificaremos que, no $\mathrm{PB}$, sentenças com esse perfil sintático-semântico são perfeitamente aceitáveis.

\subsubsection{Modais epistêmicos e raiz em alturas diferentes}

Uma linha de análise muito mais comum entre estudiosos da interação modalidade-tempo é a de que modais epistêmicos e modais raiz seriam interpretados em posições diferentes na árvore. Cinque (1999), um dos representantes mais proeminentes dessa linha de trabalhos, conduziu um estudo translinguístico sobre a ordem relativa de advérbios e propôs a existência de uma hierarquia fixa universal que determinaria a ordem de concatenação dos núcleos funcionais. A parte da Hierarquia de Cinque que nos é imediatamente relevante está resumida no diagrama arbóreo em (125):

\section{A Hierarquia de Cinque}

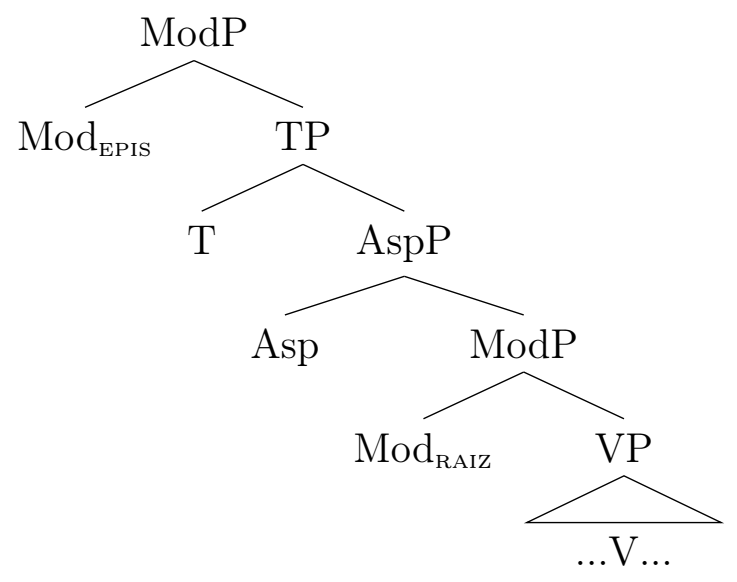

Como Hacquard (2006) aponta, embora a proposta de Cinque (1999) seja descritivamente adequada, ela carece de força explicativa. A primeira questão em aberto é: Por que modais epistêmicos têm escopo acima do tempo e do aspecto ao passo que modais raiz têm escopo acima do VP? Outra questão suscitada pela Hierarquia de Cinque (1999) 
diz respeito à semântica dos modais. A estrutura apresentada em (125) parece implicar tipos semânticos diferentes para cada classe de modais. Modais epistêmicos tomariam proposições como complemento, ao passo que modais raiz tomariam propriedades. Se desejamos manter o caráter unificador do quadro teórico Kratzeriano, essa constatação não é bem-vinda.

\section{Hacquard (2006)}

Com essas questões em mente, Hacquard (2006) se propôs a conciliar a Hierarquia de Cinque com a semântica Kratzeriana para verbos modais. A autora mostra, inclusive, que a diferença de altura sugerida por Cinque (1999) não se manifesta somente através da relação dos modais com o tempo: modais seriam ancorados também a indivíduos diferentes.

Baseada em suas diferentes combinações com indivíduos e tempos, Hacquard reconhece três grupos de modais, cujo comportamento é ilustrado pelos exemplos em $(126)^{9}$ :
a. John had to be home (at the time of the crime). joão tinha que estar casa (em o tempo de o crime)
'João tinha que estar em casa (no momento do crime).'
b. Mary thought that John had to be home. maria achou que joão tinha que estar casa
'A Maria achou que o João tinha que estar em casa.'
c. Mary had to take the train to go to Paris. maria teve que pegar o trem para ir para paris
'A Maria teve que pegar o trem para ir para Paris.'

A sentença (126a) poderia ser parafraseada como com base no que eu sei agora, o João tinha que estar em casa no momento do crime, ou seja, o modal se refere ao estado epistêmico presente do falante. No segundo exemplo, (126b), por outro lado, o modal expressa o estado epistêmico da Maria, a atittude holder, no momento em que ela indagava sobre João, ou seja, nesse caso, a perspectiva do modal é o momento da atitude. Finalmente, no último exemplo, o momento de avaliação do modal é passado, coincidindo com o tempo da sentença. A necessidade de pegar o trem está relacionada às circunstâncias do sujeito da sentença, Maria.

O padrão que emerge dos exemplos acima é o seguinte: Um modal epistêmico pode ser ancorado ao falante no momento de fala (como no exemplo (126a)), ou ao atittude holder no momento da atitude (como no exemplo (126b)). Um modal raiz, por sua vez,

\footnotetext{
${ }^{9}$ Exemplos (1), (2) e (3) em Hacquard (2010).
} 
é ancorado ao sujeito da sentença, e sua perspectiva é o tempo denotado pelo núcleo temporal. Ou seja, modais com interpretações diferentes não sofrem restrições apenas em relação à sua interação com o tempo, mas também à sua relação com indivíduos. Hacquard $(2006$, 2009, 2010) mostra que essas restrições recebem uma explicação natural se assumirmos que modais são relativos a eventos, não a mundos, afinal eventos são atribuídos de pares de indivíduos/tempos - isto é, seus participantes e tempos de duração. As diferentes alturas de interpretação decorreriam então dos diferentes eventos aos quais um modal pode ser relativizado.

Hacquard $(2006,2009$, 2010) conclui que o repertório de eventos aos quais um modal pode ser relativizado compreende o evento de fala, que ancora o modal ao falante e ao momento de fala; o evento de atitude, que ancora o modal ao atittude holder e ao momento da atitude; e o evento do VP, que ancora o modal ao sujeito e ao intervalo temporal fornecido pelo núcleo temporal. Mantendo o espírito unificador do arcabouço teórico de Kratzer, Hacquard assume uma entrada lexical única para cada modal. Para derivar as diferenças sintáticas entre modais epistêmicos e raiz, a autora incorpora uma variável de evento, que precisa ser ligada localmente, à restrição dos modais:

$$
\begin{aligned}
& \text { a. } \llbracket \text { must } \rrbracket=\lambda p \cdot \lambda e . \forall w^{\prime} \in \operatorname{Best}_{\mathcal{G}(e)}(\bigcap \mathcal{F}(e)): p\left(w^{\prime}\right)=1 \\
& \text { b. } \llbracket \text { can } \rrbracket=\lambda p \cdot \lambda e \cdot \exists w^{\prime} \in \operatorname{Best}_{\mathcal{G}(e)}(\bigcap \mathcal{F}(e)): p\left(w^{\prime}\right)=1
\end{aligned}
$$

O evento que liga a variável $\boldsymbol{e}$ determina a posição em os modais serão interpretados. Um modal pode ser concatenado acima ou abaixo do núcleo temporal da sentença. Quando ele é concatenado na posição alta, ou seja, acima do tempo, há duas possibilidades de ligação: em contextos matriz, a variável de evento é ligada pelo binder default de evento, o que ancora o modal ao evento de fala; em orações encaixadas, ele é ligado pelo aspecto matriz que quantifica sobre o evento de atitude - o que liga a variável ao evento de atitude. Na posição baixa, ou seja, abaixo do núcleo temporal, a variável de evento é ligada pelo aspecto, o que ancora o modal ao evento do VP.

A proposta de Hacquard esbarra em um problema mecânico: como garantir que modais raiz e epistêmicos sejam concatenados em alturas distintas se os dois tomam como argumento uma proposição, que só é fornecida pelo TP? A solução da autora é que o núcleo aspectual seria gerado como um argumento do VP, e então movido para uma posição imediatamente abaixo do TP, deixando um vestígio do tipo $\varepsilon$, o tipo semântico dos eventos. Verbos ligariam esse vestígio, gerando sintagmas verbais do tipo $t$, o que garante aos modais as duas posições de concatenação cruciais para a teoria de Hacquard. Essa solução é ilustrada no diagrama (128): 
(128)

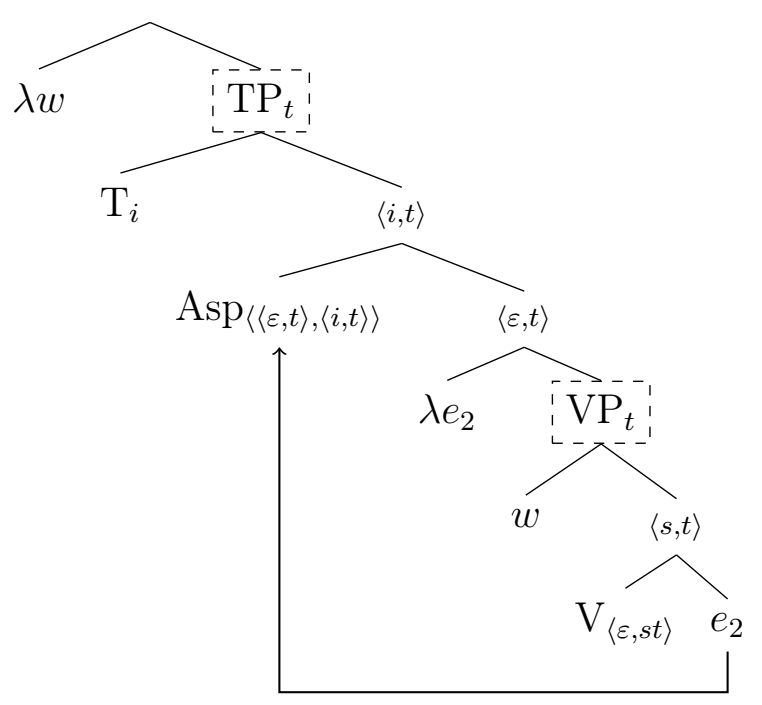

Tendo resolvido esse problema, a teoria de Hacquard (2006) ainda precisa explicar por que, exatamente, apenas modais que ligam o evento de fala ou o evento de atitude são interpretados como epistêmicos e por que modais que ligam o evento do VP recebem interpretações raiz. Segundo a autora, a resposta a essa questão está na própria natureza da modalidade epistêmica. A modalidade epistêmica se refere a um estado de informação (informative state no original), que só é fornecido pelos eventos altos. O evento do VP é desprovido desse conteúdo, o que o torna incapaz de licenciar uma base modal epistêmica.

Ao relativizar modais a eventos, Hacquard (2006) não só conseguiu capturar a diferença de altura entre modais raiz e epistêmicos a partir de uma entrada lexical única, como também motivar a co-variação entre altura e base modal. Na subseção seguinte, apresentaremos uma abordagem mais recente baseada numa ontologia isenta de eventos.

\section{Ferreira (2018)}

Assim como a teoria de Hacquard (2006), a proposta de Ferreira (2018) também busca aliar a diferença de altura entre modais epistêmicos e raiz aos pressupostos Kratzerianos. O autor também assume uma entrada lexical única, do tipo $\langle\langle s,\langle i, s t\rangle\rangle,\langle\langle s, t\rangle,\langle i, s t\rangle\rangle\rangle$, para cada modal. Note que as entradas lexicais abaixo tomam quatro argumentos: uma relação de acessibilidade $R$, responsável por restringir o domínio de quantificação do modal, uma proposição, um intervalo de tempo e um mundo possível:

$$
\begin{aligned}
& \text { a. } \quad \llbracket \text { poder } \rrbracket=\lambda R_{\langle s,\langle i, s t\rangle\rangle} \cdot \lambda p_{\langle s, t\rangle} \cdot \lambda i \cdot \lambda w \cdot \exists w^{\prime}\left[R(w)(i)\left(w^{\prime}\right)=1 \& p\left(w^{\prime}\right)=1\right] \\
& \text { b. } \quad \llbracket \text { ter que } \rrbracket=\lambda R_{\langle s,\langle i, s t\rangle\rangle} \cdot \lambda p_{\langle s, t\rangle} \cdot \lambda i \cdot \lambda w \cdot \forall w^{\prime}\left[R(w)(i)\left(w^{\prime}\right)=1 \longrightarrow p\left(w^{\prime}\right)=1\right]
\end{aligned}
$$

A relação de acessibilidade $R$, por sua vez, toma como argumento um par de mundo possível e intervalo de tempo e retorna uma proposição: 
(130) a. $\quad R_{\text {epis }}(w)(i)\left(w^{\prime}\right)=1$ iff $w^{\prime}$ é compatível com a evidência em $w$ at $i$

b. $\quad R_{\text {circ }}(w)(i)\left(w^{\prime}\right)=1$ iff $w^{\prime}$ é compatível com as circunstâncias em $w$ at $i$

A proposta central de Ferreira (2018) é que bases modais seriam introduzidas por modificadores presentes na sintaxe. Esses modificadores tomam um verbo modal como argumento e retornam um novo verbo modal, cujo tipo semântico depende da natureza da base modal. Um modificador epistêmico (EPIS), por exemplo, introduz um elemento indexical $\tau_{g}$ que corresponde à coordenada temporal de um certo contexto - em orações matriz, $\tau_{g}$ é o momento de fala. Um modificador circunstancial (CIRC) não tem esse elemento indexical, o que é uma forma engenhosa de capturar o fato de que modais raiz utilizam o núcleo temporal que os comanda para definir sua perspectiva temporal.

$$
\begin{aligned}
& \text { a. } \left.\quad \llbracket \mathrm{EPIS} \rrbracket^{g}=\lambda Q_{\langle\langle s,\langle i, s t\rangle\rangle,\langle\langle s, t\rangle,\langle i, s t\rangle\rangle\rangle} \cdot \lambda p_{\langle s, t\rangle} \cdot \lambda w \cdot Q\left(R_{\mathrm{epis}}\right)(p)\left(\tau_{c}\right)(w)=1\right] \\
& \text { b. } \left.\quad \llbracket \mathrm{CIRC} \rrbracket=\lambda Q_{\langle\langle s,\langle i, s t\rangle\rangle,\langle\langle s, t\rangle,\langle i, s t\rangle\rangle\rangle} \cdot \lambda P_{\langle i, s t\rangle} \cdot \lambda i \cdot \lambda w \cdot Q\left(R_{\text {circ }}\right)(P(i))(i)(w)=1\right]
\end{aligned}
$$

O segundo argumento desses modificadores também tem um tipo diferente dependendo do sabor modal. O modificador circunstancial pede um argumento do tipo $\langle i, s t\rangle$, i.e., um complemento que ainda não foi saturado por um intervalo temporal. O modificador epistêmico, por outro lado, se combina com um argumento de tipo $\langle s, t\rangle$, dado que o prejacente dos modais epistêmicos é encabeçado por um tempo referencial. Quando esses modificadores são aplicados a um verbo modal, nós obtemos entradas lexicais específicas para cada classe de modais a partir de entradas lexicais originalmente idênticas:
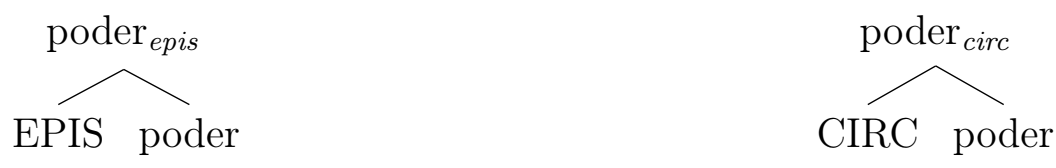

(134) Modais epistêmicos

$\llbracket$ poder $_{\text {epis }} \rrbracket^{c}=\llbracket$ EPIS $\rrbracket^{c}\left(\llbracket\right.$ poder $\left.\rrbracket^{c}\right)$

$\llbracket$ poder $_{\text {epis }} \rrbracket^{c}=\lambda p_{\langle s, t\rangle} \cdot \lambda w \cdot \exists w^{\prime}\left[R_{\text {epis }}(w)\left(\tau_{c}\right)\left(w^{\prime}\right)=1 \& p\left(w^{\prime}\right)=1\right]$

$\llbracket$ poder $_{\text {epis }} \rrbracket^{c}=\lambda p_{\langle s, t\rangle} \cdot \lambda w \cdot \exists w^{\prime}\left[w^{\prime}\right.$ é compatível com as evidências em $w$ em $\tau_{c} \&$ $\left.p\left(w^{\prime}\right)=1\right]$

\section{(135) Modais raiz}

$\llbracket$ poder $_{\text {circ }} \rrbracket=\llbracket \mathrm{CIRC} \rrbracket(\llbracket$ poder $\rrbracket)$

$\llbracket \operatorname{poder}_{c i r c} \rrbracket=\lambda P_{\langle i, s t\rangle} \cdot \lambda i \cdot \lambda w \cdot \exists w^{\prime}\left[R_{\text {circ }}(w)(i)\left(w^{\prime}\right)=1 \& P(i)\left(w^{\prime}\right)=1\right]$

$\llbracket$ poder $_{\text {circ }} \rrbracket=\lambda P_{\langle i, s t\rangle} \cdot \lambda i \cdot \lambda w \cdot \exists w^{\prime}\left[w^{\prime}\right.$ é compatível com as circunstâncias em $w$ em $i$ $\left.\& P(i)\left(w^{\prime}\right)=1\right]$ 
Guardadas as diferenças entre as propostas de Ferreira (2018) e Hacquard (2006), os dois trabalhos assumem que modais epistêmicos e raiz estabelecem relações de escopo distintas com o núcleo temporal e capturam essa diferença de altura sem abrir mão de uma entrada lexical única para cada modal, mantendo o espírito da semântica Kratzeriana para modais.

\subsubsection{Resumo da seção}

Esta seção teve como objetivo apresentar as propostas disponíveis para lidar com a questão da perspectiva temporal de modais. A revisão de literatura que fizemos aqui não foi de forma alguma exaustiva. Os trabalhos sobre a interação entre modalidade o tempo se proliferaram de maneira extremamente rápida nas últimas duas décadas e muitos dos estudos que surgiram têm tamanha semelhança com estudos anteriores que sua presença nessa seção seria injustificada. Nossa intenção foi apresentar propostas particularmente bem-elaboradas que servem como representantes de certas visões entre estudiosos.

Antes de resumirmos as propostas apresentadas, devemos mencionar uma análise menos comum na literatura: a de modais epistêmicos e modais raiz estão em alturas diferentes da árvore, mas o núcleo funcional relevante para essa diferença é o aspecto, não o tempo. Para os autores que adotaram essa linha de análise, entre os quais podemos citar Laca (2018b) e Demirdache e Uribe-Etxebarria (2010), modais epistêmicos seriam interpretados abaixo do TP e acima do AspP, enquanto modais raiz seriam interpretados abaixo de AspP.

A motivação de Laca (2018b) para propor que modais epistêmicos seriam interpretados abaixo do escopo do tempo é a mesma de Condoravdi (2002), ou seja, o comportamento de modais epistêmicos em contextos intensionais. A esse argumento, a autora adiciona a observação frequente na literatura de que apenas modais raiz com morfologia perfectiva geram actuality entailment ${ }^{10}$. No exemplo $(136)^{11}$, o modal pouvoir, em sua leitura raiz, leva à inferência não-cancelável de que a proposição sob o escopo do modal se perfez no mundo real. Esse efeito está ausente no exemplo $(137)^{12}$, no qual a leitura mais saliente para o modal é epistêmica ${ }^{13}$

(136) Jane put soulever cette table, (\# mais elle ne la souleva pas.) jane pôde levantar essa mesa, (\# mas ela NE a levantou não)

'A Jane pôde levantar essa mesa, (\# mas ela não a levantou.)'

\footnotetext{
${ }^{10}$ Termo proposto por Bhatt (1999).

${ }^{11}$ Exemplo (13a) em Hacquard (2010).

${ }^{12}$ Exemplo (13b) em Hacquard (2010).

${ }^{13}$ No PB, a morfologia perfectiva bloqueia uma leitura epistêmica, logo não é possível formular uma glosa para esse exemplo utilizando um modal no modo indicativo.
} 
Jane pouvait soulever cette table, (mais elle ne l'a pas soulevée). jane pode levantar essa mesa, (mas ela NE a levantou não)

'Foi possível que a Jane levantasse a mesa, (mas ela não a levantou).'

A combinação desses dois efeitos leva Laca (2018b) a propor que, embora haja uma diferença de altura entre modais raiz e modais epistêmicos, essa diferença de altura se dá com respeito ao núcleo aspectual, não ao núcleo temporal. A perspectiva normalmente presente dos modais epistêmicos seria explicada através de mecanismos semânticos e pragmáticos (Laca, c.p.), mas a autora não especifica o comportamento desses mecanismos.

Com essa última adição, as abordagens apresentadas nessa seção podem ser divididas em dois grandes grupos. O primeiro grupo compreende as propostas que localizam modais raiz e modais epistêmicos na mesma posição - abaixo do TP. De acordo com essas análises, as duas classes de modais se comportariam de maneira idêntica em relação à fixação de sua perspectiva temporal. Dentro desse primeiro grupo de trabalhos, cabe ainda uma subdivisão. Alguns autores, como Rullmann e Matthewson (2018), reconhecem a legitimidade de sentenças com o perfil de (113) enquanto exemplos de modais epistêmicos com perspectiva passada. Nesse caso, a discussão sobre perspectiva temporal se torna bastante simplificada, pois modais raiz e epistêmicos exibiriam o mesmo comportamento temporal. Outros autores, como Condoravdi (2002), assumem que modais epistêmicos teriam sempre perspectiva presente. A autora captura essa rigidez dos modais epistêmicos postulando que os núcleos temporais que os dominam sempre seriam presentes.

O segundo grupo de estudos representa a visão predominante entre estudiosos da interação entre modalidade e tempo. Autores como Hacquard (2006) e Ferreira (2018) assumem que modais epistêmicos são concatenados acima do núcleo temporal das sentenças, ao passo que modais raiz são concatenados acima do VP. Laca (2018b) também assume uma diferença de altura entre modais raiz e epistêmicos, mas essa diferença se daria com respeito ao núcleo aspectual da sentença, não ao núcleo temporal. Abordagens pertencentes a esse segundo grupo são particularmente desafiadoras, pois elas precisam garantir que as duas classes de modais tomem argumentos de tipos diferentes sem codificar essas diferenças lexicalmente. Apresentamos duas teorias bem-sucedidas nesse sentido: a teoria de Hacquard (2006), baseada em uma ontologia com eventos e intervalos de tempo; e a teoria de Ferreira (2018), baseada em uma ontologia dotada apenas de intervalos de tempo.

Essas abordagens são resumidas nos diagramas simplificados abaixo: 
Modais epistêmicos e raiz na mesma altura

(138) Condoravdi (2002)

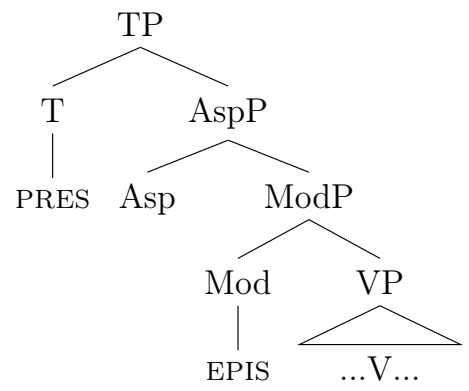

(139) Rullmann e Matthewson (2018)

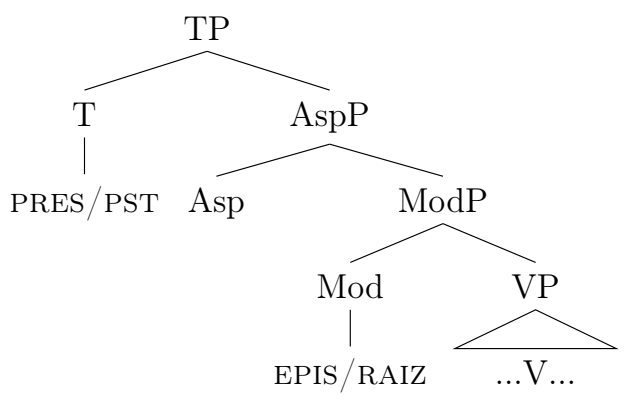

Modais epistêmicos acima de modais raiz

(140) Hacquard (2006)

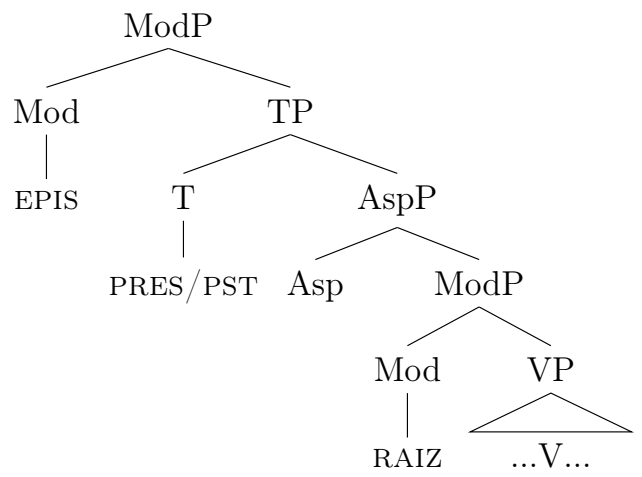

(141) Laca (2018b)

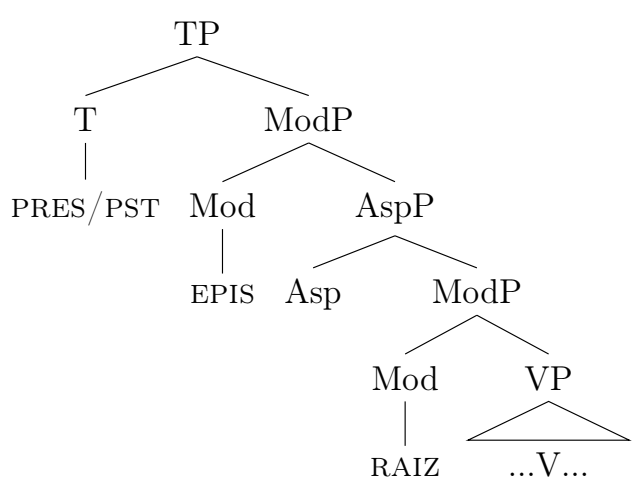

(142) Ferreira (2018)

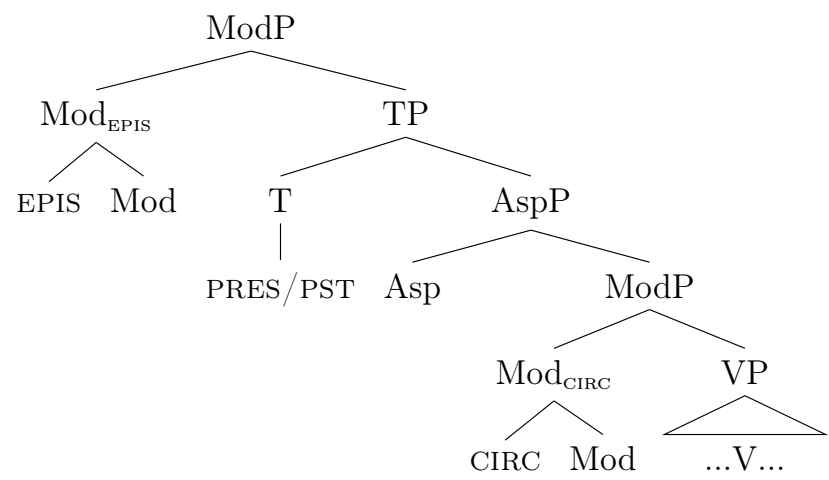

\subsection{As evidências do português brasileiro}

Como vimos no capítulo 2, os dados do PB corroboram a abordagem mais tradicional para a fixação da perspectiva temporal de modais, isto é, a posição que defenderemos 
nessa dissertação é a de modais epistêmicos são concatenados acima do tempo e aspecto, e modais raiz são concatenados abaixo desses núcleos funcionais.

\subsubsection{Modais epistêmicos podem ter perspectiva passada?}

O primeiro fator a ser levado em consideração é a disponibilidade de uma perspectiva passada para modais epistêmicos. Sentenças como (113), repetida abaixo como (143), têm sido usadas por pesquisadores como evidência de que modais epistêmicos podem assumir uma perspectiva passada, e por consequência, ocorrem abaixo do escopo do núcleo temporal.

$$
\begin{aligned}
& \text { The keys might have been in the drawer. } \\
& \text { as chaves podiam ter estado na gaveta }
\end{aligned}
$$

'As chaves podiam estar na gaveta.' [von Fintel e Gillies (2006) - ex. (14)]

No PB, nos parece que a leitura mais saliente para sentenças com esse perfil sintáticosemântico (modal EPIs $_{+}+$PRET.IMP + predicado estativo) é uma leitura com perspectiva presente e orientação passada. Considere esse mesmo exemplo no contexto abaixo:

(144) Contexto: Um casal está saindo de casa com pressa, e o marido não consegue encontrar suas chaves de maneira alguma. Após procurar no porta-chaves, no seu bolso, e na própria fechadura, o marido desiste e pega uma chave reserva. Minutos depois, já no carro, o marido conta para sua esposa que não havia conseguido encontrar as chaves e lista os lugares nos quais havia procurado. A esposa responde:

(145) Suas chaves podiam / deviam estar na gaveta.

Nesse contexto, a falante utilizou as evidências disponíveis a ela no momento de fala, ou seja, o fato de que o marido não conseguiu encontrar as chaves e o fato de que elas não estavam em outros lugares prováveis, para especular sobre a localização das chaves em um momento do passado. Trata-se de um modal com perspectiva presente e orientação passada. Exploraremos a questão da orientação passada brevemente nessa mesma seção. O ponto crucial desse exemplo é que, sem certas manobras pragmáticas, sentenças como (143) não têm perspectiva passada, ao contrário do que alguns autores argumentam. Sendo assim, podemos assumir, seguindo Hacquard (2006), que a suposta perspectiva passada dessas sentenças envolve uma sequência de tempos abaixo de uma oração matriz elidida. 


\subsubsection{Tempo sob o escopo de modais epistêmicos}

Apenas a ausência de perspectivas passadas para modais epistêmicos não é um argumento forte o bastante para assumirmos que esses modais são concatenados acima do TP. Isso indica apenas que esses modais não podem estar abaixo do escopo de um tempo pretérito. Poderíamos ainda assumir, com Condoravdi (2002), que modais epistêmicos estão sempre abaixo do escopo de um tempo presente. O contra-argumento para essa proposta é bastante simples, e já deve estar claro para o leitor: modais com morfologia de pretérito também têm perspectiva presente, como mostramos no exemplo acima. Exemplos como (143) também nos protegem do argumento de que a marcação de pretérito nos modais não é mais semanticamente ativa ${ }^{14}$, o que significaria que (143) envolveria um T presente. Como vimos, o pretérito marcado no modal é interpretado, mas entra para o cálculo de sua orientação temporal, não de perspectiva.

De fato, este parece ser o argumento mais forte para propormos uma diferença de altura entre modais raiz e modais epistêmicos: a presença de um tempo referencial abaixo do escopo de modais epistêmicos. Lembre que Rullmann e Matthewson (2018) reconhecem essa possibilidade como sendo um contra-argumento à sua proposta de que modais epistêmicos são interpretados abaixo do tempo. Os autores, no entanto, descartam esse tipo de dado por questionarem sua gramaticalidade. Os falantes de PB que consultamos não julgaram sentenças como (146b) e (147b) (repetidas do capítulo 2) sequer como marginais.

(146) a. Contexto: Maria é gerente da empresa em Pedro trabalhou ano passado. Na época, Pedro chegava atrasado com frequência. Duvidando de sua dedicação ao emprego, Maria resolveu demiti-lo. Hoje, ao analisar alguns registros do desempenho de Pedro, Maria notou que, apesar de seus constantes atrasos, ele era um funcionário excelente. Ao se deparar com essas novas evidências, Maria reconsidera sua constatação inicial.

b. O Pedro devia morar muito longe da empresa.

Deve ser o caso que o Pedro morava muito longe de empresa.

(147) a. Contexto: Um aluno precisa da assinatura de um professor de seu departamento. Sabendo que o professor normalmente trabalha até as cinco da tarde, $\mathrm{o}$ aluno passa em seu gabinete às $4 \mathrm{~h} 00$, mas o encontra vazio. No dia seguinte, o aluno decide verificar com a secretaria do departamento por que o professor não estava na sala às $4 \mathrm{~h} 00$ :

b. O professor já devia ter ido pra casa quando você passou no escritório dele.

\footnotetext{
${ }^{14}$ Esse parece ser o caso, por exemplo, nos auxiliares modais do inglês, como may-might, e can-could, como propõem Rullmann e Matthewson (2018).
} 
Deve ser o caso que o professor já tinha ido pra casa quando você passou no escritório dele.

As paráfrases das duas sentenças acima mostram que elas envolvem dedução com base no conhecimento presente sobre um fato que ocorreu em um intervalo de tempo passado. Note que sentenças como essa só recebem uma interpretação epistêmica quando o predicado sob o escopo do modal é estativo ou habitual. Caso o predicado seja eventivo, a sentença só se torna aceitável com a forma perifrástca do pretérito imperfectivo. Compare os exemplos abaixo:

(148) a. O Pedro devia estudar muito durante a faculdade.

habitual - $\checkmark$ epis

b. O Pedro devia ser muito bom de matemática.

estativo $-\checkmark$ epis

c. O Pedro devia sair de casa.

eventivo - *epis

d. O Pedro devia estar saindo de casa.

eventivo $-\checkmark$ epis

Curiosamente, esse é o mesmo padrão notado quando o pretérito imperfectivo (Pretérito Imperfeito) é utilizado em sentenças não-modais. Novamente, com predicados eventivos, apenas a forma perifrástica do pretérito imperfectivo é aceita:

(149) a. Quando eu conheci o João, ele estudava muito.

habitual - $\checkmark$ epis

b. Quando eu conheci o João, ele era bom de matemática.

estativo $-\checkmark$ epis

c. Quando eu conheci o João, ele saía de casa.

eventivo - *epis

d. Quando eu conheci o João, ele estava saindo de casa.

eventivo $-\checkmark$ epis

A conclusão a que chegamos é de que o prejacente de sentenças como (146b) é interpretado como uma oração no pretérito imperfectivo. De acordo com os pressupostos sobre tempo e aspecto adotados para esta dissertação, o pretérito imperfectivo envolve um núcleo temporal pretérito combinado com um núcleo aspectual imperfectivo. Logo, o modal em sentenças como (146b) é interpretado acima do escopo do núcleo temporal.

Uma última evidência são as sentenças em que o modal com morfologia de pretérito imperfectivo tem escopo sob uma oração encabeçada pelo auxiliar perfeito ter, como (147b). Como propusemos no capítulo 2, o modal em sentenças como essas tem perspectiva presente e um prejacente cuja interpretação temporal é equivalente à do pretérito perfeito. O pretérito perfeito (Pretérito Mais-que-perfeito) é formado pela combinação de um núcleo temporal pretérito, que denota um intervalo de tempo contextualmente saliente, e o aspecto perfeito, que situa o tempo de uma eventualidade em um momento anterior a esse intervalo. Parece que realmente não somos capazes de explicar a interpretação desses exemplos sem recorrer a um tempo referencial alojado no prejacente dos 
modais epistêmicos. Antes de concluirmos esta seção, uma palavra sobre as implicações sintáticas dessa conclusão.

\subsection{Discrepância morfossemântica}

A conclusão da última subseção foi de que existe uma discrepância morfossemântica na interpretação dos modais epistêmicos: a morfologia tempo-aspectual realizada no modal é interpretada sob o escopo dele.

Stowell (2004) lista três abordagens para lidar com esse mismatch. A primeira alternativa seria assumirmos posições-base idênticas para modais epistêmicos e raiz. Nesse caso, os modais se moveriam para uma projeção funcional para checar traços. O tipo de projeção funcional para a qual o modal se move determinaria sua interpretação. Para os modais epistêmicos, essa abordagem é problemática, pois ela pressupõe um movimento através do núcleo temporal, em violação do Head Movement Constraint de Travis (1984) ${ }^{15}$.

Para contornarmos esse impedimento, poderíamos assumir que o modal se moveria através do núcleo temporal por virtude de um movimento XP, em vez de um movimento de núcleo. Essa segunda alternativa, mais complexa, envolveria uma derivação em que o VP complemento do modal seria extraído de sua categoria oracional previamente. Stowell (2004), no entanto, desconhece qualquer evidência empírica independente que justifique essa abordagem.

A alternativa mais promissora, e aquela que adotamos para esse trabalho, parece ser assumirmos que modais epistêmicos e modais raiz são gerados em posições-base distintas. Nesse caso, modais raiz seriam movidos para o núcleo do TP, onde se combinariam com o afixo de pretérito. Modais epistêmicos seriam gerados acima do TP, e o núcleo temporal seria alçado para a posição de núcleo de ModP, onde se combinaria com o modal.

$$
\begin{aligned}
& \text { a. }\left[\mathrm{TP} \mathrm{T}+\operatorname{Mod}_{i}^{\mathrm{RAIZ}}\left[\operatorname{ModP} t_{i}[\mathrm{VP} \ldots \mathrm{V} \ldots]\right]\right] \\
& \text { b. }\left[\operatorname{ModP} \operatorname{Mod}^{\mathrm{EPIS}}+\mathrm{T}_{i}\left[\mathrm{TP} t_{i}[\mathrm{VP} \ldots \mathrm{V} \ldots]\right]\right]
\end{aligned}
$$

O núcleo temporal movido abertamente seria interpretado em sua posição de concatenação, configurando um caso análogo à reconstrução.

\footnotetext{
${ }^{15}$ Uma discussão mais aprofundada sobre aspectos sintáticos da interação entre modalidade e tempo está fora do escopo dessa dissertação. Para um tratamento sintático desse tema seguindo os pressupostos teóricos da gramática gerativa, cf. Zagona (2007, 2008), além, é claro, de Stowell (2004).
} 


\subsection{Conclusão e questões em aberto}

Vamos recapitular o que foi discutido neste capítulo. Começamos o capítulo com um resumo dos dados relevantes e um levantamento de parte da bibliografia sobre o tema. Embora a questão de como modais fixam sua perspectiva temporal ainda seja alvo de debates, a posição assumida pela maior parte dos pesquisadores é de que existe uma diferença de altura entre modais epistêmicos e raiz. Essa conclusão é corroborada pela generalização de que modais epistêmicos sempre têm perspectiva presente em orações matriz. Os dados do PB trazem uma evidência adicional de que modais epistêmicos realmente são interpretados acima do núcleo temporal, visto que, nessa língua, a morfologia tempo-aspectual afixada ao modal epistêmico é interpretada sob seu escopo. Sendo assim, essa é a análise que acreditamos acomodar melhor nossos dados.

Essa proposta encontra pelo menos dois contra-argumentos. O primeiro deles é a existência de sentenças em que modais epistêmicos aparentam ter perspectiva passada. Como mostramos, essas sentenças dependem de contextos extremamente restritos, o que nos levou a questionar a validade dessas construções enquanto contraexemplos à generalização anterior. A visão que adotamos é que exemplos em que o modal epistêmico aparenta ter perspectiva passada são, na verdade, casos de sequência de tempos, nos quais a morfologia tempo-aspectual do modal concorda com a morfologia do verbo de uma oração matriz elidida. Isso significa reduzir dois problemas a um, visto que o comportamento de modais epistêmicos em contextos intensionais já representa, em si só, um segundo desafio à proposta de esses modais teriam escopo sobre o tempo. Esta é a primeira questão que esse capítulo deixa em aberto: Kratzer (1998) defende que verbos sujeitos à sequência de tempos estariam sob o escopo de um tempo-zero que espelharia a morfologia tempo-aspectual do verbo da oração matriz. Por outro lado, a evidência de que modais epistêmicos estariam sempre acima do escopo do tempo é bastante convincente. Como explicar, então, o fenômeno de sequência de tempos com modais epistêmicos? Nos parece mais simples encontrar uma maneira de contornar esse obstáculo do que explicar o comportamento temporal dos modais sem lançar mão de alturas de interpretação distintas.

Uma segunda questão que permanece aberta é uma aparente restrição à combinação entre modais epistêmicos e o aspecto perfectivo. Como observamos no capítulo 2, a morfologia perfectiva bloqueia uma leitura epistêmica no PB. Apenas a sentença (152b), com uma leitura deôntica, é considerada uma paráfrase aceitável para o exemplo (152).

(152) O João pôde fazer a prova em uma data alternativa.

a.\#Pode ser que o João tenha feito a prova em uma data alternativa.

b. Foi permitido que o João fizesse a prova em uma data alternativa.

Não é desejável atribuir esse comportamento à natureza da modalidade epistêmica, 
visto que ele não é atestado em todas as línguas cujos modais são flexionados. Laca (2018a), por exemplo, traz um caso do espanhol em que a morfologia de pretérito perfectivo permite três leituras distintas, entre elas uma leitura epistêmica:

(153) El ladrón pudo entrar por la ventana.

o ladrão pôde entrar por a janela

'O ladrão pôde entrar pela janela.' [Laca (2018a), exemplo (1)]

(154) a. Leitura epistêmica: É possível que o ladrão tenha entrado pela janela.

b. Leitura raiz: O ladrão pôde entrar pela janela.

c. Leitura contrafactual: O ladrão poderia ter entrado pela janela, mas ele não entrou.

Hacquard (2006) traz exemplos do francês em que o modal com morfologia de pretérito perfectivo é interpretado epistemicamente, como em (155), mas aponta que essa leitura não está disponível no italiano, como se vê no exemplo (156).

Bingley a pu parler à Jane.

bingley tem podido falar com jane

'Foi possível que Bingley falasse com a Jane.'

(156)\# Bingley ha potuto parlare a Jane.

bingley tem podido falar com jane

'Foi possível que Bingley falasse com a Jane.'

A autora indaga se essa restrição estaria relacionada à maneira como as línguas fazem o spell-out das duas ordens relativas de modal-tempo-aspecto, mostradas em (151). Seguindo essa linha de raciocínio, assumiríamos que, no francês, a unidade morfologicamente complexa da sentença (155) seria o spell-out tanto de TEMPO + ASPECTO + MODAL quanto de MODAL + TEMPO + ASPECTO. Italiano, por outro lado, não permitiria que essas duas formas tivessem o mesmo spell-out, e verbos com morfologia perfectiva, como (ha) potuto seriam apenas o spell-out de TEMPO+ASPECTO+MODAL.

Uma análise aos moldes dessa não parece funcionar para o PB. Como discutimos extensivamente ao longo dessa dissertação, formas como devia e podia, com morfologia imperfectiva, são ambíguas entre as duas ordens de escopo. Essa restrição realmente parece estar limitada aos modais com morfologia perfectiva, mas uma explicação sobre ela ficará para estudos futuros. 


\section{Capítulo 4}

\section{Orientação Temporal}

Esse capítulo será dedicado a uma investigação sobre o comportamento temporal do prejacente de sentenças modais. A discussão será dividida em duas partes: Na primeira parte do capítulo, examinaremos a composição morfológica dos prejacentes. Em outras palavras, buscaremos mapear os morfemas que entram para o cálculo de cada tipo de orientação temporal atestada no PB. Na segunda parte, investigaremos a correlação entre interpretação modal e orientação temporal. Existe alguma restrição à orientação temporal de modais raiz ou epistêmicos? Se existe, como explicá-la?

Iniciaremos esse capítulo com uma revisão dos dados do PB (seção 4.1). Em seguida, discutiremos a origem da orientação futura, que é aparentemente desmotivada em várias línguas já estudadas (seção 4.2). Combinando as conclusões obtidas neste capítulo e no último, a seção 4.3 traz uma análise composicional da interação entre modalidade e tempo no PB. A penúltima seção, 4.4, aborda a questão das restrições à orientação temporal de sentenças modais. Os resultados são resumidos na seção 4.5.

\subsection{Revisão de dados}

Como vimos no capítulo 2, as configurações morfossintáticas que originam cada orientação temporal são superficialmente idênticas entre modais raiz e modais epistêmicos, com a exceção das orientações verdadeiramente passadas, que só emergem no complemento de modais epistêmicos. Isso não é surpreendente, visto que apenas modais epistêmicos têm um núcleo temporal sob seu escopo.

Vamos começar olhando para sentenças com orientação perfeita, como (157a) e (157b). Essa orientação é bastante transparente, e surge sempre que o predicado sob o escopo do modal é encabeçado pelo auxiliar perfeito ter. Como o aspecto perfeito desempenha o papel de deslocar o tempo de uma eventualidade para um momento anterior a um certo intervalo, não há nada digno de nota nessas sentenças. 
(157) a. O Eduardo deve ter ido mal na prova.

b. Os alunos têm que ter cursado Introdução à Linguística.

Uma orientação presente só é possível quando o prejacente do modal contém um predicado estativo (em (158a)) ou habitual (em (158b)). Não há qualquer elemento morfologicamente realizado que pareça influenciar a orientação temporal de sentenças como estas.

(158) a. O João teve que morar no campus.

b. O João deve viajar bastante.

A orientação futura, ilustrada pelos exemplos (159a) e (159b), também não depende de nenhum elemento abertamente realizado, e emerge sempre que o predicado sob o escopo do modal é eventivo. Ela parece ser a interpretação default do prejacente de sentenças modais, e merece uma seção dedicada a ela.

a. Deve chover mais tarde.

b. Os professores têm que corrigir as provas rapidamente.

Os grupos de exemplos acima são compostos por sentenças com interpretação epistêmica e sentenças com interpretação raiz. Embora estejamos assumindo que a orientação temporal de cada par de sentenças é semanticamente idêntica, como concluímos no capítulo anterior, modais epistêmicos tomam escopo sobre o tempo. Logo, podemos assumir que os exemplos epistêmicos com orientação presente (158b), perfeita (157a) e futura (159a) têm prejacentes morfologicamente mais complexos que suas contrapartes com interpretação raiz. Esses exemplos envolveriam um núcleo temporal presente, sem efeitos semânticos sobre sua orientação temporal. Sentenças com modais epistêmicos em que o núcleo temporal é pretérito, por outro lado, dão origem a leituras que estão indisponíveis para modais raiz.

A primeira dessas orientações temporais exclusivas aos modais epistêmicos é uma orientação verdadeiramente passada, que emerge quando o prejacente de um modal é composto por um núcleo temporal pretérito. Se esse prejacente também contém um núcleo aspectual perfeito, a leitura obtida será de Pretérito mais-que-perfeito. Essas duas possibilidades são ilustradas em (160):

(160) a. O Pedro devia estar preso no escritório.

b. Ele devia ter saído para uma reunião.

Lembre-se que, para esse trabalho, estamos assumindo quatro núcleos temporais: imperfectivo, perfectivo, perfeito, e prospectivo. As duas sentenças acima correspondem às 
combinações de um núcleo temporal pretérito com os aspectos imperfectivo e perfeito. No capítulo anterior, vimos que modais epistêmicos no PB e no italiano não se combinam com o aspecto perfectivo. E o aspecto prospectivo? Se nossa análise está no caminho certo, esperaríamos uma sentença em que o modal recebesse morfologia de Futuro do Pretérito e se referisse à possibilidade de algo vir a acontecer no passado. A sentença (162a) seria uma candidata a tal interpretação:

(161) Contexto: Ontem, José, que sempre se veste de maneira casual, chegou para o trabalho trajando roupas estranhamente formais. Hoje, dois colegas dele comentam sobre a mudança inesperada de comportamento, e um deles conclui:

(162) a. ?Ele poderia / deveria ter uma reunião com o chefe mais tarde.

b. Talvez ele fosse ter uma reunião com o chefe mais tarde.

O julgamento é bastante sutil, e não temos certeza se a interpretação pretendida realmente está disponível para a sentença (162a). Se estiver, (162b) é uma paráfrase adequada para essa sentença. Se (162a) for infeliz no contexto descrito, isso não necessariamente traz um problema para nossa análise. O ponto crucial para nós é que existe um núcleo temporal no prejacente dos modais epistêmicos, e a evidência trazida pelas outras sentenças com orientação passada nos parece convincente o bastante.

Até esse ponto, nós identificamos três tipos de orientação temporal comuns a todos os modais, e outros três tipos restritos aos modais epistêmicos. A origem das orientações perfeitas e passadas de um modo geral, é bastante clara: interpretações como essas surgem quando há um auxiliar perfeito e/ou um núcleo temporal pretérito abaixo do escopo do modal. Essas observações, resumidas no quadro 4.1, sugerem fortemente que modais não seriam capazes de manipular a interpretação temporal de seus prejacentes.

\begin{tabular}{lll}
\hline orientação & epistêmicos & raiz \\
\hline perfeita & PRES +PERF & PERF \\
passada & PRET + IMP & $\#$ \\
Pretérito mais-que-perfeito & PRET $+\mathrm{IMP}+\mathrm{PERF}$ & $\#$ \\
Futuro do Pretérito & PRET $+\mathrm{IMP}+\mathrm{PROSP}$ & $\#$ \\
\hline
\end{tabular}

Quadro 4.1: Fontes da orientação temporal em sentenças modais (a revisar)

Mas e as orientações presentes e futuras? Como vimos nos exemplos dessa seção, essas leituras parecem estar em co-variação: uma orientação futura emerge quando há um predicado eventivo sob o escopo do modal; uma orientação presente emerge quando há um 
predicado estativo ou habitual. Isso nos leva a indagar se existiria algum elemento coberto sob o escopo dos modais que seria responsável por deslocar para o futuro a interpretação de seus prejacentes. Exploraremos essa possibilidade na seção seguinte.

\subsection{A origem da orientação futura}

Diversos trabalhos já procuraram explicar a emergência da orientação futura em contextos modais. As estratégias que estudiosos têm adotado para lidar com o fenômeno podem ser divididas em três grupos: $(i)$ codificar a orientação futura na entrada lexical dos modais (Condoravdi (2002)); (ii) assumir a presença de um operador futuro coberto (Matthewson (2012)), Wurmbrand (2014)); (iii) postular princípios interpretativos responsáveis pela emergência de cada orientação temporal (Werner (2006)). Na primeira parte dessa seção, discutiremos algumas dessas propostas, começando por Condoravdi (2002).

\subsubsection{Estudos anteriores}

\section{Condoravdi (2002)}

A autora propõe que verbos modais seriam, também, operadores temporais, capazes de deslocar a interpretação de seus prejacentes para o futuro. Condoravdi (2002) codifica a orientação futura na entrada lexical dos modais do inglês através da adição do intervalo $[i, \ldots)$, que se inicia em $i$ e se estende indeterminadamente. Um modal existencial, como might teria a entrada lexical em (163).

$$
\llbracket \operatorname{might}_{\mathcal{F}, \mathcal{G}} \rrbracket=\lambda P . \lambda w \cdot \lambda i \cdot \exists w^{\prime}\left[w^{\prime} \in \operatorname{Best}_{\mathcal{G}(w, i)}(\cap \mathcal{F}(w, i)) \& A T\left(\left[i,{ }_{-}\right), w, P\right)\right]
$$

A natureza da relação $A T$ depende da natureza de seu terceiro argumento:

$$
A T(i, w, P)= \begin{cases}\exists e[P(w)(e) \& \tau(e, w) \subseteq t] & \text { se } P \text { é eventivo } \\ \exists e[P(w)(e) \& \tau(e, w) \circ t] & \text { se } P \text { é estativo } \\ P(w)(t) & \text { se } P \text { é temporal }\end{cases}
$$

Informalmente, $A T$ define que para uma certa eventualidade $e$ ocorrer $e m$ um certo intervalo de tempo $i$, e deve estar completamente contida em $i$, caso seja um evento, ou apenas se sobrepor a $i$ caso seja um estado. Se o terceiro argumento for uma propriedade de tempos, $A T$ simplesmente aplica seu argumento temporal $\left[i,_{-}\right)$àquela propriedade.

A inclusão da relação $A T$ e do intervalo $\left[i,{ }_{-}\right)$à entrada lexical dos modais garante a Condoravdi (2002) a flexibilidade necessária para explicar o comportamento temporal distinto de predicados eventivos e estativos, mas o argumento da autora para incluí-los não é particularmente forte. A motivação de Condoravdi (2002) foi principalmente teórica - 
uma vez que ela assumiu que modais não-raiz não teriam tempo sob seu escopo, a presença de um tempo futuro deixa de ser uma opção. O primeiro problema com esse argumento é a evidência bastante forte de que de fato há um núcleo temporal sob o escopo dos modais epistêmicos. Como discutimos nos capítulos anteriores, os dados do PB corroboram essa observação. O segundo problema é que o argumento de Condoravdi (2002) parte do pressuposto de que o futuro é um núcleo temporal. Se adotarmos a visão de que esse elemento de futuridade é um operador aspectual (como fez Matthewson (2012, 2013)) ou um operador modal (como fez Wurmbrand (2014) para verbos de atitude proposicional), essa motivação deixa de existir, mesmo em uma teoria que proponha que não há tempo no escopo de modais.

Klecha (2016) apresenta ainda um argumento empírico contra a proposta de Condoravdi (2002). O autor se baseia em sentenças como $(166)^{1}$ para propor a presença de um operador futuro externo ao modal. Exemplos como esse são um problema para a semântica proposta por Condoravdi (2002), que só é capaz de lidar com casos em que a orientação temporal é de presente perfeito, mas não com casos em que a interpretação temporal do prejacente é deslocada para o futuro, e então para o passado.

(165) He may have won.

ele pode ter vencido

(166) Não reserve suas passagens para Cuba para o próximo verão ainda...

The government might have re-established the embargo (by then).

O governo pode ter reestabelecido o embargo (até lá).

Vejamos como a semântica de Condoravdi (2002) lida com exemplos como (166):

(167) a. O governo pode ter reestabelecido o embargo.

b. [TP PRES [ModP pode [AspP PERF [VP o governo reestabelecer o embargo ]]]]

1. $\llbracket \mathrm{PRES} \rrbracket=\lambda P . \lambda w[A T($ agora $, w, P)]$

2. $\llbracket \mathrm{PERF} \rrbracket=\lambda P \cdot \lambda w \cdot \lambda i \cdot \exists i^{\prime}\left[i^{\prime}<i \& A T\left(i^{\prime}, w, P\right)\right]$

3. $\llbracket$ pode $\rrbracket=\lambda P \cdot \lambda w \cdot \lambda i \cdot \exists w^{\prime}\left[w^{\prime} \in \operatorname{Best}_{\mathcal{G}(w, i)}(\cap \mathcal{F}(w, i)) \& A T\left(\left[i,{ }_{-}\right), w, P\right)\right]$

4. $\llbracket[$ o governo reestabelecer o embargo $] \rrbracket=\lambda w \cdot \lambda e[$ o governo reestabelece o embargo $]$ $(w)(e)$

5. $\llbracket \mathrm{AspP} \rrbracket=\llbracket \mathrm{PERF} \rrbracket(\llbracket[$ o governo reestabelecer o embargo $] \rrbracket)$

6. $\llbracket \operatorname{AspP} \rrbracket=\lambda w \cdot \lambda i \cdot \exists i^{\prime}\left[i^{\prime}<i \& \exists e[P(w)(e) \& \tau(e, w) \subseteq i]\right]$

7. $\llbracket \operatorname{ModP} \rrbracket=\llbracket \operatorname{pode} \rrbracket(\llbracket \mathrm{AspP} \rrbracket)$

\footnotetext{
${ }^{1}$ Exemplo (69) em Klecha (2016).
} 
8. $\llbracket \operatorname{ModP} \rrbracket=\lambda w \cdot \exists w^{\prime}\left[w^{\prime} \in \operatorname{Best}_{\mathcal{G}(w, i)}(\cap \mathcal{F}(w, i)) \& \exists i^{\prime}\left[i^{\prime}<\left[i,{ }_{-}\right) \&\right.\right.$ $\exists e[$ o governo reestabelecer o embargo $\left.\left.]\left(w^{\prime}\right)(e) \& \tau\left(e, w^{\prime}\right) \subseteq i^{\prime}\right]\right]$

9. $\llbracket \mathrm{TP} \rrbracket=\llbracket \mathrm{PRES} \rrbracket(\llbracket \operatorname{ModP} \rrbracket)$

10. $\llbracket \mathrm{TP} \rrbracket=\lambda w \cdot \exists w^{\prime}\left[w^{\prime} \in \operatorname{Best}_{\mathcal{G}(w, i)}(\cap \mathcal{F}(w, i)) \& \exists i^{\prime}\left[i^{\prime}<\right.\right.$ agora,_ $) \&$ $\exists e \quad[$ o governo reestabelecer o embargo $\left.\left.]\left(w^{\prime}\right)(e) \& \tau\left(e, w^{\prime}\right) \subseteq i^{\prime}\right]\right]$

O sintagma AspP é encabeçado pelo aspecto perfeito, o que significa que ele é uma propriedade de tempos. Como vemos nos cálculos acima, quando aplicamos esse argumento ao modal, a relação $A T$ do modal simplesmente repassa seu argumento temporal ao sintagma AspP. Como resultado, a semântica do PERF tem efeito sobre todo o intervalo $[i, \ldots)$. Isso significa que a sentença (166), de acordo com a semântica de Condoravdi (2002) seria julgada verdadeira se e somente se o governo tiver reestabelecido o embargo em um intervalo de tempo anterior ao momento de fala. Essas não são as condições de verdade que queremos para (166) no contexto descrito.

\section{Matthewson (2012)}

Existem ainda evidências morfológicas para a presença de um operador futuro extrínseco aos modais. Matthewson $(2012,2013)$ traz dados particularmente reveladores da língua Gitksan $^{2}$. Nessa língua, a presença do marcador dim é necessária e suficiente quando o tempo de uma eventualidade é situado em um momento posterior ao tempo de referência, como é mostram os exemplos $(168)^{3}$ :

$$
\begin{aligned}
& \text { a. } \quad \text { *(dim) limx }=t \quad \text { James taahlakw. } \\
& *(\text { FUT }) \text { cantar=DM James amanhã. } \\
& \text { 'O James cantará amanhã.' } \\
& \text { b. } \quad \text { *(dim) siipxw=t James t'aahlakw. } \\
& \text { *(FUT) doente=DM James amanhã. } \\
& \text { 'O James estará doente amanhã.' }
\end{aligned}
$$

A mesma marcação está presente em sentenças com orientação futura, como $(169)^{4}$, no qual o modal circunstancial da'akhlxw tem perspectiva temporal presente, e em sentenças com perspectiva futura, como $(170)^{5}$ :

\footnotetext{
${ }^{2}$ Língua tsimshiânica falada no noroeste da Colúmbia Britânica por cerca de 200 falantes.

${ }^{3}$ Exemplo (8) em Matthewson (2012).

${ }^{4}$ Exemplo (18) em Matthewson (2012).

${ }^{5}$ Contexto: Ele não é capaz de cozinhar agora, mas será capaz depois de fazer um curso de culinária. Exemplo (19) em Matthewson (2012).
} 
(169) da'akxw/-i]-'y dim ayee=hl bax-'y.

poder $\quad$ FUT rápido correr

'Eu consigo correr rápido.'

(170) dim daakxw-i-t dim jam-t

FUT poder $\quad$ FUT cozinhar.3SG

'Ele conseguirá cozinhar.'

Com base nesses dados, Matthewson (2012) propõe que modais não são inerentemente capazes de deslocar a interpretação temporal de seus prejacentes para o futuro. Sendo assim, a entrada lexical de um modal como da'akhlxw não precisaria da adição do intervalo $\left[i,_{-}\right)$. De fato, a relação $A T$ tampouco seria necessária, afinal, o aktionsart do predicado encaixado no modal não influencia a orientação temporal em Gitksan: tanto predicados estativos quanto eventivos dependem da presença do marcador dim para que a orientação temporal das sentenças seja futura. Isso vai de encontro ao que foi constatado por Condoravdi (2002) no inglês e por nós no PB $^{6}$. Matthewson (2012) adota a seguinte entrada lexical para o modal $d a^{\prime} a \mathrm{k} h l x w^{7}$ :

$$
\llbracket d a^{\prime} a \mathrm{k} h l x w_{\mathcal{F}} \rrbracket= \begin{cases}\lambda P . \lambda i \cdot \exists w^{\prime}\left[w^{\prime} \in \cap \mathcal{F}(w, i) \& P(i)\left(w^{\prime}\right)=1\right] & \text { se } \mathcal{F} \text { é circunstancial } \\ \text { Indefinido } & \text { em outros casos }\end{cases}
$$

Quanto à natureza do morfema dim, Matthewson (2012) assume se tratar de um marcador do aspecto prospectivo, que, como estamos assumindo para essa dissertação, é a imagem espelhada do aspecto perfeito:

$$
\llbracket d i m \rrbracket=\lambda P \cdot \lambda i \cdot \exists i^{\prime}: i^{\prime}>i \& P\left(i^{\prime}\right)
$$

Antes de discutirmos os dados do PB, apresentaremos a teoria de Werner (2006), que propõe que a orientação temporal de modais estaria sujeita a princípios pragmáticos.

\section{Werner $(2003,2006)$}

A motivação principal de Werner $(2003,2006)$ foi a aparente correlação entre orientação temporal e interpretação modal em sentenças como (173) e $(174)^{8}$ :

\footnotetext{
${ }^{6}$ Voltaremos a esse ponto no final da seção.

${ }^{7} \mathrm{~A}$ autora constrói essa entrada lexical como uma pressuposição pois esse modal só se combina com bases modais circunstanciais.

${ }^{8}$ Exemplos (4) e (5) em Werner (2006).
} 
(173) Janet must live in student housing.

janete tem que morar em aluno alojamento

'A Janete tem que morar no alojamento estudantil.'

(174) John can't be our representative.

joão não pode ser nosso representante

'O João não pode ser nosso representante.'

Os dois exemplos acima podem ser interpretados de duas maneiras. A sentença (173) poderia ser interpretada como uma dedução sobre onde a Janete mora no presente ou como uma obrigação com efeito futuro. A sentença (174) poderia ser dita por um falante para expressar incredulidade sobre João ser nosso representante atualmente, ou uma proibição à sua candidatura futura. A generalização que emerge desses exemplos é: Quando os verbos modais nesses exemplos recebem uma interpretação epistêmica, a orientação temporal de seus prejacentes é obrigatoriamente presente. Quando os verbos modais recebem uma interpretação raiz, a orientação temporal é futura:

\begin{tabular}{l|ccc} 
& Passada & Presente & Futura \\
\hline Epistêmica & $\checkmark$ & $\checkmark$ & $\#$ \\
Circunstancial & $\#$ & $\#$ & $\checkmark$
\end{tabular}

Quadro 4.2: Co-variação entre base modal e orientação temporal (Werner (2003, 2006)).

Werner $(2003,2006)$ sugere uma análise baseada em pragmática para esse fenômeno. Grosso modo, o autor atribui o comportamento temporal de sentenças modais à própria natureza mais fraca de uma asserção modal e à assimetria entre presente, passado e futuro. Um fato bastante conhecido sobre asserções modais, como $(175)^{9}$, é que elas são consideradas infelizes caso o falante que as proferiu saiba o valor de verdade da proposição encaixada sob o modal. Em outras palavras, uma sentença como (175) não seria dita se o falante soubesse se João está dormindo ou não.

João tem que estar dormindo.

O autor captura essa restrição através do Princípio da Disparidade, um princípio pragmático que determina que haja mundos na base modal de um verbo em que seu prejacente seja verdadeiro, e mundos em que ele não seja. Formalmente, temos:

\footnotetext{
${ }^{9}$ Tradução do exemplo (8) em Werner (2006).
} 
(176) Princípio da Disparidade:

Werner (2006, pp. 6)

$\cap \mathcal{F}(w) \cap \llbracket[\lambda w \text {. João está dormindo em } w]_{\mathcal{F}} \rrbracket \neq \cap \mathcal{F}(w)$

$\cap \mathcal{F}(w) \cap \llbracket[\lambda w \text {. João está dormindo em } w]_{\mathcal{F}} \rrbracket \neq \varnothing$

Werner $(2003,2006)$ adota uma ontologia baseada em mundos ramificados (Thomason (1984)), o que implica uma assimetria entre o passado e o futuro. O passado seria constituído por um único ramo, que se dividiria a todo momento em direção ao futuro. Este, por sua vez, teria ramificações múltiplas ${ }^{10}$. Nesse modelo, mundos possíveis podem ser entendidos como histórias ${ }^{11}$, ou seja, como percursos lineares até uma raiz. Com base nessas definições, o autor propõe que a base modal de modais raiz seria constituída por uma única estrutura ramificada, dividida a partir do momento de fala. A base modal dos modais epistêmicos, por sua vez, seria constituída por um conjunto dessas estruturas. Essa análise é ilustrada pela figura 4.1, de Portner (2009) (figura 5.2 no original):

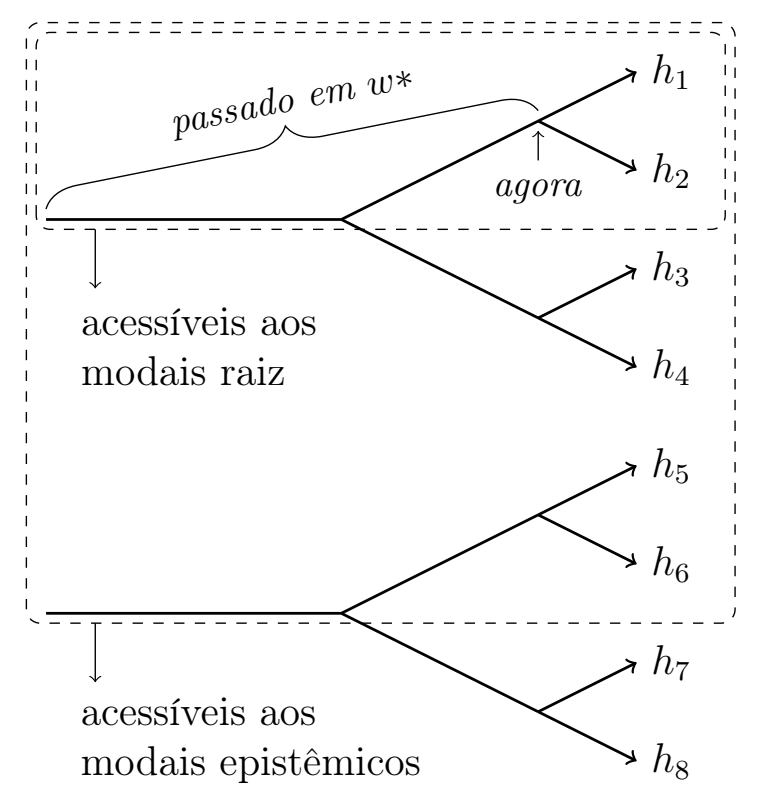

Figura 4.1: Bases modais de acordo com Werner (2003, 2006)

Como a base modal de modais raiz é constituída por um único ramo, o valor de verdade de qualquer proposição $\phi$ será o mesmo em todos os mundos $w$ que compõem essa base modal. Para que esses modais não violem o Princípio da Disparidade, eles são obrigados a quantificar sobre histórias que se ramificam a partir do momento de fala. Isso explica a orientação supostamente sempre futura dos modais raiz.

Modais epistêmicos, por outro lado, dispõem de uma série de estruturas ramificadas como seu domínio de quantificação. Isso permite que essa classe de modais quantifique sobre histórias presentes ou passadas sem violação do Princípio da Disparidade. No

\footnotetext{
${ }^{10} C f$. Portner (2009, p. 233) e as referências lá contidas para explicações mais detalhadas do modelo de mundos ramificados.

${ }^{11} \mathrm{Ou}$ cursos históricos, como em Banerjee (2018).
} 
entanto, isso também possibilitaria uma orientação futura para esses modais, o que, de acordo com Werner (2003, 2006), não ocorre.

Para explicar essa outra restrição, o autor introduz um segundo princípio interpretativo - o Princípio da Não-Disparidade:

(177) Princípio da Não-Disparidade:

Werner (2006, pp. 14)

Uma proposição não pode fazer distinções entre os mundos que se ramificam a partir do momento de fala.

O Princípio da Não-Disparidade exige que as distinções feitas para satisfazer o Princípio da Disparidade sejam apenas entre fatos já definidos. Isso impede que modais epistêmicos quantifiquem sobre histórias futuras, mas introduz um novo problema, afinal, modais raiz supostamente só teriam orientação futura. Para contornar essa questão, Werner (2006) sugere que o Princípio da Não-Disparidade possa ser violado, ao contrário do Princípio da Disparidade.

Em resumo, modais epistêmicos podem ter orientação passada ou presente sem violação do Princípio da Disparidade, mas uma orientação futura é bloqueada pelo Princípio da Não-Disparidade. Com os modais raiz, no entanto, ocorre um conflito entre os dois princípios. O Princípio da Disparidade exige que esses modais quantifiquem sobre histórias futuras a fim de garantir diversidade entre os mundos da base modal. Por outro lado, o Princípio da Não-Disparidade impede que distinções sejam feitas entre histórias futuras. Nesse caso, o Princípio da Disparidade vence e o Princípio da Não-Disparidade é violado.

Tendo discutido as abordagens disponíveis para explicar a orientação futura de verbos modais, estamos prontos para apresentar a contribuição do PB para a discussão.

\subsubsection{Orientações futuras no português brasileiro}

Como já mostramos, à primeira vista, a orientação futura no PB emerge mesmo quando não há nenhum elemento tempo-aspectual explicitamente presente no prejacente de um modal. Retomamos esse ponto com um exemplo de um modal epistêmico e um modal raiz orientados ao futuro:

(178) a. Deve chover hoje.

b. O João tem que entregar o relatório logo.

No entanto, as mesmas sentenças poderiam ser parafraseadas com a presença de um morfema de futuro ${ }^{12}$, sem que haja qualquer mudança em suas condições de verdade:

\footnotetext{
${ }^{12}$ Esse morfema já está praticamente em desuso na língua falada, mas ainda é amplamente utilizado na língua escrita, especialmente na composição do Futuro do Pretérito.
} 
(179) a. Deverá chover hoje.

b. O João terá que entregar o relatório logo.

Nesse ponto, poderíamos tomar dois caminhos de análise distintos: (i) assumir que a marcação de futuro nas sentenças em (179) é meramente expletiva, sem contribuição semântica, ou (ii) assumir que o morfema de futuro é obrigatório nas sentenças com orientação futura, mas pode ser realizado como um morfema zero.

Se assumirmos a primeira análise, esperaríamos que esse morfema também possa ocorrer em sentenças com orientação passada sem nenhuma influência semântica. Essa previsão não se confirma:

(180) a. Contexto: Maria é gerente da empresa em Pedro trabalhou ano passado. Na época, Pedro chegava atrasado com frequência. Duvidando de sua dedicação ao emprego, Maria resolveu demiti-lo. Hoje, ao analisar alguns registros do desempenho de Pedro, Maria notou que, apesar de seus constantes atrasos, ele era um funcionário excelente. Ao se deparar com essas novas evidências, Maria reconsidera sua constatação inicial.

b.\#O Pedro deveria morar muito longe da empresa.

(181) a. Contexto: Um aluno precisa da assinatura de um professor de seu departamento. Sabendo que o professor normalmente trabalha até as cinco da tarde, o aluno passa em seu gabinete às 4h00, mas o encontra vazio. No dia seguinte, o aluno decide verificar com a secretaria do departamento por que o professor não estava na sala às 4h00:

b.\#O professor já deveria ter ido pra casa quando você passou no escritório dele.

O contexto descrito para a sentença (180b) favorece uma leitura epistêmica, com orientação passada. Ao adicionarmos o morfema -r-, a leitura epistêmica parece ficar indisponível. A leitura mais saliente passa a ser uma leitura raiz, com perspectiva presente e orientação presente. Nesse caso, a marcação de futuro do pretérito no modal não tem uma leitura temporal, sua função é enfraquecer o modal. O mesmo ocorre com a sentença (181b).

Essa marcação também não co-ocorre com modais com orientação presente:

(182) A: Você sabe onde a Maria está?

B:\#Ela deverá estar em casa. 
Lembre-se que, além das sentenças orientadas ao futuro do presente, como (179), sentenças orientadas ao futuro do pretérito ${ }^{13}$ também licenciam a ocorrência opcional do morfema de futuro:

(183) O João dev(er)ia ter uma reunião com o chefe naquela tarde.

Os dados do PB sugerem que a orientação futura emerge de um morfema extrínseco ao modal. Quando realizado fonologicamente, esse marcador precisa ser alçado e adjungido ao modal, como propõe Ferreira (2018):

$$
\ldots\left[\text { MODP } \operatorname{modal}+\mathrm{FUT}_{i}\left[\text { FutP }_{i} \mathrm{VP}\right]\right]
$$

Discutiremos a natureza desse marcador mais a fundo em breve. Por ora, assumiremos se tratar do aspecto prospectivo, exatamente como Matthewson (2012) propôs para o marcador dim do Gitksan:

$$
\llbracket \mathrm{FUT} \rrbracket=\lambda P . \lambda i \cdot \exists i^{\prime}: i^{\prime}>i \& P\left(i^{\prime}\right)
$$

O PB, no entanto, apresenta uma complicação adicional em relação a Gitksan. No PB, o aktionsart parece influenciar a emergência da orientação futura. Orações infinitivais com predicados eventivos sempre têm orientação futura. Orações com predicados estativos e habituais, por outro lado, podem ter orientação futura, que emerge em três cenários:

\section{(186) Orientação futura com predicados estativos ou habituais}

a. a presença de um morfema de futuro realizado;

b. um contexto apropriado;

c. a presença de advérbios temporais de futuro.

Seria possível explicar esse comportamento sem lançarmos mão de qualquer estipulação além da presença do marcador de futuro? Uma primeira opção seria postularmos que, na verdade, o aspecto prospectivo não situa uma eventualidade em um momento posterior ao tempo de referência, mas sim em um momento concomitante ou posterior a ele. Essa proposta seria implementada através da substituição da relação $>$ por $\geq$ na entrada lexical do aspecto prospectivo. A impossibilidade de orientação presente com predicados eventivos, nesse caso, seria explicada através de diferenças semânticas entre esses dois tipos de predicado. O presente representa um intervalo de tempo muito pequeno, que não comportaria um evento. Essa seria a fonte da orientação obrigatoriamente futura com predicados eventivos.

\footnotetext{
${ }^{13}$ Vale lembrar que, como discutimos anteriormente, não temos certeza sobre a aceitabilidade desses exemplos.
} 
Se essa análise estivesse no caminho certo, esperaríamos que sentenças com marcação futura e predicados estativos pudessem ter também orientação presente. Essa previsão não se confirma: quando o modal recebe morfologia de futuro e tem escopo sobre um predicado estativo, a orientação é inequivocamente futura. Isso é ilustrado pelo exemplo (187):

(187) O estádio deverá estar lotado para o jogo entre o Brasil e os Estados Unidos.

O resultado dessa discussão é que em sentenças modais com predicados eventivos, a orientação temporal é obrigatoriamente futura. Em sentenças com predicados estativos, a orientação é, por default, presente. Nesses casos, três elementos são capazes de deslocar a interpretação temporal do prejacente para o futuro: a presença da marcação de aspecto prospectivo no modal, um contexto propício, ou a presença de um advérbio de tempo. O ponto crucial desses exemplos é que a marcação futura sempre desloca a orientação temporal para o futuro, o que invalida explicações baseadas apenas no aktionsart dos predicados encaixados. A diferença entre uma orientação presente e futura realmente parece estar na projeção ou não do aspecto prospectivo. A generalização parece ser que o núcleo aspectual prospectivo é projetado opcionalmente quando o predicado é estativo, e obrigatoriamente quando o predicado é eventivo.

Antes de concluirmos essa seção, gostaríamos de especular sobre a diferença entre modais com morfologia de pretérito imperfectivo e modais com morfologia de futuro do pretérito. Como mostram diversos exemplos dessa dissertação, a morfologia de aspecto prospectivo co-ocorre transparentemente com a morfologia de aspecto imperfectivo em orações com um núcleo temporal passado ${ }^{14}$. Essa co-ocorrência, somada à possibilidade de realização do prospectivo como morfema zero, gera a alternância entre as formas devia e deveria, podia e poderia, e tinha que e teria que. Isso significa que modais com morfologia de pretérito imperfectivo são, na verdade, ambíguos entre duas formas:

$$
\begin{array}{ll}
\text { a. } & \operatorname{dev} \varnothing \quad i a \\
& \operatorname{dev} \text { PROSP PRET+IMP } \\
\text { b. } & \operatorname{dev} i a \\
& \operatorname{dev} \text { PRET+IMP }
\end{array}
$$

Isso explicaria por que as formas devia e deveria são intercambiáveis em diversos contextos, como nas sentenças em (189).

(189) a. Eu dev(er)ia ter estudado mais para essa prova.

b. Os alunos da graduação dev(er)iam fazer atividades extracurriculares.

\footnotetext{
${ }^{14}$ Matthewson (2012) observa a mesma interação em Gitksan.
} 
O que os dois exemplos acima têm em comum é o fato de que em nenhum deles o pretérito imperfectivo faz seu trabalho estritamente temporal. Em (189a), a interpretação mais saliente parece ser contrafactual. Em (189b), a marcação tem o efeito de enfraquecer o modal, como já foi amplamente discutido nessa dissertação. Embora mais trabalho empírico seja necessário, nossa previsão é que o único caso em que as duas formas de fato não são semanticamente equivalentes é quando o pretérito imperfectivo é interpretado de maneira estritamente temporal, como quando um modal epistêmico têm orientação passada.

Finalmente, assumiremos que a orientação presente, obtida quando o predicado no prejacente do modal é habitual ou estativo, também envolve um operador imperfectivo ${ }^{15}$.

Com essas estipulações, temos tudo que precisamos para uma análise formal e composicional da interação entre verbos modais, tempo e aspecto no PB.

\subsection{Análise composicional}

Esta seção será dedicada à aplicação da proposta de Ferreira (2018) a alguns exemplos do PB. Começaremos essa análise composicional revisitando a tabela 4.1. Baseados na discussão conduzida nas últimas seções, podemos adicionar a composição da orientação futura e da orientação presente.

\begin{tabular}{lll}
\hline orientação & epistêmicos & raiz \\
\hline presente & PRES+IMP & IMP \\
perfeita & PRES+PERF & PERF \\
futura & PRES+PROSP & PROSP \\
passada & PRET $+\mathrm{IMP}$ & $\#$ \\
Pretérito mais-que-perfeito & PRET $+\mathrm{IMP}+\mathrm{PERF}$ & $\#$ \\
Futuro do Pretérito & PRET $+\mathrm{IMP}+\mathrm{PROSP}$ & $\#$ \\
\hline
\end{tabular}

Quadro 4.3: Fontes da orientação temporal em sentenças modais (revisada)

Recapitulando o que foi discutido no capítulo 3, assumimos que modais epistêmicos sempre fixam sua perspectiva temporal no momento de fala ${ }^{16}$, visto que não estão sob o escopo de nenhum núcleo temporal. Como consequência, tanto tempo quanto aspecto entram para o cálculo da orientação temporal desses modais. Modais raiz, por outro lado, estão sob o escopo de tempo e aspecto, o que faz com que essa classe de modais

\footnotetext{
${ }^{15}$ De acordo com Ferreira (2016), a presença do operador imperfectivo acima de um predicado estativo não têm efeitos semânticos, sendo equivalente a um predicado estativo diretamente sob o escopo do núcleo tempo.

${ }^{16} \mathrm{Ou}$ em outro índice temporal contextualmente saliente.
} 
possa ter um repertório de perspectivas temporais mais rico, em detrimento de orientações temporais mais limitadas.

Ainda no capítulo 3, apresentamos duas teorias que obtiveram sucesso em conciliar os pressupostos kratzerianos com a generalização sobre a altura distinta dos modais raiz e epistêmicos. A primeira teoria, de Hacquard (2006), propõe a relativização de modais a eventos, em vez de mundos possíveis. A segunda teoria, de Ferreira (2018), captura a diferença de altura através da postulação de modificadores presentes na sintaxe que são específicos a cada base modal. Levando em conta que, para essa dissertação, adotamos uma ontologia isenta de eventos, utilizaremos as ferramentas teóricas de Ferreira (2018) para as formalizações apresentadas no restante dessa seção.

\subsubsection{Modais raiz}

Como vimos anteriormente, o cálculo temporal de sentenças com modais raiz é bastante direto: a perspectiva temporal é determinada pelo núcleo temporal e aspectual que têm escopo sobre o modal; a orientação temporal é determinada pelos operadores aspectuais abaixo do modal. A organização desses morfemas e seus respectivos tipos semânticos são mostrados na árvore abaixo, que servirá de base para todas as derivações com modais raiz que faremos.

(190) Árvore para sentenças com modais raiz

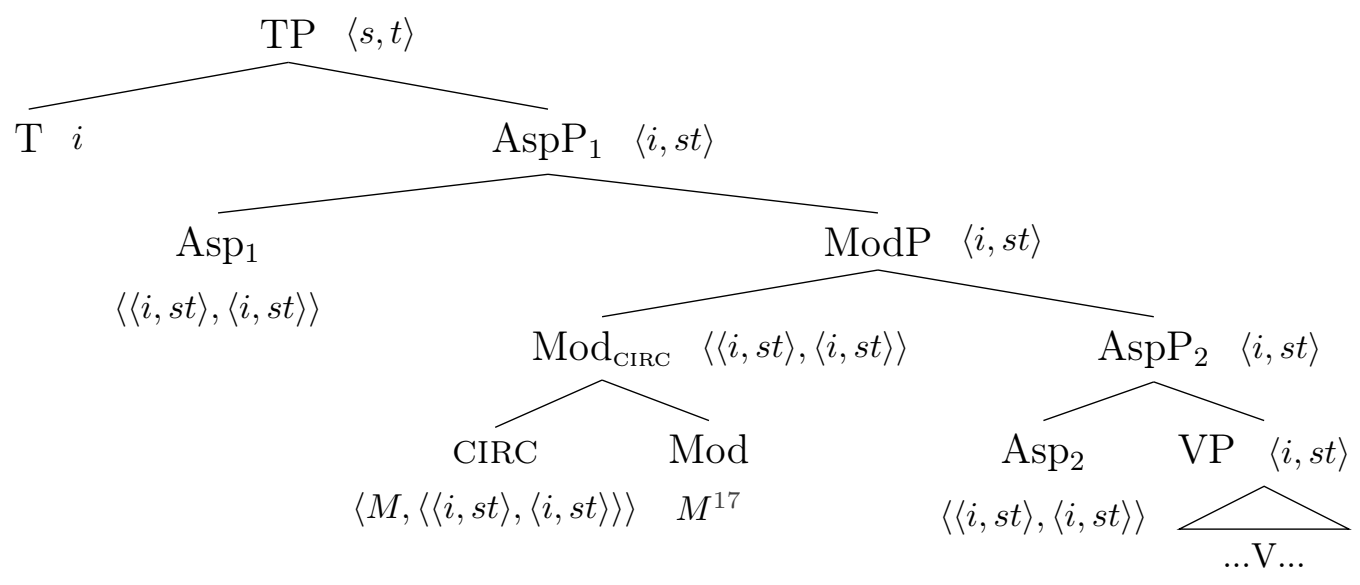

Começaremos calculando passo-a-passo as condições de verdade de uma sentença com perspectiva de pretérito perfectivo e orientação presente:

(191) O João teve que estar na reunião. ${ }^{18}$

\footnotetext{
${ }^{17}$ Sendo $M$ igual a $\langle\langle s,\langle i, s t\rangle\rangle,\langle\langle s, t\rangle,\langle i, s t\rangle\rangle\rangle$.

${ }^{18}$ Contexto: Uma mulher está reclamando com sua melhor amiga sobre o marido, que passou a festa de aniversário do filho inteira numa reunião de trabalho. Sua amiga a consola dizendo que o marido não teve outra opção além de estar na reunião.
} 
De acordo com os pressupostos teóricos adotados ao longo dessa dissertação, o léxico nos dá o seguinte:

1. $\llbracket \mathrm{VP} \rrbracket^{g}=\llbracket\left[\right.$ João está na reunião $\rrbracket^{g}=\lambda i . \lambda w$. João está na reunião em $i$ em $w$

2. $\llbracket \mathrm{Asp}_{2} \rrbracket^{g}=\llbracket \mathrm{IMP} \rrbracket^{g}=\lambda P . \lambda i \cdot \lambda w \cdot \exists i^{\prime \prime}\left[i \subseteq i^{\prime \prime} \& P\left(i^{\prime \prime}\right)(w)\right]$

3. $\llbracket \operatorname{Mod}_{\mathrm{CIRC}} \rrbracket^{g}=\lambda P \cdot \lambda i \cdot \lambda w \cdot \forall w^{\prime}\left[w^{\prime}\right.$ é compatível com as circunstâncias em $w$ em $i$ $\left.\longrightarrow P(i)\left(w^{\prime}\right)=1\right]$

4. $\llbracket \mathrm{Asp}_{1} \rrbracket^{g}=\llbracket \mathrm{PFV} \rrbracket^{g}=\lambda P . \lambda i \cdot \lambda w \cdot \exists i^{\prime}\left[i^{\prime} \supset i \& P\left(i^{\prime}\right)(w)\right]$

5. $\llbracket \mathrm{T} \rrbracket^{g}=\llbracket \mathrm{PRET} \rrbracket^{g}= \begin{cases}g(i) & \text { se } g(i)<\text { momento de fala } \\ \text { indefinido } & \text { nos demais casos }\end{cases}$

Os cálculos seguem por Aplicação Funcional:

1. $\llbracket \mathrm{AspP}_{2} \rrbracket^{g}=\llbracket \mathrm{Asp}_{2} \rrbracket^{g}\left(\llbracket \mathrm{VP} \rrbracket^{g}\right)=$ $\lambda P . \lambda i . \lambda w . \exists i^{\prime \prime}\left[i \subseteq i^{\prime \prime} \& P\left(i^{\prime \prime}\right)(w)\right](\lambda i . \lambda w$. João está na reunião em $i$ em $w)=$ $\lambda i . \lambda w . \exists i^{\prime \prime}: i \subseteq i^{\prime \prime} \&$ João está na reunião em $i^{\prime \prime}$ em $w$

2. $\llbracket \operatorname{ModP} \rrbracket^{g}=\llbracket \operatorname{Mod}_{\mathrm{CIRC}} \rrbracket^{g}\left(\llbracket \mathrm{AspP}_{2} \rrbracket^{g}\right)=$

$\lambda P . \lambda i . \lambda w \cdot \forall w^{\prime}\left[w^{\prime}\right.$ é compatível com as circunstâncias em $w$ em $i \longrightarrow$ $\left.P(i)\left(w^{\prime}\right)=1\right]\left(\lambda i \cdot \lambda w \cdot \exists i^{\prime \prime}\left[i \subseteq i^{\prime \prime} \&\right.\right.$ João está na reunião em $i^{\prime \prime}$ em $\left.\left.w\right]\right)=$ $\lambda i . \lambda w \cdot \forall w^{\prime}\left[w^{\prime}\right.$ é compatível com as circunstâncias em $w$ em $i \longrightarrow$ $\exists i^{\prime \prime}\left[i \subseteq i^{\prime \prime} \&\right.$ João está na reunião em $i^{\prime \prime}$ em $\left.\left.w^{\prime}\right]\right]$

3. $\llbracket \mathrm{AspP}_{1} \rrbracket^{g}=\llbracket \mathrm{Asp}_{1} \rrbracket^{g}\left(\llbracket \mathrm{ModP} \rrbracket^{g}\right)=$ $\lambda P . \lambda i . \lambda w . \exists i^{\prime}\left[i^{\prime} \supset i \& P\left(i^{\prime}\right)(w)\right]$

$\left(\lambda i . \lambda w . \forall w^{\prime}\left[w^{\prime}\right.\right.$ é compatível com as circunstâncias em $w$ em $i \longrightarrow$ $\exists i^{\prime \prime}\left[i \subseteq i^{\prime \prime} \&\right.$ João está na reunião em $i^{\prime \prime}$ em $\left.\left.\left.w^{\prime}\right]\right]\right)=$ $\lambda i . \lambda w . \exists i^{\prime}\left[i^{\prime} \supset i \& \forall w^{\prime}\left[w^{\prime}\right.\right.$ é compatível com as circunstâncias em $w$ em $i^{\prime} \longrightarrow$ $\exists i^{\prime \prime}\left[i^{\prime} \subseteq i^{\prime \prime} \&\right.$ João está na reunião em $i^{\prime \prime}$ em $\left.\left.\left.w^{\prime}\right]\right]\right]$

4. $\llbracket \mathrm{TP} \rrbracket^{g}=\llbracket \mathrm{AspP} \rrbracket^{g}\left(\llbracket \mathrm{T} \rrbracket^{g}\right)$

$\lambda i . \lambda w . \exists i^{\prime}\left[i^{\prime} \supset i \& \forall w^{\prime}\left[w^{\prime}\right.\right.$ é compatível com as circunstâncias em $w$ em $i^{\prime} \longrightarrow$ $\exists i^{\prime \prime}\left[i^{\prime} \subseteq i^{\prime \prime} \&\right.$ João está na reunião em $i^{\prime \prime}$ em $\left.\left.\left.w^{\prime}\right]\right]\right](g(i))=$ $\lambda w . \exists i^{\prime}\left[i^{\prime} \supset g(i) \& \forall w^{\prime}\left[w^{\prime}\right.\right.$ é compatível com as circunstâncias em $w$ em $i^{\prime} \longrightarrow$ $\exists i^{\prime \prime}\left[i^{\prime} \subseteq i^{\prime \prime} \&\right.$ João está na reunião em $i^{\prime \prime}$ em $\left.\left.\left.w^{\prime}\right]\right]\right]$

As condições de verdade de (191) podem ser informalmente parafraseadas da seguinte maneira: 
(192) a. Existe um intervalo de tempo $i^{\prime}$ que está completamente contido no tempo de referência contextualmente saliente $g(i)$, que, por sua vez, é anterior ao momento de fala.

b. Em todos os mundos possíveis compatíveis com as circunstâncias no mundo real em $i^{\prime}$, existe um terceiro intervalo de tempo, $i^{\prime \prime}$, que contém $i^{\prime}$. Nesses mundos, João está na reunião em $i^{\prime \prime}$.

Fazendo as alterações necessárias nas denotações de T, dos núcleos aspectuais e modais e, é claro, do VP, podemos chegar às denotações de sentenças com modais raiz com configurações temporais diferentes:

(193) (Até 2004), os alunos tinham que pegar um ônibus (para chegar à universidade).

Perspectiva: pretérito imperfectivo

Orientação: presente

$\llbracket$ Os alunos tinham que pegar um ônibus $\rrbracket^{g}=$

$\lambda w \cdot \exists i^{\prime}\left[g(i) \subseteq i^{\prime} \& \forall w^{\prime}\left[w^{\prime}\right.\right.$ é compatível com as circunstâncias em $w$ em $i^{\prime} \longrightarrow$

$\exists i^{\prime \prime}\left[i^{\prime} \subseteq i^{\prime \prime} \&\right.$ os alunos pegam um ônibus em $i^{\prime \prime}$ em $\left.\left.\left.w^{\prime}\right]\right]\right]$

(194) Os passageiros com destino ao terminal Butantã têm / terão que pegar um ônibus no próximo Domingo.

Perspectiva: presente

Orientação: futura

〔Os passageiros terão que pegar um ônibus $\rrbracket^{g}=$

$\lambda w \cdot \exists i^{\prime}\left[i^{*} \subseteq i^{\prime} \& \forall w^{\prime}\left[w^{\prime}\right.\right.$ é compatível com as circunstâncias em $w$ em $i^{\prime} \longrightarrow$ $\exists i^{\prime \prime}\left[i^{\prime \prime}>i^{\prime} \&\right.$ os passageiros pegam um ônibus em $i^{\prime \prime}$ em $\left.\left.\left.w^{\prime}\right]\right]\right]$

(195) Ingressantes no mestrado podem ter reprovado disciplinas.

Perspectiva: presente

Orientação: perfeita

$\llbracket$ Ingressantes no mestrado podem ter reprovado disciplinas $\rrbracket^{g}=$ $\lambda w . \exists i^{\prime}\left[i^{*} \subseteq i^{\prime} \& \exists w^{\prime}\left[w^{\prime}\right.\right.$ é compatível com as circunstâncias em $w$ em $i^{\prime} \&$ $\exists i^{\prime \prime}\left[i^{\prime \prime}<i^{\prime} \&\right.$ ingressantes no mestrado reprovam disciplinas em $i^{\prime \prime}$ em $\left.\left.\left.w^{\prime}\right]\right]\right]$ 


\subsubsection{Modais epistêmicos}

Passemos agora ao cálculo passo-a-passo dos exemplos envolvendo modais epistêmicos.

(196) Árvore para sentenças com modais epistêmicos

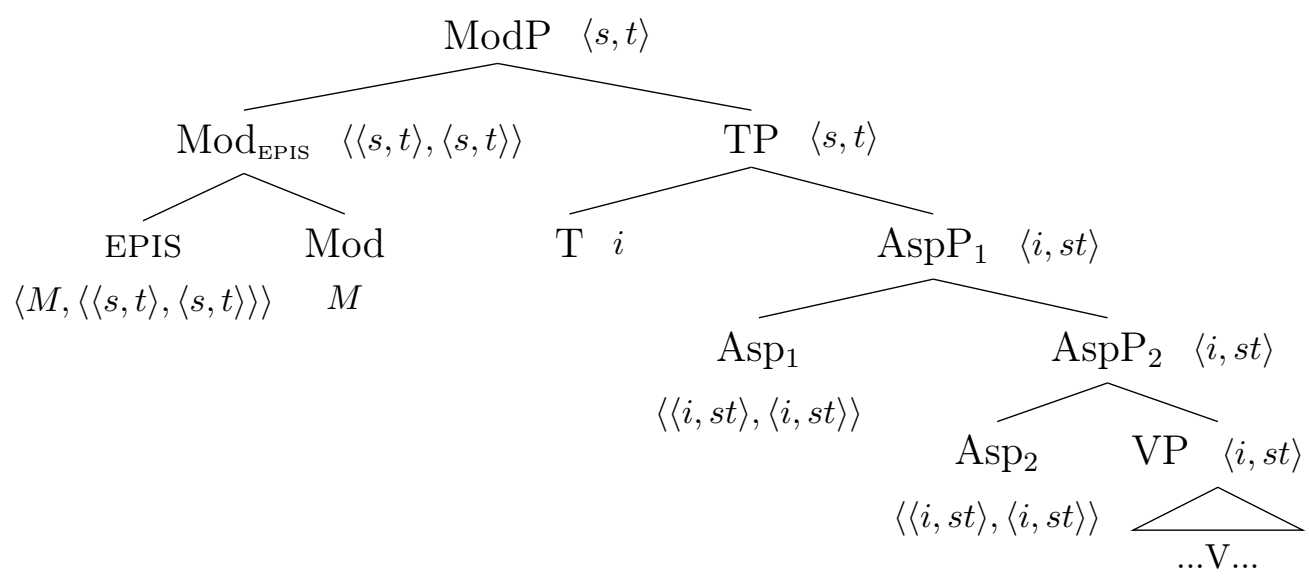

Nada de muito interessante acontece em relação à perspectiva temporal dos modais epistêmicos: ela sempre corresponde a $\tau_{g}$, que é a coordenada temporal de um contexto (Ferreira (2018)). No caso de orações matrizes, essa coordenada é o momento de fala. A única adição que faremos ao léxico será a denotação de $\operatorname{Mod}_{\mathrm{EPIS}}$, que, como vimos no capítulo 3, tem um tipo semântico diferente de $\operatorname{Mod}_{\text {CIRC }}$. As entradas lexicais que adotaremos para modais epistêmicos de necessidade $(\square)$ e possibilidade $(\diamond)$ são repetidas abaixo $^{19}$ :

(197) a. $\llbracket \square_{\text {epis }} \rrbracket^{g}=\lambda p_{\langle s, t\rangle} \cdot \lambda w \cdot \forall w^{\prime}\left[w^{\prime}\right.$ é compatível com as evidências em $w$ em $\tau_{g}$ $\left.\longrightarrow p\left(w^{\prime}\right)=1\right]$

b. $\quad \llbracket \diamond_{e p i s} \rrbracket^{g}=\lambda p_{\langle s, t\rangle} \cdot \lambda w \cdot \exists w^{\prime}\left[w^{\prime}\right.$ é compatível com as evidências em $w$ em $\tau_{g}$ $\left.\& p\left(w^{\prime}\right)=1\right]$

Para o cálculo passo-a-passo, escolhemos uma sentença com uma orientação temporal equivalente ao pretérito perfeito (Pretérito Mais-que-perfeito), por ser uma configuração temporal particularmente complexa, e indisponível para os modais raiz. Note que a sentença abaixo envolve dois núcleos aspectuais - PERF e IMP. Dentro da ontologia simplificada adotada para esta dissertação, esse empilhamento de núcleos aspectuais não será um problema. Sintagmas aspectuais são do tipo $\langle i, s t\rangle$ e núcleos aspectuais são do tipo $\langle\langle i, s t\rangle,\langle i, s t\rangle\rangle$, então eles podem se combinar por aplicação funcional. Matthewson (2012) constata a mesma combinação de sintagmas aspectuais em Gitksan. Remetemos o

\footnotetext{
${ }^{19}$ Lembre-se que essas entradas lexicais diferentes são obtidas a partir de entradas lexicais idênticas, logo, estão de acordo com os pressupostos do quadro teórico Kratzeriano.
} 
leitor ao seu trabalho para a apresentação de uma manobra que permite o empilhamento desses sintagmas mesmo em uma ontologia que contém eventos.

(198) O João (já) devia ter saído de casa (quando você chegou).

1. $\llbracket \mathrm{VP} \rrbracket^{g}=\llbracket[$ João sai de casa $] \rrbracket^{g}=\lambda i . \lambda w$. João sai de casa em $i$ em $w$

2. $\llbracket \mathrm{Asp}_{2} \rrbracket^{g}=\llbracket \mathrm{PERF} \rrbracket^{g}=\lambda P . \lambda i . \lambda w \cdot \exists i^{\prime \prime}\left[i^{\prime \prime}<i \& P\left(i^{\prime \prime}\right)(w)\right]$

3. $\llbracket \mathrm{Asp}_{1} \rrbracket^{g}=\llbracket \mathrm{IMP} \rrbracket^{g}=\lambda P \cdot \lambda i \cdot \lambda w \cdot \exists i^{\prime}\left[i \subseteq i^{\prime} \& P\left(i^{\prime}\right)(w)\right]$

4. $\llbracket$ dever $_{\text {epis }} \rrbracket^{g}=\lambda p_{\langle s, t\rangle} \cdot \lambda w \cdot \forall w^{\prime}\left[w^{\prime}\right.$ é compatível com as evidências em $w$ em $\tau_{g}$ $\left.\longrightarrow p\left(w^{\prime}\right)=1\right]$

5. $\llbracket \mathrm{T} \rrbracket^{g}=\llbracket \mathrm{PRET}_{i} \rrbracket^{g}= \begin{cases}g(i) & \text { se } g(i)<\text { momento de fala } \\ \text { indefinido } & \text { nos demais casos }\end{cases}$

6. $\llbracket \mathrm{AspP}_{2} \rrbracket^{g}=\llbracket \mathrm{Asp}_{2} \rrbracket^{g}\left(\llbracket \mathrm{VP} \rrbracket^{g}\right)=$ $\lambda P . \lambda i . \lambda w . \exists i^{\prime \prime}\left[i^{\prime \prime}<i \& P\left(i^{\prime \prime}\right)(w)\right](\lambda i . \lambda w$. João sai de casa em $i$ em $w)=$ $\lambda i . \lambda w \cdot \exists i^{\prime \prime}\left[i^{\prime \prime}<i \&\right.$ João sai de casa em $i^{\prime \prime}$ em $\left.w\right]$

7. $\llbracket \mathrm{AspP}_{1} \rrbracket^{g}=\llbracket \mathrm{Asp}_{1} \rrbracket^{g}\left(\llbracket \mathrm{AspP}_{2} \rrbracket^{g}\right)=$ $\lambda P . \lambda i . \lambda w . \exists i^{\prime}\left[i \subseteq i^{\prime} \& P\left(i^{\prime}\right)(w)\right]\left(\lambda i . \lambda w . \exists i^{\prime \prime}\left[i^{\prime \prime}<i^{\prime} \quad \&\right.\right.$ João sai de casa em $i^{\prime \prime}$ em $\left.\left.w\right]\right)=$ $\lambda i . \lambda w . \exists i^{\prime}\left[i \subseteq i^{\prime} \& \exists i^{\prime \prime}\left[i^{\prime \prime}<i^{\prime} \quad \&\right.\right.$ João sai de casa em $i^{\prime \prime}$ em $\left.\left.w\right]\right]$

8. $\llbracket \mathrm{TP} \rrbracket^{g}=\llbracket \mathrm{AspP}_{1} \rrbracket^{g}\left(\llbracket \mathrm{T} \rrbracket^{g}\right)=$ $\lambda w \cdot \exists i^{\prime}\left[g(i) \subseteq i^{\prime} \& \exists i^{\prime \prime}\left[i^{\prime \prime}<i^{\prime} \quad \& \quad\right.\right.$ João sai de casa em $i^{\prime \prime}$ em $\left.\left.w\right]\right]$

9. $\llbracket \mathrm{ModP} \rrbracket^{g}=\llbracket$ dever $_{\text {epis }} \rrbracket^{g}\left(\llbracket \mathrm{TP} \rrbracket^{g}\right)=$ $\lambda w . \forall w^{\prime}\left[w^{\prime}\right.$ é compatível com as evidências em $w$ em $\tau_{g}$ $\longrightarrow \exists i^{\prime}\left[g(i) \subseteq i^{\prime} \& \exists i^{\prime \prime}\left[i^{\prime \prime}<i^{\prime} \quad \&\right.\right.$ João sai de casa em $i^{\prime \prime}$ em $\left.\left.w^{\prime}\right]\right]$

Nos cálculos acima, $\tau_{g}$ corresponde ao momento de fala, e é responsável por fixar a perspectiva temporal de dever. O segundo intervalo, $g(i)$ corresponde ao pretérito, ou seja, as condições de verdade de (198) só serão definidas se o contexto de uso fornecer um intervalo de tempo saliente anterior ao momento de fala. Esse intervalo $g(i)$ está contido em $i^{\prime}$, por contribuição do aspecto imperfectivo. Finalmente, o quarto intervalo, $i^{\prime \prime}$, é anterior a $i^{\prime}$ e corresponde ao momento em que João saiu de casa nos mundos possíveis compatíveis com as evidências no mundo real.

Fazendo as devidas alterações lexicais, obtemos as condições de verdade de sentenças com modais epistêmicos com diferentes orientações temporais: 
(199) A Maria pode estar no trabalho.

Perspectiva: presente

Orientação: presente

【A Maria pode estar no trabalho $\rrbracket^{g}=\lambda w \cdot \forall w^{\prime}\left[w^{\prime}\right.$ é compatível com as evidências em $w$ em $\tau_{g} \longrightarrow \exists i^{\prime}\left[i^{*} \subseteq i^{\prime} \quad \&\right.$ Maria está no trabalho em $i^{\prime}$ em $\left.\left.w^{\prime}\right]\right]$

(200) O João deve(rá) se atrasar.

Perspectiva: presente

Orientação: futura

〔O João deverá se atrasar $\rrbracket^{g}=\lambda w \cdot \forall w^{\prime}\left[w^{\prime}\right.$ é compatível com as evidências em $w$ em $\tau_{g} \longrightarrow \exists i^{\prime}\left[i^{\prime}>g(i) \quad \&\right.$ João se atrasa em $i^{\prime}$ em $\left.\left.w^{\prime}\right]\right]$

(201) O João poderia ter uma reunião com o chefe mais tarde.

Perspectiva: presente

Orientação: Futuro do pretérito

〔O João poderia ter uma reunião com o chefe mais tarde $\rrbracket^{g}=$ $\lambda w . \exists w^{\prime}\left[w^{\prime}\right.$ é compatível com as evidências em $w$ em $\tau_{g} \& \exists i^{\prime}\left[g(i) \subseteq i^{\prime} \& \exists i^{\prime \prime}\left[i^{\prime \prime}>\right.\right.$ $i^{\prime} \quad \&$ João tem uma reuniao com o chefe em $i^{\prime \prime}$ em $\left.w^{\prime}\right]$ ]

\subsubsection{Conclusão da seção}

Esta seção teve como objetivo fornecer uma análise formal e composicional da interação entre verbos modais e expressões temporais no PB. Para esse fim, adotamos as ferramentas teóricas de Ferreira (2018), aplicando-as às nossas conclusões sobre a composição morfológica do prejacente de verbos modais epistêmicos e raiz. O resultado mais importante dessa seção foi que a orientação temporal de um verbo modal é determinada exclusivamente pelo núcleo temporal e pelos operadores aspectuais sob seu escopo. Isto significa que não precisamos fazer qualquer adição à entrada lexical dos modais ou recorrer a princípios interpretativos, como fizeram Condoravdi (2002) e Werner (2006), respectivamente, para capturar a orientação temporal de verbos modais.

Isto responde à primeira das duas perguntas com as quais abrimos essa dissertação: 
Quais morfemas entram para a computação da perspectiva e da orientação temporal em sentenças com os verbos modais poder, dever e ter que no PB?

A segunda pergunta, repetida abaixo, já foi respondida tangencialmente ao longo dos capítulos 2,3 e 4 .

Existem restrições à perspectiva ou à orientação temporal de modais epistêmicos ou raiz? Se sim, qual a natureza dessas restrições?

Como modais epistêmicos e raiz apresentam uma diferença de altura, as duas classes de modais utilizam o núcleo temporal das sentenças de maneiras distintas. No caso de modais raiz, T entra para o cálculo de sua perspectiva temporal, e apenas núcleos aspectuais entram para o cálculo de sua orientação. Como consequência, o deslocamento temporal sob esses modais sempre se dá em relação à sua perspectiva, podendo ser concomitante, posterior ou anterior a ela, a depender do operador aspectual sob o escopo do modal. Ou seja, modais raiz não podem ter uma orientação verdadeiramente passada. Modais epistêmicos, no entanto, utilizam T para determinar sua orientação temporal, o que permite que esses modais tenham orientações temporais mais complexas, incluindo orientações passadas. Sua perspectiva, por outro lado, é fixada no momento de fala.

Entretanto, como sugerimos no capítulo 2, existe pelo menos uma restrição à interpretação temporal de sentenças modais que resiste a tratamentos puramente sintáticos a impossibilidade de modais epistêmicos de necessidade serem orientados ao futuro. Essa restrição foi a motivação inicial para o trabalho de Werner (2006). Uma vez que assumimos que a orientação temporal emerge apenas de morfemas sob o escopo do modal, e não de mecanismos pragmáticos, perdemos também o poder explicativo da teoria de Werner (2006) com respeito a essa restrição. Com isso em mente, a próxima seção será dedicada a uma revisão de trabalhos anteriores sobre restrições à orientação temporal de modais e ao esboço de uma análise que explique por que modais epistêmicos não podem ter orientação futura.

\subsection{Restrições à orientação temporal de verbos modais}

Iniciaremos essa seção relembrando o trabalho de Werner (2006). O autor se baseou na aparente correlação entre base modal e orientação temporal em exemplos como (173) e (174), repetidos abaixo como (202) e (203), para propor que base modal e orientação temporal estariam em co-variação. 
(202) Janet must live in student housing.

janete tem que morar em aluno alojamento

'A Janete tem que morar no alojamento estudantil.'

(203) John can't be our representative.

joão não pode ser nosso representante

'O João não pode ser nosso representante.'

A generalização é que quando essas sentenças são utilizadas em contextos que favorecem uma leitura epistêmica para os modais must e can't, a orientação temporal das sentenças é inevitavelmente presente. Quando os mesmos modais combinam-se com uma base modal circunstancial, a orientação temporal é obrigatoriamente futura.

Werner (2006) não é o único autor a assumir essa generalização. Observando tanto verbos modais quanto verbos de atitude proposicional, Klecha (2016) também propõe que exista co-variação entre base modal e orientação temporal. O autor baseia sua análise em exemplos como (204):

(204) Vai chover o dia todo.

O objetivo principal de Bill é não se molhar.

Ele terá que ficar fora de casa o dia todo.

a. He has to wear a raincoat.

ele tem que usar uma capa de chuva

b. He has to be wearing a raincoat when he leaves.

ele tem que estar usando uma capa de chuva quando ele sair

c. He has to be wearing a raincoat right now.

ele tem que estar usando uma capa de chuva agora

d. He has to have worn a raincoat.

ele tem que ter usado uma capa de chuva

Nas sentenças (204a) e (204b), a base modal é circunstancial e a fonte de ordenação é teleológica. A orientação do modal é obrigatoriamente futura. Nas sentenças (204c) e (204d), o modal se combina com uma base modal epistêmica - nesse caso, as circunstâncias e os objetivos de Bill servem como evidência de seu comportamento. A orientação é presente em (204c) e perfeita em (204d).

Embora nos exemplos em (204) os modais raiz sejam teleológicos, o autor observa o mesmo comportamento em contextos que favorecem uma interpretação deôntica, como aqueles em (205). O fator determinante para a obrigatoriedade de uma orientação futura 
parece ser a combinação com uma base modal circunstancial. Novamente, a generalização é que modais epistêmicos têm orientação presente ou perfeita, enquanto modais raiz têm orientação obrigatoriamente futura.

(205) Ele sabe as regras...

$$
\begin{aligned}
& \text { a. \# He has to / must have done the dishes last Tuesday. } \\
& \text { ele tem que / deve ter lavado os pratos última terça } \\
& \text { b. \# He has to / must be doing the dishes right now. } \\
& \text { ele tem que / deve estar lavando os pratos agora } \\
& \text { c. He has to / must do the dishes next Tuesday. } \\
& \text { ele tem que / deve lavar os pratos próxima terça }
\end{aligned}
$$

As semelhanças entre as propostas de Klecha (2016) e Werner (2006) estão limitadas a essa generalização. Enquanto Werner (2006) se baseia em princípios pragmáticos, Klecha (2016) adota uma abordagem semântica. A proposta central do autor é de que as bases modais seriam dotadas também de informações temporais que limitariam as possibilidades interpretativas dos prejacentes. Note que, de acordo com essa teoria, modais não seriam capazes de manipular a interpretação temporal de seus prejacentes, apenas limitá-la. A orientação temporal seria proveniente de morfemas alojados no prejacente, conforme propomos nessa dissertação. Os modais apenas selecionariam os tipos de prejacentes com os quais podem ser combinar.

Embora Klecha (2016) explique esse comportamento através de adições à semântica das bases modais, o autor sugere que ele teria raízes pragmáticas: Pessoas só podem ter certeza sobre conhecimentos presentes ou passados, mas não futuros, o que, em consonância com a Máxima de Qualidade (Grice (1975)), bloquearia a orientação futura em sentenças com modais epistêmicos. Por outro lado, as noções normalmente transmitidas por modais raiz, como desejos, regras e objetivos, seriam naturalmente orientadas para o futuro. Na prova subseção, revisaremos a contribuição do PB para essa discussão.

\subsubsection{Restrições à orientação temporal no PB}

\section{Modais raiz}

De acordo com as teorias de Werner (2006) e Klecha (2016), sentenças com modais raiz só admitiriam orientações futuras. Como já deve estar claro para o leitor, nós discordamos desse ponto.

Um primeiro indício de que as generalizações adotadas pelos autores estão equivocadas vem de sentenças em que o modal raiz recebe morfologia de pretérito perfectivo. Nesses casos, sua orientação temporal parece ser obrigatoriamente presente - o que significa que a 
proposição prejacente $\varphi$ é interpretada como acontecendo concomitantemente ao momento da obrigação, objetivo, etc. Isto é, uma sentença como (206) implica que Maria teve a obrigação de fazer o trabalho da chefe dela em algum intervalo passado específico, e ela de fato realizou essa obrigação dentro desse intervalo ${ }^{20}$.

(206) A Maria teve que fazer o trabalho do chefe dela.

Embora o aspecto perfectivo origine orientações obrigatoriamente presentes com modais raiz, ele não é condição sine qua non para que essas leituras sejam obtidas. O próprio Klecha (2016), atribui um exemplo ${ }^{21}$ a Kai von Fintel no qual o modal de necessidade have to, com morfologia de presente, também admite uma orientação concomitante à sua perspectiva:

(207) I'm here because I have to be.

eu estou aqui porque eu tenho que estar

O autor no entanto desafia a legitimidade dessa sentença enquanto contraexemplo à sua generalização, pois acredita que a orientação presente nesse caso é licenciada por alguma sutileza da fonte de ordenação de have to.

A chamada orientação passada, que nessa dissertação optados por chamar de orientação perfeita, também está disponível para sentenças com modais raiz. Trata-se de uma segunda configuração temporal não-prevista pela generalização de Werner (2006) e Klecha (2016):

(208) Os alunos têm que ter cursado Elementos da Linguística antes de cursar Sintaxe.

É importante ressaltar que a interpretação temporal de exemplos como (208) é distinta da interpretação de (209). Como Klecha (2016) aponta, (209) ${ }^{22}$ é um caso de perspectiva passada e orientação futura. A regra em questão já estava em vigor em um ponto do passado anterior à terça-passada, logo, o momento em que essa regra foi infringida é posterior ao momento da perspectiva.

(209) You know the rules; you should've done the dishes last Tuesday. você sabe as regras; você deveria ter lavado os pratos última terça

Lembre-se que a perspectiva temporal de modais raiz no PB é marcada no próprio modal. Para que a sentença (208) tivesse perspectiva passada e orientação futura, o modal ter que deveria receber morfologia de pretérito, como em (210).

\footnotetext{
${ }^{20}$ Remetemos o autor aos trabalhos de Bhatt (1999) e Hacquard (2006) para duas teorias que buscam explicar por que modais raiz geram leituras de actuality entailment.

${ }^{21}$ Nota de rodapé (9) em Klecha (2016).

${ }^{22}$ Exemplo (14) em Klecha (2016).
} 
(210) Os alunos tinham que ter cursado Elementos da Linguística antes de cursar Sintaxe.

Sem dúvidas, sentenças em que modais raiz têm orientação presente ou perfeita não são abundantes nas línguas naturais. Acreditamos que isso seja uma consequência das noções expressas por modais raiz: desejos, obrigações e objetivos são naturalmente orientados para o futuro. Atribuir essa tendência extra-linguística a princípios interpretativos ou codificá-la no léxico nos parece uma manobra forte demais, que leva à subgeração.

Com isso, concluímos que as restrições previstas por Werner (2006) and Klecha (2016) com relação à orientação temporal de sentenças com modais raiz não são operantes no PB. Na próxima subseção, apresentaremos os dados de modais epistêmicos.

\section{Modais epistêmicos}

Ao contrário dos modais raiz, modais epistêmicos de fato apresentam uma restrição. Essa restrição, no entanto, é muito mais circunscrita do que se prevê na literatura. Apenas asserções modais que expressam necessidade bloqueiam prejacentes orientados ao futuro. Esse é o caso, por exemplo, de orações com o modal ter que.

Antes de prosseguirmos com essa discussão, é importante distinguirmos exemplos envolvendo futurados daqueles envolvendo uma orientação verdadeiramente futura. De acordo com Copley (2009), futurados são asserções sobre planos presentes para a obtenção de resultados futuros. Esse é o caso, por exemplo da sentença (211a). A sentença (211b), formada a partir do prejacente de (211a), é um teste para avaliarmos se esse prejacente é realmente orientado ao futuro ou se é apenas um futurado. O fato de que essa sentença tem interpretação futura mesmo no Presente Simples, indica que (211a) não tem orientação futura.

(211) a. As aulas devem começar semana que vem.

b. As aulas começam semana que vem.

Compare os exemplos em (211) aos exemplos em (212). Note que, com prejacentes realmente orientados ao futuro, é impossível criar orações matriz no Presente Simples que preservem a futuridade. A interpretação do predicado de (212b) é habitual, o que torna a sentença pragmaticamente inadequada.

(212) a. Eu devo me atrasar para a reunião.

b.\#Eu me atraso para a reunião.

Apenas prejacentes com orientação futura, não futurada, são incompatíveis com modais de necessidade epistêmica, como é ilustrado pelos exemplos em (213). Sendo assim, exemplos futurados não nos interessam nessa seção. 
(213) a. A: Você sabe quando as nossas aulas começam?

B: As aulas têm que começar amanhã. Todas as turmas começam amanhã.

b.\#A: Você acha que você chegará a tempo para a festa?

B: Eu devo / \#tenho que me atrasar. O trânsito está parado.

Como vimos no capítulo 2, o modal poder, sob o escopo da negação, também não pode ser orientado ao futuro. Isso nos protege do argumento de que essa restrição seria uma idiossincrasia de ter que. Realmente parece se tratar de uma restrição sistemática da língua.

Os dados do PB nos mostram que, se assumirmos co-variação entre base modal e orientação temporal, não seríamos capazes de prever diversas formas atestadas na língua: Modais raiz podem ter orientação presente ou perfeita, e modais epistêmicos podem ser orientados ao futuro, desde que não expressem necessidade. A generalização correta sobre a correlação entre base modal e orientação temporal é muito mais específica do que a proposta por Werner (2006) e Klecha (2016):

\section{Correlação entre base modal e orientação temporal}

Asserções epistêmicas com verbos modais que expressam necessidade não podem ser orientadas ao futuro.

Na próxima seção, apresentaremos uma análise que derive essa propriedade dos epistêmicos universais sem levar à subgeração.

\subsubsection{Um caminho de análise}

Antes de tentarmos explicar a restrição que identificamos na última seção, vamos apresentar uma complicação adicional: e se existirem modais epistêmicos universais que não apenas podem, mas devem ser orientados ao futuro? A resposta a essa pergunta depende crucialmente de certos pressupostos sobre a natureza do próprio futuro nas línguas naturais.

A visão de que o futuro seria um modal, não um Tempo, é bastante comum entre pesquisadores, e encontra apoio em diversas assimetrias entre os Tempos presente e pretérito e o futuro ${ }^{23}$. Isso leva à pergunta: se o futuro é um modal, qual seria o tipo de modalidade expressada por ele? Temos pelo menos duas boas candidatas - a modalidade epistêmica e a modalidade metafísica.

Uma análise metafísica para o futuro se basearia em um modelo de mundos ramificados (Thomason (1984)). Já apresentamos esse modelo quando discutimos a teoria de Werner (2006), mas vamos revisar suas características principais. De acordo com esse modelo,

\footnotetext{
${ }^{23} C f$. Enç (1996) para uma apresentação das assimetrias entre presente, passado e futuro que motivam o tratamento do futuro como modal.
} 
o passado seria constituído por um único galho que se ramificaria em direção ao futuro. Para cada momento $t$, diremos que as alternativas históricas de $h_{0}{ }^{24}$ em $t$ são os cursos históricos que são iguais a $h_{0}$ até $t$. O conjunto $H(t)$, de alternativas históricas de $h$ em $t$, pode ser definido da seguinte maneira:

$$
H(t):=\left\{h \mid h \simeq_{t} h_{0}\right\}
$$

Aplicando essa definição ao modelo ilustrado em 4.2, temos:
a. $H\left(t_{1}\right):=\left\{h_{1}, h_{2}, h_{3}, h_{4}, h_{5}\right\}$
b. $H\left(t_{2}\right):=\left\{h_{2}, h_{3}, h_{4}, h_{5}\right\}$
c. $H\left(t_{3}\right):=\left\{h_{2}, h_{3}, h_{4}\right\}$

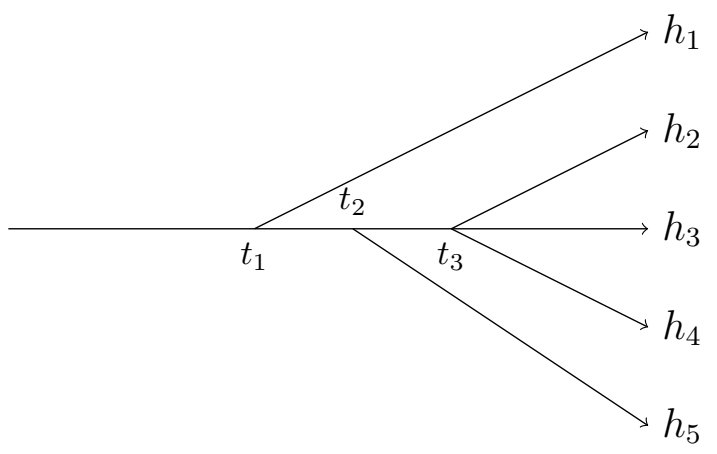

Figura 4.2: Modelo de mundos ramificados de Thomason (1984)

Giannakidou e Mari (2018) mostram que, mesmo se adotarmos um tratamento metafísico para as previsões, precisamos, de alguma forma, incluir referências ao estado epistêmico do falante, afinal, previsões dependem do conhecimento de quem as faz. Seguindo Giannakidou e Mari (2013), as autoras implementam essa ideia através da inclusão do chamado Critério Futuro $^{25}$, representado por $\mathcal{E}$, à semântica dos modais metafísicos. Para ilustração da relevância do Critério Futuro, considere o seguinte cenário: João e Maria estão esperando seu amigo, Pedro, que acabou de sair de casa. São 3h40 da tarde. Maria $\operatorname{diz}^{26}$ :

O Pedro vai chegar às 4 da tarde.

Ao proferir (217), Maria se baseou no seu conhecimento sobre o mundo, que inclui fatos sobre o trânsito, generalizações baseadas em experiências pessoais, etc. Ela sabe que às 4 da tarde ainda não começou a hora do rush, que o trânsito é leve fora da hora do rush e que o percurso entre a casa de Pedro e o local em que estão pode ser percorrido

\footnotetext{
${ }^{24}$ Sendo $h_{0}$ o curso histórico que contém o passado e o presente de $w$, o mundo real.

${ }^{25}$ Future Criterion, no original.

${ }^{26}$ Cenário e exemplos baseados em Giannakidou e Mari (2018).
} 
em vinte minutos quando o trânsito está leve. Sendo assim, o critério futuro de Maria é composto pelo seguinte conjunto de proposições:

(218) $\mathcal{E}_{\text {Maria }}=\{$ 'às 4 da tarde ainda não começou a hora do rush', 'o trânsito é leve fora da hora do rush', 'o percurso entre a casa de Pedro e o local em que estamos pode ser percorrido em vinte minutos quando o trânsito está leve'\}

Suponha, no entanto, que o João tem uma informação que Maria não tem - há uma construção no caminho entre a casa de Pedro e o local em que estão. Seu critério futuro incluirá mais proposições que o de Maria:

(219) $\mathcal{E}_{\text {João }}=\{$ 'às 4 da tarde ainda não começou a hora do rush', 'o trânsito é leve fora da hora do rush', 'o percurso entre a casa de Pedro e o local em que estamos pode ser percorrido em vinte minutos quando o trânsito está leve', 'está ocorrendo uma construção no caminho entre a casa do Pedro e nosso ponto de encontro', 'construções tornam o tráfego mais lento'\}

Com base em $\mathcal{E}_{\text {João }}$, João discorda de Maria:

(220) Não, o Pedro vai chegar às 5 da tarde.

Esse exemplo mostra claramente que previsões são subjetivas, e estão condicionadas ao conhecimento dos falantes que as fazem. Ainda assim, Giannakidou e Mari (2018) propõem que é possível adotarmos uma análise metafísica para o futuro, desde que o critério futuro seja adicionado às condições de verdade das sentenças, na forma de uma fonte de ordenação. Segundo as autoras, o empecilho realmente intransponível para a análise metafísica é a existências de previsões baseadas somente no conhecimento do falante.

Imagine um cenário idêntico ao que acabamos de descrever, exceto por um acréscimo: Pedro sofreu um acidente fatal de carro no caminho ao ponto de encontro com seus amigos. Não estando cientes do acontecimento, Maria e João poderiam fazer as previsões em (217) e (220) embora não exista nenhuma alternativa histórica de $h_{0}$ no momento de fala em que essas previsões se confirmem. Nesse caso, Maria e João se basearam apenas no seu conhecimento.

A análise do futuro como modal epistêmico encontra ainda respaldo no uso puramente epistêmico (não-preditivo) das marcações de futuro, que Giannakidou e Mari (2018) mostram ocorrer no italiano (exemplo (223)) e no grego (exemplo (224)) $)^{27}$ :

\footnotetext{
${ }^{27}$ Giannakidou e Mari (2018) apontam que o uso do futuro puramente epistêmico no inglês é controverso. Embora falantes julguem a sentença (221) como sendo gramatical, eles também julgam o exemplo (222) como sendo ruim.
} 
$(223)$

Giacomo ora starà mangiando.

giacomo agora estar ${ }_{\mathrm{FUT}}$ comendo

'Giacomo deve estar comendo agora.'

[Exemplo (12b) em Giannakidou e Mari (2018)]

(224) Dhen ine sto sxolio. Tha ine arrostos.

não está na escola. FUT estar doente

'Ele não está na escola. Ele deve estar doente.'

[Exemplo (130a) em Giannakidou e Mari (2018)]

Em resumo, as evidências trazidas por Giannakidou e Mari (2018) sugerem que uma análise do futuro como um modal epistêmico talvez seja mais promissora do que como um modal metafísico. Se esse for mesmo o caso, a generalização que fizemos no capítulo anterior está equivocada, afinal, o futuro seria um modal de força universal, com sabor epistêmico, que pode ser orientado ao futuro.

Segundo as autoras, essa generalização seria fruto exatamente da existência desse modal epistêmico futuro. O futuro seria a forma não-marcada de fazermos previsões de força universal. Quando o futuro é codificado na forma de um verbo modal, como é o caso do will do inglês, ele entraria em competição com outros verbos modais epistêmicos e universais orientados ao futuro, e bloquearia o uso dessas outras formas. É como se fosse esperado que o falante utilize will para fazer previsões sobre o futuro. Em línguas como o italiano, nas quais o futuro é um morfema que se adjunge a outros verbos, e não um verbo modal, não ocorreria esse tipo de bloqueio.

Vejamos como essa análise acomoda os dados do PB. O PB conta com duas formas para o futuro do modo indicativo: o futuro perifrástico com ir e o futuro sintético, que já praticamente caiu em desuso na língua falada:

(225) a. Vai chover logo.

b. Choverá logo.

(221) That will be the postman.

aquele FUT ser o carteiro

'Deve ser o carteiro.'

(222) \# He is not at school. He will be ill. ele está não na escola. Ele FUT estar doente

'Ele não está na escola. Ele deve estar doente.'

Citando Mari (2016), as autoras propõem que o uso aparentemente presente do auxiliar futuro em (221) seria, na verdade, um exemplo do chamado futuro ratificacional, um futuro epistêmico que exige que haja um tempo futuro de verificação. 
O futuro perifrástico é composto pelo auxiliar ir, que parece um bom candidato para ser a contraparte de will no PB, e, como consequência, entrar em competição com ter que. O futuro sintético é formado pela adição do morfema $-r$ - ao verbo principal.

Um fato curioso sobre o futuro perifrástico é que o auxiliar ir também admite opcionalmente a marcação futura típica do futuro sintético, como já sinalizamos no capítulo 2:

(226) a. O João vai se atrasar.

b. O João irá se atrasar.

Nesse ponto, poderíamos adotar duas análises distintas para essas formas futuras. O primeiro caminho de análise seria assumirmos que só o auxiliar do futuro perifrástico é de natureza modal, ao passo que a marcação de futuro do futuro sintético seria apenas temporal - a realização do aspecto prospectivo, como temos assumido ao longo desta dissertação. A vantagem dessa análise é que ela oferece uma explicação bastante simples para a marcação de futuro opcional no auxiliar ir. Da mesma forma que temos assumido que a orientação futura dos modais é oriunda de um morfema de aspecto prospectivo, assumiríamos que a orientação futura de ir também emerge de um morfema que pode ou não ser realizado abertamente. Nesse caso, ir apresentaria uma especificidade em relação ao futuro do italiano e do grego e aos demais modais do PB, afinal sua orientação é obrigatoriamente futura. Sentenças com leituras puramente epistêmicas não-preditivas do futuro, como (223) e (224), não são possíveis no PB com qualquer forma futura ${ }^{28}$ :

$$
\begin{aligned}
& \text { a.\# O João não está na escola. Ele estará doente. } \\
& \text { b.\#O João não está na escola. Ele vai estar doente. }
\end{aligned}
$$

Poderíamos construir essa particularidade do auxiliar ir na forma de uma pressuposição que exija que a proposição que o modal toma como argumento seja realizada em um momento posterior ao da perspectiva do modal. De acordo com os pressupostos que adotamos passa esse trabalho, isso significaria que o modal exige um prejacente que contenha o aspecto prospectivo. Uma consequência indesejável dessa análise é que ela implica em uma diferença semântica entre as formas do futuro, o que não nos parece condizer com os julgamentos de falantes.

Uma alternativa seria assumirmos que tanto o auxiliar ir quanto a marcação de futuro sintético são de natureza modal. Nesse caso, a forma irei seria considerada um exemplo de concordância modal, ou seja, uma forma composta por dois elementos modais sendo interpretados como um só. Como Lunguinho (2010) mostra, a concordância modal ocorre quando um dos elementos envolvidos é um auxiliar modal e quando os dois elementos compartilham força e sabor modal. A forma irei obedece essas duas exigências.

\footnotetext{
${ }^{28}$ Uma exceção é a forma será, que parece estar fossilizada na língua.
} 
Uma análise aprofundada sobre as diferenças entre o futuro perifrástico e o futuro sintético está muito além do escopo desta pesquisa. O ponto crucial da discussão que conduzimos nessa seção é que nos parece razoável adotarmos uma análise do futuro no PB como um modal epistêmico, seguindo Giannakidou e Mari (2018). Como o futuro perifrástico é formado por um auxiliar, teríamos um auxiliar modal de necessidade na língua que seria especializado em leituras epistêmicas orientadas ao futuro. Sendo essa forma a forma não-marcada de referência futura, ela bloquearia outros auxiliares modais de necessidade epistêmica orientados ao futuro. Uma sentença com ter que em sua leitura epistêmica orientado ao futuro teria condições de verdade idênticas às de uma sentença com o futuro perifrástico. Sendo assim, quando um falante utiliza o modal ter que com orientação futura, seu interlocutor infere que ele tem uma leitura não-epistêmica em mente. A mesma lógica pode ser aplicada às sentenças com o auxiliar poder sob o escopo da negação: quando um falante escolhe dizer não pode chover, em vez de não vai chover, seu falante infere que ele não quis utilizar um modal epistêmico.

Se a proposta de Giannakidou e Mari (2018) está no caminho certo, esperamos que nas línguas em que o futuro pode ser expressado por um auxiliar, modais de necessidade com orientação futura não possam ser interpretados com uma leitura epistêmica. Em línguas nas quais o futuro é codificado na forma de morfemas adjungidos ao verbo, esses morfemas não entrariam em competição com verbos modais de necessidade e esses modais admitiriam leituras epistêmicas orientadas ao futuro. O PB tem as duas formas de futuro, embora uma delas esteja caindo em desuso. Assumimos, então, que o futuro perifrástico é o responsável por bloquear o ter que epistêmico com orientação futura. É necessário que façamos mais pesquisas translinguísticas para verificar se as previsões feitas aqui se confirmam.

\subsection{Conclusão}

Esse capítulo foi dedicado a uma investigação sobre a fonte da orientação temporal em sentenças com modais. Assumimos que a orientação temporal nunca é contribuição do próprio modal, o que nos permitiu manter uma semântica austera para esses verbos. A orientação temporal tampouco emerge de princípios pragmáticos, como proposto por Werner (2006), visto que identificamos todos os operadores sob o escopo do modal que são responsáveis por deslocar a interpretação temporal de seu prejacente. Identificamos também uma assimetria entre a composição do prejacente de modais epistêmicos e modais raiz. O núcleo temporal em sentenças com modais epistêmicos junta-se aos operadores aspectuais sob o escopo do modal para compor sua orientação temporal. Essa propriedade é um efeito direto da diferença de altura entre modais epistêmicos e raiz em relação ao Tempo, e explica por que orientações verdadeiramente passadas estão indisponíveis 
para modais raiz. Nossas descobertas foram aplicadas a uma análise composicional da interpretação temporal de sentenças modais.

Uma vez que dispensamos os princípios pragmáticos que Werner (2006) propõe serem responsáveis pela emergência da orientação temporal, também perdemos o poder explicativo de sua teoria com respeito às restrições à orientação temporal. Na seção 4.4, mostramos que talvez isso não seja uma consequência indesejável, visto que a proposta de Werner (2006) leva à subgeração. A única restrição que acreditamos ser operante no PB é a impossibilidade de modais epistêmicos que expressam necessidade serem orientados ao futuro. Para explicar essa restrição, adotamos a proposta de Giannakidou e Mari (2018), segundo a qual, a leitura epistêmica de modais de necessidade seria bloqueada pela existência de um auxiliar modal especializado em leituras futuras.

Essa análise se baseou em vários pressupostos - que o futuro nas línguas naturais é um modal, que esse modal é epistêmico, que ele é capaz de bloquear o uso epistêmico orientado ao futuro de outros verbos modais. Embora o tratamento do futuro como um modal seja bastante aceito na literatura, a ideia de que a modalidade expressa por ele é epistêmica não é uma visão tão comum. Werner (2006), Copley (2009), entre muitos outros, propõem que o futuro seria um modal metafísico. Explorar a fundo a natureza do futuro está fora do escopo deste trabalho. Nosso propósito é apenas mostrar que não precisamos adotar uma teoria baseada em co-variação entre base modal e orientação temporal para explicar a interpretação dos prejacentes de sentenças modais - uma análise puramente sintática, aliada à proposta de um efeito de bloqueio nos permite uma cobertura adequada dos dados. 


\section{Capítulo 5}

\section{Considerações finais}

Do ponto de vista semântico, o PB é uma língua ainda pouco descrita. Se levarmos em conta apenas trabalhos sobre modalidade, tempo, e a interação entre esses dois domínios, essa lacuna empírica torna-se ainda maior. O propósito principal desta pesquisa foi ajudar a preencher essa lacuna, fornecendo uma descrição panorâmica de interações entre verbos modais, tempo e aspecto no PB.

Dividimos esta dissertação em duas partes. No capítulo 3, apresentamos o que o PB tem a nos dizer sobre como modais fixam sua perspectiva temporal. Embora a posição que adotamos seja de longe a mais comum entre pesquisadores, talvez os dados do PB tenham algo a adicionar à discussão, visto que eles mostram com bastante clareza que a morfologia tempo-aspectual adjungida aos modais epistêmicos é interpretada sob seu escopo. Isso nos permitiu propor uma diferença de altura entre modais epistêmicos e raiz sem nos basearmos apenas na perspectiva sempre presente de modais epistêmicos, algo que, como já apontamos, não é unânime entre pesquisadores.

Os dados do PB foram particularmente esclarecedores no que se refere à determinação da orientação temporal de verbos modais, discutida no capítulo 4. Fomos capazes de identificar todos os morfemas que entram para a computação de cada possibilidade de orientação temporal, o que nos permitiu dispensar princípios pragmáticos e manter a semântica dos modais inalterada. Para explicar a impossibilidade de modais epistêmicos universais serem orientados ao futuro, propusemos, seguindo Giannakidou e Mari (2018), que modais epistêmicos universais entrariam em competição com o futuro, que seria a forma especializada de referência à necessidade epistêmica futura.

Na seção seguinte, apresentaremos algumas inconsistências deste trabalho e apontaremos questões em aberto para trabalhos futuros. 


\subsection{Questões para pesquisas futuras}

A primeira inconsistência em potencial desta pesquisa diz respeito à obtenção de dados. Como nosso objetivo desde o início era traçar um panorama da interação entre verbos modais, tempo e aspecto no PB, optamos por trabalhar com dados de introspecção. Embora a maior parte dos exemplos discutidos sejam bastante comuns na língua e tenham uma interpretação bastante clara, alguns julgamentos foram notadamente sutis. Esse é o caso de algumas orientações temporais mais complexas, como aquelas que chamamos de orientação de Futuro do Pretérito e orientação de Pretérito-mais-que-perfeito. Sentenças com o verbo poder, em sua leitura epistêmica, abaixo da negação também foram rejeitadas por alguns falantes que consultamos. Em trabalhos futuros, talvez seja proveitoso conduzir pesquisas experimentais para verificar a aceitabilidade desses exemplos.

A natureza panorâmica desta dissertação também levou à omissão de algumas interações modal-temporais bastante interessantes. Uma das omissões mais notáveis foi a de modais metafísicos ${ }^{1}$. A modalidade metafísica é particularmente desafiadora e divide pesquisadores. Alguns, como Abusch (2012) e Klecha (2016), propõem que seja possível modelar a modalidade metafísica a partir de uma base modal circunstancial. Outros, como Condoravdi (2002) e Ferreira (2018), assumem a existência de uma base modal metafísica. Outro desafio que a modalidade metafísica traz é a dificuldade em dicerní-la da modalidade epistêmica. Como Klecha (2016, pp. 36) aponta, a base modal metafísica ${ }^{2}$ é um superconjunto da base modal epistêmica, visto que o conjunto de proposições verdadeiras é um superconjunto das proposições conhecidas. Como consequência, a distinção entre modais metafísicos e modais epistêmicos é extremamente sutil. Essa sutileza foi utilizada por Werner (2006) e Klecha (2016) para propor que modais epistêmicos não poderiam ter orientação futura. De acordo com esses autores, sentenças com modais epistêmicos de força existencial orientados ao futuro seriam, na verdade, exemplos com modais metafísicos. Se esse for o caso, a restrição que discutimos no último capítulo diria respeito não à necessidade epistêmica, mas à necessidade metafísica, visto que leituras metafísicas, que são sempre orientadas ao futuro, também estão indisponíveis para modais de necessidade. Se adotarmos essa visão, teríamos que assumir que modais epistêmicos não podem de fato ter orientação futura.

Outra interação modal-temporal pouco explorada foi a interação entre o aspecto perfectivo e modais raiz. A morfologia de pretérito perfectivo parece bloquear orientações futuras, mesmo quando o prejacente do modal inclui um predicado eventivo. Não sabemos exatamente por que isso ocorre.

Quanto à continuação dessa pesquisa, um caminho natural seria estender a análise

\footnotetext{
${ }^{1}$ Veja Ferreira (2018) para uma análise da modalidade metafísica que utiliza como material empírico o PB.

${ }^{2} \mathrm{O}$ autor considera a base modal metafísica como uma forma especializada da base modal circunstancial.
} 
que fizemos sobre orientação temporal a verbos de atitude proposicional, como querer, acreditar, lamentar, etc. Esses verbos claramente impõem restrições às suas possibilidades de orientação temporal. Essa correlação inspirou o trabalho de Abusch (2004), que procurou descrever a composição sintática dos complementos desses verbos. A autora propôs a existência de duas classes de verbos alçamento no inglês: a classe I, composta por verbos que sempre têm orientação presente; e a classe II, cuja orientação é sujeita a maior variação ${ }^{3}$ :

\begin{tabular}{ll}
\hline classe I & classe II \\
\hline asserted (afirmou) & anticipated (antecipou) \\
believed (acreditou) & expected (esperou) \\
claimed (alegou) & forecast (previu) \\
confessed (confessou) & intended (pretendeu) \\
knew (soube) & meant (quis dizer) \\
reported (reportou) & planned (planejou) \\
said (disse) & predicted (previu) \\
thought (achou) & projected (projetou) \\
\hline
\end{tabular}

Quadro 5.1: Classificação de verbos de alçamento de acordo com sua orientação temporal (Abusch (2004))

A classificação proposta por Abusch (2004) suscita diversas questões: Esses verbos se comportam da mesma maneira no PB, ou sua orientação temporal está sujeita a variação translinguística? Seria possível reduzir a orientação temporal desses verbos à mesma restrição única que propusemos para verbos modais? O PB fornece alguma evidência adicional sobre a composição sintática dos complementos desses verbos? Essas são algumas das questões que pretendemos explorar em trabalhos futuros.

\footnotetext{
${ }^{3}$ Traduções nossas.
} 


\section{Bibliografia}

ABUSCH, D. On the temporal composition of infinitives. In: GUERON, J.; LECARME, J. (Ed.). The syntax of time. [S.l.]: MIT Press, 2004.

ABUSCH, D. Circumstantial and temporal dependence in counterfactual modals. Natural Language Semantics, Springer, v. 20, n. 3, p. 273-297, 2012.

BANERJEE, N. Trouble with attitudes and the future. In: CASCADILLA PROCEEDINGS PROJECT. 35th West Coast Conference on Formal Linguistics. [S.l.], 2018. p. $1-17$.

BHATT, R. Ability modals and their actuality entailments. WCCFL 17 Proceedings, CSLI Publications Stanford, CA, v. 17, p. 74-87, 1999.

CINQUE, G. Adverbs and functional heads: A cross-linguistic perspective. [S.l.]: Oxford University Press on Demand, 1999.

CONDORAVDI, C. Temporal interpretation of modals - modals for the present and for the past. In: The Construction of Meaning. [S.l.]: CSLI Publications, 2002. p. 59-88.

COPLEY, B. The semantics of the future. [S.l.]: Routledge, 2009.

DEAL, A. R. Modals without scales. Language, p. 559-585, 2011.

DEMIRDACHE, H.; URIBE-ETXEBARRIA, M. Morphosyntactic variation in the temporal construals of non-root modals. Romance Languages and Linguistic Theory 2008: Selected papers from 'Going Romance', 2010.

ENÇ, M. Tense and modality. 1996.

FERREIRA, M. The semantic ingredients of imperfectivity in progressives, habituals, and counterfactuals. Natural Language Semantics, Springer, v. 24, n. 4, p. 353-397, 2016.

FERREIRA, M. Notas de aula de curso de semântica intensional. Universidade de São Paulo, 2017.

FERREIRA, M. On the indexicality of portuguese past tenses. Journal of Semantics, Oxford University Press, v. 34, n. 4, p. 633-657, 2017.

FERREIRA, M. Estudos formais sobre a semantica nominal e verbal do portugues. Tese de Livre Docência — Universidade de São Paulo, São Paulo, 2018.

von FINTEL, K. X-Marked Desires. Comunicação oral durante o CIEL VI. Brasília, 2017. 
von FINTEL, K.; GILLIES, A. Cia leaks. Philosophical review, Duke University Press, v. 117, n. 1, p. 77-98, 2008.

von FINTEL, K.; HEIM, I. Lecture notes on intensional semantics. ms., Massachusetts Institute of Technology, 2002.

von FINTEL, K.; IATRIDOU, S. Epistemic containment. Linguistic Inquiry, MIT Press, v. 34, n. 2, p. 173-198, 2003.

von FINTEL, K.; IATRIDOU, S. How to say ought in foreign: The composition of weak necessity modals. In: Time and modality. [S.1.]: Springer, 2008. p. 115-141.

GIANNAKIDOU, A.; MARI, A. A two dimensional analysis of the future: modal adverbs and speaker's bias. In: ALONI, M.; FRANKE, M.; ROELOFSEN, F. (Ed.). Proceedings of the 19th Amsterdam Colloquium. [S.l.: s.n.], 2013. p. 115 - 122.

GIANNAKIDOU, A.; MARI, A. A unified analysis of the future as epistemic modality. Natural Language \& Linguistic Theory, Springer, v. 36, n. 1, p. 85-129, 2018.

GRICE, H. P. Logic and conversation. 1975, p. 41-58, 1975.

HACKL, M. On the semantics of 'ability attributions'. 1998.

HACQUARD, V. Aspects of modality. Tese (Doutorado) - Massachusetts Institute of Technology, 2006.

HACQUARD, V. On the interaction of aspect and modal auxiliaries. Linguistics and Philosophy, Springer, v. 32, n. 3, p. 279, 2009.

HACQUARD, V. On the event relativity of modal auxiliaries. Natural language semantics, Springer, v. 18, n. 1, p. 79-114, 2010.

HOCKETT, C. F.; ALTMANN, S. A. A note on design features. Animal communication: Techniques of study and results of research, Indiana University Press Bloomington, IL, p. 61-72, 1968.

IATRIDOU, S.; SICHEL, I. Negative dps, a-movement, and scope diminishment. Linguistic Inquiry, MIT press, v. 42, n. 4, p. 595-629, 2011.

KLECHA, P. Bridging the divide: Scalarity and modality. Tese (Doutorado) - University of Chicago, Division of the Humanities, Department of Linguistics, 2014.

KLECHA, P. Modality and embedded temporal operators. Semantics and Pragmatics, v. 9, p. 9-1, 2016 .

KLEIN, W. Time in language. [S.l.]: Routledge, 2013.

KRATZER, A. The notional category of modality. Words, Worlds, and Contexts, p. 38-74, 1981.

KRATZER, A. Modality. Semantics: An international handbook of contemporary research, ed. by Arnim von Stechow and Dieter Wunderlich, 639-50. [S.1.]: Berlin: De Gruyter, 1991. 
KRATZER, A. More structural analogies between pronouns and tenses. In: Semantics and linguistic theory. [S.l.: s.n.], 1998. v. 8, p. 92-110.

KRATZER, A. Modals and conditionals: New and revised perspectives. [S.1.]: Oxford University Press, 2012.

KRATZER, A. Modality for the 21st century. In: 19th International Congress of Linguists. [S.l.: s.n.], 2013. p. 181-201.

KRATZER, A.; HEIM, I. Semantics in Generative Grammar. [S.1.]: Oxford: Blackwell, 1998.

KRATZER, A.; PIRES DE OLIVEIRA, R.; PESSOTTO, A. L. Talking about modality: an interview with Angelika Kratzer. ReVEL, especial, n. 8, 2014.

LACA, B. Epistemic modality and perfect morphology in Spanish and French. In: GUENTCHEVA, Z. (Ed.). [S.l.]: Mouton/de Gruyter, 2018. p. 103-130.

LACA, B. When Perfects raise: Perfect Modals across French and Spanish Varieties. Comunicação oral durante o CITAM I. Rio de Janeiro, 2018.

LUNGUINHO, M. V. Sobre a concordância modal em português. Cadernos de Linguagem e Sociedade, v. 11, n. 2, p. 117-140, 2010.

LUNGUINHO, M. V. On the acquisition of root and epistemic modals in Brazilian Portuguese. ReVEL, n. 8, 2014.

MARI, A. French future: Exploring the future ratification hypothesis. Journal of French Language Studies, Cambridge University Press, v. 26, n. 3, p. 353-378, 2016.

MATTHEWSON, L. On the (non)-future orientation of modals. In: Proceedings of sinn und bedeutung. [S.1.: s.n.], 2012. v. 16, p. 431-446.

MATTHEWSON, L. Gitksan modals. International Journal of American Linguistics, University of Chicago Press Chicago, IL, v. 79, n. 3, p. 349-394, 2013.

MATTHEWSON, L.; DAVIS, H.; RULLMANN, H. Evidentials as epistemic modals: Evidence from st'át'imcets. Linguistic variation yearbook, John Benjamins Publishing Company, v. 7, n. 1, p. 201-254, 2007.

PARTEE, B. H. Some structural analogies between tenses and pronouns in english. The Journal of Philosophy, JSTOR, v. 70, n. 18, p. 601-609, 1973.

PERCUS, O. Constraints on some other variables in syntax. Natural language semantics, Springer, v. 8, n. 3, p. 173-229, 2000.

PESSOTO, A. L. S. Força e evidência: Uma análise teórico experimental da semântica de 'pode', 'deve' e 'tem que'. 2015.

PESSOTTO, A. L. 'pode' e 'podia': Uma proposta semântico-pragmática. Revista da ABRALIN, v. 10, n. 2, 2011.

PESSOTTO, A. L. Epistemic and Gradable Modality in Brazilian Portuguese: a comparative analysis of 'poder', 'dever' and 'ter que'. [S.l.]: ReVEL, 2014. 
PIRES DE OLIVEIRA, R.; PESSOTTO, A. L. Wishing it were: 'podia' and the implicature of desire in Brazilian Portuguese. In: LIMA, S. (Ed.). [S.l.: s.n.], 2010. v. 5.

PIRES DE OLIVEIRA, R.; SCARDUELLI, J. A. Explicando as diferenças semânticas entre 'ter que' e 'dever': uma proposta em semântica de mundos possíveis. ALFA: Revista de Linguística, v. 52, n. 1, 2009.

PORTNER, P. Modality. [S.1.]: Oxford University Press, 2009.

PORTNER, P.; RUBINSTEIN, A. Extreme and non-extreme deontic modals. Deontic modals, p. 256-282, 2016.

RULLMANN, H.; MATTHEWSON, L. Towards a theory of modal-temporal interaction. Language, Linguistic Society of America, v. 94, n. 2, p. 281-331, 2018.

von STECHOW, A. Tenses in compositional semantics. The expression of time, $\mathrm{p}$. 129-166, 2009.

STOWELL, T. Tense and modals. In: GUÉRON, J.; LECARME, J. (Ed.). The syntax of time. [S.l.]: MIT Press, 2004.

THOMASON, R. H. Combinations of tense and modality. In: Handbook of philosophical logic. [S.l.]: Springer, 1984. p. 135-165.

TRAVIS, L. D. Parameters and effects of word order variation. [S.l.]: MIT Press, 1984.

von FINTEL, K. .; GILLIES, A. S. Epistemic modality for dummies. URL http://mit. edu/fintel/www/fintel-gillies-ose2. pdf. Ms, MIT and University of Michigan, 2006.

WERNER, T. Future and non-future modal sentences. Natural Language Semantics, Springer, v. 14, n. 3, p. 235-255, 2006.

WERNER, T. A. Deducing the future and distinguishing the past: Temporal interpretation in modal sentences in English. Tese (Doutorado) - Rutgers University, 2003.

WINTER, Y. Elements of formal semantics: An introduction to the mathematical theory of meaning in natural language. [S.l.]: Edinburgh University Press, 2016.

WURMBRAND, S. Modal verbs must be raising verbs. In: Proceedings of the 18 th West coast conference on formal linguistics. [S.l.: s.n.], 1999. p. 599-612.

WURMBRAND, S. Tense and aspect in english infinitives. Linguistic Inquiry, MIT Press, 2014.

ZAGONA, K. On the syntactic features of epistemic and root modals. Coreference, modality and focus: studies on the syntax/semantics interface, p. 221-236, 2007.

ZAGONA, K. Phasing in modals: Phases and the epistemic/root distinction. In: Time and Modality. [S.l.]: Springer, 2008. p. 273-291. 